\title{
46. RIFT-TO-DRIFT HISTORY OF THE WOMBAT PLATEAU, NORTHWEST AUSTRALIA: TRIASSIC TO TERTIARY LEG 122 RESULTS ${ }^{1}$
}

\author{
Ulrich von Rad, ${ }^{2}$ Neville F. Exon, ${ }^{3}$ and Bilal U. Haq ${ }^{4}$
}

\begin{abstract}
During the early Mesozoic, northwest Australia was a passive margin of eastern Gondwana facing the southern Tethys sea. A transect of four Ocean Drilling Program sites $(759,760,761$, and 764) across the Wombat Plateau, a small plateau north of the Exmouth Plateau, and existing high-quality seismic data have enabled the syn-rift and post-rift structural and paleoenvironmental evolution of eastern Gondwana to be evaluated.

The composite 900-m-thick Upper Triassic syn-rift succession consists of several shallowing-upward cycles of fluviodeltaic siliciclastics with carbonate intercalations of Carnian/Norian age containing the oldest documented nannofossil assemblages. They are overlain by a Rhaetian carbonate platform of lagoonal and reefal facies (keep-up carbonate system). Overlying a global sequence boundary at the base of the Rhaetian (215 Ma, "Rhaetian transgression"'), several shallowing-upward cycles indicate shallow-subtidal to intertidal environments (Site 761). Typical reef development, observed at the platform margin (Site 764), ended abruptly with another sequence boundary ( $211 \mathrm{Ma}$ ) during a eustatic sea-level fall, followed by a latest Rhaetian-Liassic transgression. This facies development correlates with coeval facies changes in the western Tethys (Alps).

During the Jurassic, Wombat Plateau underwent early-rift volcanism (early Liassic) and a major block-faulting episode (Callovian/Oxfordian) resulting in uplift, rift flank tilting, subaerial erosion of the horst, and the formation of a "post-rift unconformity."

Formation of the incipient Indian Ocean at Argo Abyssal Plain followed during Late Jurassic breakup of eastern Gondwana. This coincided with rapid subsidence of the Wombat Plateau and a Tithonian-Berriasian transgression. Hemipelagic sedimentation of the "juvenile-ocean" stage is characterized by a condensed section of terrigenous littoral sands and belemnite-rich sandy muds. Calcisphere-nannofossil chalks indicate a stress environment and bentonites early post-breakup volcanism. During the Albian to Cenozoic, eupelagic sedimentation followed with declining subsidence and sedimentation rates ("mature-ocean stage").

The Mesozoic depositional sequences recovered from Wombat Plateau are strongly affected by tectonics during the early-rift stage and rift-drift transition (rift-related uplift, post-rift unconformity, and non-uniform differential subsidence). Climatic changes, such as the northward drift of the northwest Australian area to subtropical latitudes during the Rhaetian, favored the buildup of reefal carbonates. Cyclic siliciclastic sediment input was especially important during rapid fluviodeltaic sedimentation in the Carnian/Norian. However, the discovery of four sequence boundaries in the Late Triassic (" 224 ," " 220 ," " 215 ," and " 211 " Ma), which are little disturbed by tectonics and correlate with coeval events in western Tethys, suggests that eustasy played a significant role in generating the Wombat Plateau depositional sequences.
\end{abstract}

\section{INTRODUCTION}

Before Ocean Drilling Program (ODP) Legs 122 and 123 , the early Mesozoic tectonic and paleoceanographic history of the world's oceans received little attention through scientific drilling activity. The stratigraphic records of old rifted margins, especially sediment-starved margins like the Exmouth Plateau off northwest Australia, contain important clues about the thermal and structural processes that lead to rifting and continental breakup, and the concomitant paleoenvironmental changes, prior to and after the formation of young ocean basins. Leg 122 was the first leg of the Indian Ocean drilling program to core this old stratigraphic record since JOIDES Resolution drilled the Galicia margin off Spain during Leg 103 (Boillot, Winterer, et al., 1987).

During Leg 122 we drilled a transect of four sites $(759,760$, 761 , and 764 ) across the Wombat Plateau, a small subplateau

\footnotetext{
${ }^{1}$ von Rad, U., Haq, B. U., et al., 1992. Proc. ODP, Sci. Results, 122: College Station, TX (Ocean Drilling Program).

2 Bundesanstalt für Geowissenschaften und Rohstoffe, Postfach 510153, D-3000 Hannover 51, Federal Republic of Germany.

${ }^{3}$ Bureau of Mineral Resources, Geology and Geophysics, P.O. Box 378, Canberra, ACT 2601, Australia.

${ }_{4}^{4}$ Marine Geology and Geophysics, National Science Foundation, $1800 \mathrm{G}$ Street, NW, Washington, DC 20550, U.S.A.
}

in water depths of about $2000 \mathrm{~m}$, separated from the northern Exmouth Plateau by the deep "Wombat half-graben" (Figs. 1 and 2; for a description of the structural and depositional setting of the northern Exmouth Plateau see "Tethyan Evolution," section, this chapter; and Exon et al., this volume, chapter 1). Within easy reach of the drill bit, this margin provided an opportunity:

1. To study the Triassic to Early Cretaceous biostratigraphic and paleoenvironmental evolution of the eastern Tethys ocean off northeastern Gondwana in a well-preserved, Southern Hemisphere, mid- to low-latitudinal setting;

2 . To investigate the tectonic and magmatic syn-rift history of the northwest Australian margin;

3. To study the Jurassic rift-drift transition and the Early Cretaceous juvenile-ocean phase (i.e., the development from Neo-Tethys to the birth of the proto-Indian Ocean); and

4. To test sequence-stratigraphic and eustatic models in order to discern and understand the effects of vertical tectonics, sediment supply, climate, and global sea-level changes (Haq et al., 1987, 1988; Wilgus et al., 1988).

The Wombat Plateau (Leg 122)-Argo Abyssal Plain (Leg 123, Site 765) transect represents a complete cross-section across an old, sediment-starved, passive continental margin and the adjacent deep ocean basin (Fig. 2; von Rad et al., 


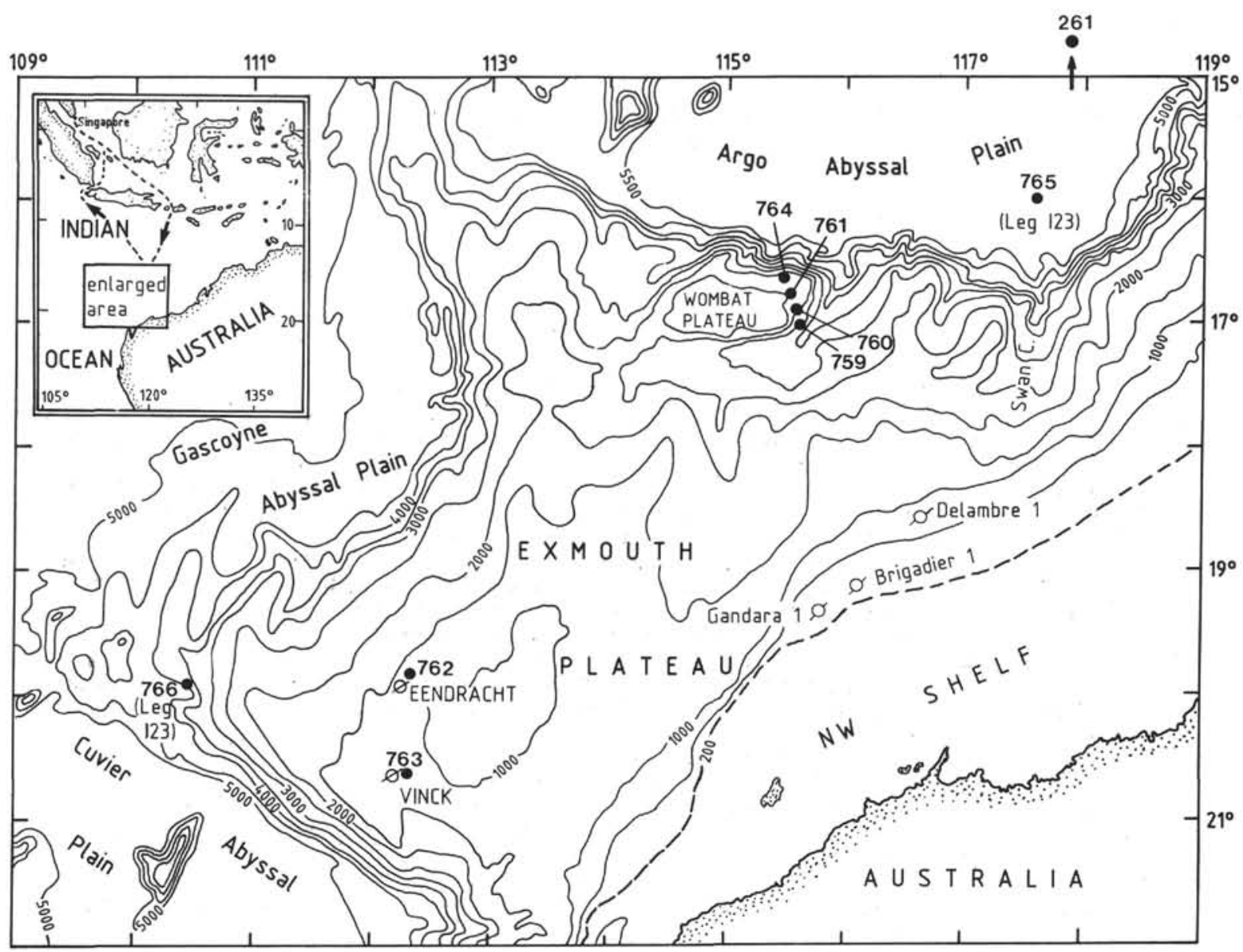

Figure 1. Location map of Sites 759-766 (Legs 122 and 123) on the Exmouth Plateau and vicinity. Selected petroleum exploration wells and DSDP Site 261 are also shown. Inset shows route of the JOIDES Resolution during Leg 122 . The ocean-continent boundary coincides roughly with the $3000-\mathrm{m}$ contour along the escarpment between the Exmouth Plateau (continental crust) and the three surrounding deep-ocean basins.

1989). The post-breakup (Cretaceous to Cenozoic) sediment section of this margin is sediment-starved because of low relief of northwest Australia and generally arid climate. Drilling tectonically less-deformed margin/ocean basin transects is important in understanding the early tectonic and magmatic evolution of passive continental margins and their paleoenvironmental evolution. This approach should be augmented by the study of the Mesozoic history of eastern Tethys and its southern margins in suture zones of deformed young Eurasian mountain belts such as Timor, Papua New Guinea, Burma, or the Tethys Himalaya (Gradstein et al., 1989b).

The Triassic intracratonic early-rift stage can be studied effectively in the Wombat Plateau sites. This sequence is capped by a major regional "post-rift unconformity" spanning the Callovian to Oxfordian interval which is overlain by Lower Cretaceous, hemipelagic, "juvenile ocean"-stage sediments and by Upper Cretaceous to Cenozoic eupelagic "mature ocean"-stage sediments which also can be studied in the nearby Argo Abyssal Plain Site 765 (Fig. 2).

In this synthesis, we summarize the most important tectonic and paleoenvironmental results of the four Wombat Plateau sites. We attempt to reconstruct the 230-m.y. history of this margin using a sequence-stratigraphic approach and separating tectonic factors (e.g., rifting events) from eustatic sea-level fluctuations. We quote freely from the sedimentological and structural papers published in this volume (especially Dumont; Ito et al.; Röhl et al.; Sarti et al., all this volume). For paleon- tological syntheses see Brenner et al. (Triassic biostratigraphy), Bralower and Siesser (Cretaceous nannofossils), and Brenner (Early Cretaceous palynomorphs, chapter 31 ). In this paper we consistently use the time scale of Haq et al. (1987).

\section{TETHYAN EVOLUTION OF THE NORTHWEST AUSTRALIAN MARGIN}

The Neo-Tethys ocean (sensu Sengör, 1985, i.e., the classical Tethys sea or "Tethys III" sensu Audley-Charles, 1988) opened in the Late Triassic to Jurassic between Gondwana and "Cimmeria" (South Tibet-Burma-Malaya-Sumatra), while the Permian/Early Triassic Palaeo-Tethys ("Tethys II") was progressively being closed between Cimmeria and Laurasia (Fig. 3).

During the Late Jurassic, Gondwana was in turn split into western Gondwana (South America, Africa) and eastern Gondwana (Greater India, Madagascar, Antarctica, Australia) with a proto-oceanic rift (Weddell Sea-Somali Basin) wedged in between (Fig. 3). Northwest Australia and the Tethys Himalaya (northern part of "Greater India") formed adjacent sedimentary environments along the northern shore of the East Gondwanan continent (Gradstein et al., 1989b). During the latest Jurassic to Early Cretaceous, about 140-120 Ma, eastern Gondwana started to break up: the Indian Plate broke apart from the still contiguous Australian-Antarctica continent. Other continental terranes, such as the South Tibet/ Lhasa block, the Sikuleh-Natal fragment, the Mount Victoria 

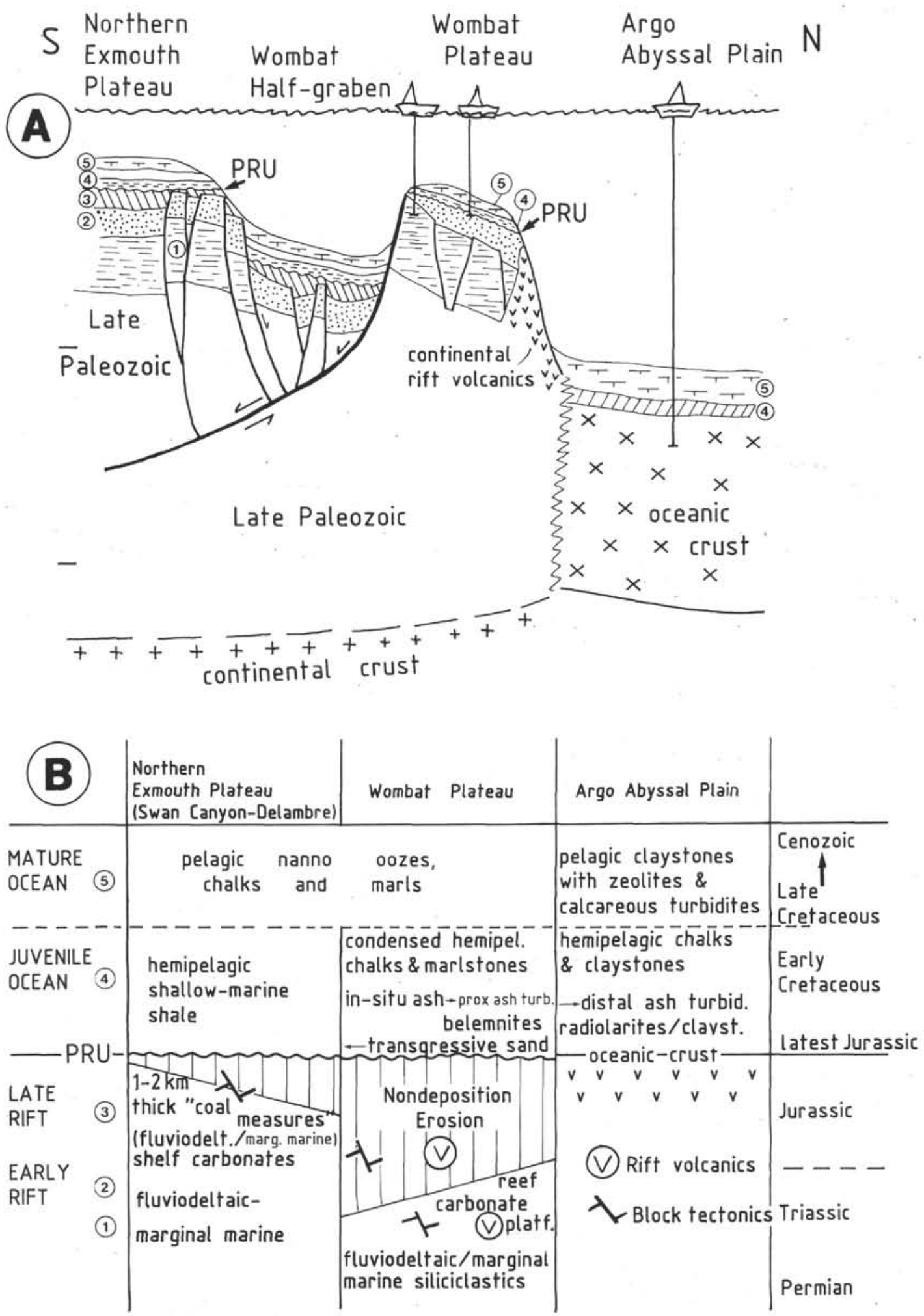

Figure 2. A. Schematic north-south cross-section over northern Exmouth Plateau-Wombat Plateau-Argo Abyssal Plain. Note the marked post-rift unconformity (PRU), underlain by block-faulted Triassic (-Jurassic) sediments and overlain by a thin cover of post-breakup sediments-a typical sediment-starved passive margin.. $1=$ Early-rift (Carnian) fluviodeltaic sediments; 2 = early-rift (Norian-Rhaetian fluviodeltaic sediments/shelf carbonates/reefs; 3 $=$ late-rift (Jurassic) fluviodeltaic sediments/shelf carbonates; 4 = juvenile-ocean (latest Jurassic-Early Cretaceous) marine claystones, marls, etc.; 5 = mature-ocean (Late Cretaceous to Cenozoic) chalks and oozes. Note continental rift volcanics (latest Triassic/early Liassic) and possible syn-breakup (?early Neocomian) volcanics at oceancontinent boundary. B. Schematic stratigraphic development of the northern Exmouth Plateau continental margin, an example of a very old, sediment-starved rifted margin. Symbols and numbers as for Figure 2A. 


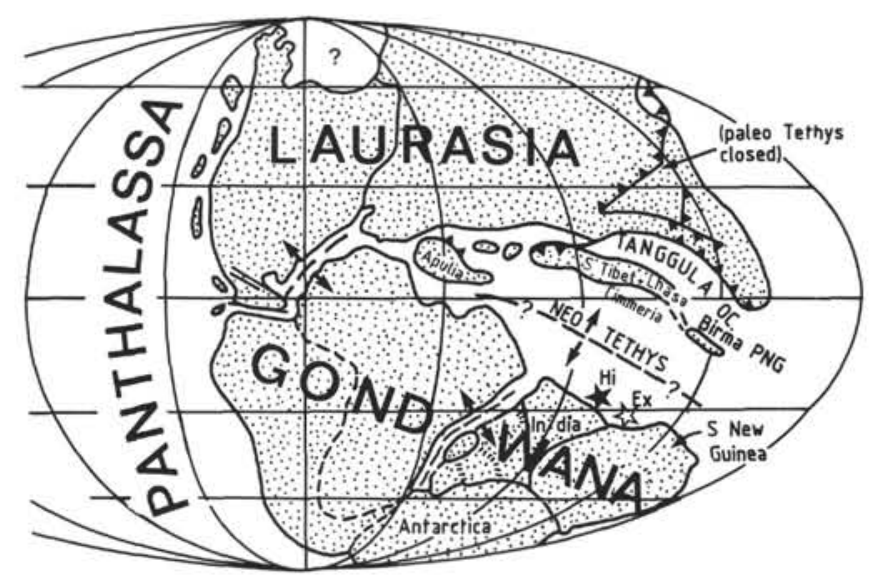

Figure 3. Reconstruction of continents and oceans during the Middle to Late Jurassic (150 Ma). Note that Exmouth Plateau (Ex) and Tethys Himalaya $(\mathrm{Hi})$ are adjacent southern Tethyan margins located off northeastern Gondwana (modified after Sengör, 1985, and other sources; from von Rad et al., 1989).

Land block, and Timor and the Papua New Guinea microplates also separated from eastern Gondwana during the Jurassic (Sengör, 1985; Sengör et al., 1988).

Görür and Sengör (this volume) stress that the northwest Australian margin was the site of repeated rifting, whereby successive continental terranes were ripped off the East Gondwanan continent and carried northward by spreading oceans to collide with the accreting Asian continent. One of the small Gondwanan fragments that rifted off the northwestern Australian continent in the Neocomian was the SikulehNatal fragment (with arc volcanics), which collided with the rest of Sumatra in the Late Cretaceous. Görür and Sengör (this volume) speculate that the Mount Victoria Land block, which is now an integral part of Burma, rifted (together with the South Tibet-Central Burma block) away from northwest Australia during the latest Triassic to Middle Jurassic.

The first breakup for which good data are available occurred during the Late Jurassic between fragments of the northern Exmouth Plateaun on one side and an unknown (lost) continental fragment on the other. This "Argo Landmass" might correspond to Mount Victoria Land of Burma or the Lhasa block of southern Tibet (Figs. 17 and 18). The breakup between the central Exmouth Plateau and "Greater India," forming the Gascoyne/Cuvier abyssal plains, started during the late Valanginian to early Hauterivian (Ludden, Gradstein, et al., 1990; Boyd et al., this volume). At the southwest Australian margin (Perth Basin) seafloor spreading did not start before the late Hauterivian (magnetochron M4 = ca. 117 Ma; Markl, 1978).

Thus, during the Triassic to Jurassic, the Exmouth Plateau was part of a South Tethyan passive margin at the northern border of the East Gondwanan continent; this margin was in the vicinity of the Tethys Himalaya-South Tibet depositional area (northeastern rim of "Greater India") to the west and of Timor-Burma-Thailand-Malaya to the northeast (see also Dewey, 1988; Audley-Charles, 1988; Gradstein et al., 1989b). The demise of Neo-Tethys during the Cretaceous to Paleogene was a compensation for the Late Jurassic disassembly of Gondwana and the opening of the central Atlantic and Indian oceans (Şengör, 1985; Sengör et al., 1988).

\section{STRUCTURAL AND DEPOSITIONAL SETTING OF NORTHERN EXMOUTH PLATEAU}

The northern Exmouth Plateau is a north-facing part of the Australian continental margin, with the oceanic crust of the
Argo Abyssal Plain bordering it immediately toward the north (Fig. 4A). The Exmouth Plateau consists of thinned, tilted, and deeply subsided continental crust, with a Phanerozoic sedimentary sequence in excess of $10 \mathrm{~km}$ thick. The known sequences along the northern margin range in age from Triassic to Neogene. The margin is cut by major northeasteast-trending, steeply dipping faults into a number of horsts, grabens, and half-grabens: the major horsts are the Wombat Plateau, the Echidna Spur, and the Emu Spur (Fig. 4A). A line drawing, from regional seismic lines along the margin (Fig. 4B) illustrates the regional geology. In the far east, under the Pilbara Shelf, there are older rocks that are not known from the Exmouth Plateau. These include the ancient continental basement of the Pilbara Block and pre-Permian and Permian detrital sediments which are overlain by Triassic sediments that can be traced westward along the Exmouth Plateau margin. Lower Triassic strata are not known from the plateau, but the shallow-marine, Lower Triassic Locker Shale is probably present at depth.

The northern Exmouth Plateau has been studied by academic institutions, jointly by the Australian Bureau of Mineral Resources (BMR) and the German Bundesanstalt für Geowissenschaften und Rohstoffe (BGR), and by commercial petroleum exploration companies. Key studies carried out before ODP drilling fall into the following categories.

1. Studies of spreading history of the Argo Abyssal Plain using marine magnetic anomalies calibrated by Deep Sea Drilling Project (DSDP) Site 261 results (Falvey, 1974; Veevers, Heirtzler, et al., 1974; Markl, 1978; Larson, 1975; Heirtzler et al., 1978; Fullerton et al., 1989). These led to the view that seafloor spreading formed the Argo Abyssal Plain in the Callovian to Oxfordian.

2. BMR scientists in 1974-1978 used regional seismic profiles and well ties to suggest that the northern Exmouth Plateau had thick Triassic sedimentary sequences under a Callovian "E"' unconformity (Willcox and Exon, 1976; Exon and Willcox, 1978, 1980).

3. BGR and BMR studies in 1979-1983 used new seismic, dredge, and core information to show that the " $E$ " unconformity was generally underlain by thick Jurassic sedimentary sequences and that Early Jurassic volcanics were present on the northern Wombat Plateau (von Stackelberg et al., 1980; Exon et al., 1982; von Rad and Exon, 1983).

4. BMR geologists, in 1986-1988, used new dredge and multichannel seismic information to refine the earlier ideas and help plan ODP drilling (Exon et al., 1988; von Rad et al., 1990).

5. Geophysical Services International carried out a multichannel seismic survey of the deep-water areas south of the northern Exmouth Plateau margin in 1976. The data are now in the public domain and show thick Triassic and Jurassic sequences beneath the Callovian-Oxfordian post-rift unconformity and the importance of steeply dipping northeasttrending faults. Three petroleum exploration company wells were drilled in deep water in the southern part of the northern margin (Fig. 1): Hudbay Gandara No. 1, Woodside Brigadier No. 1, and Woodside Delambre No. 1 (Fig. 5). These wells indicate that there are thick Jurassic sequences beneath the post-rift ("E") unconformity.

There has been a steady advance of ideas on the evolution of the northern margin over the last 20 years. The previous age estimates of the formation of Argo Abyssal Plain were based on magnetic surveys and DSDP Leg 27, Site 261. The general nature of the northern Exmouth Plateau itself, with Mesozoic sediments under a major unconformity, was clear after the 


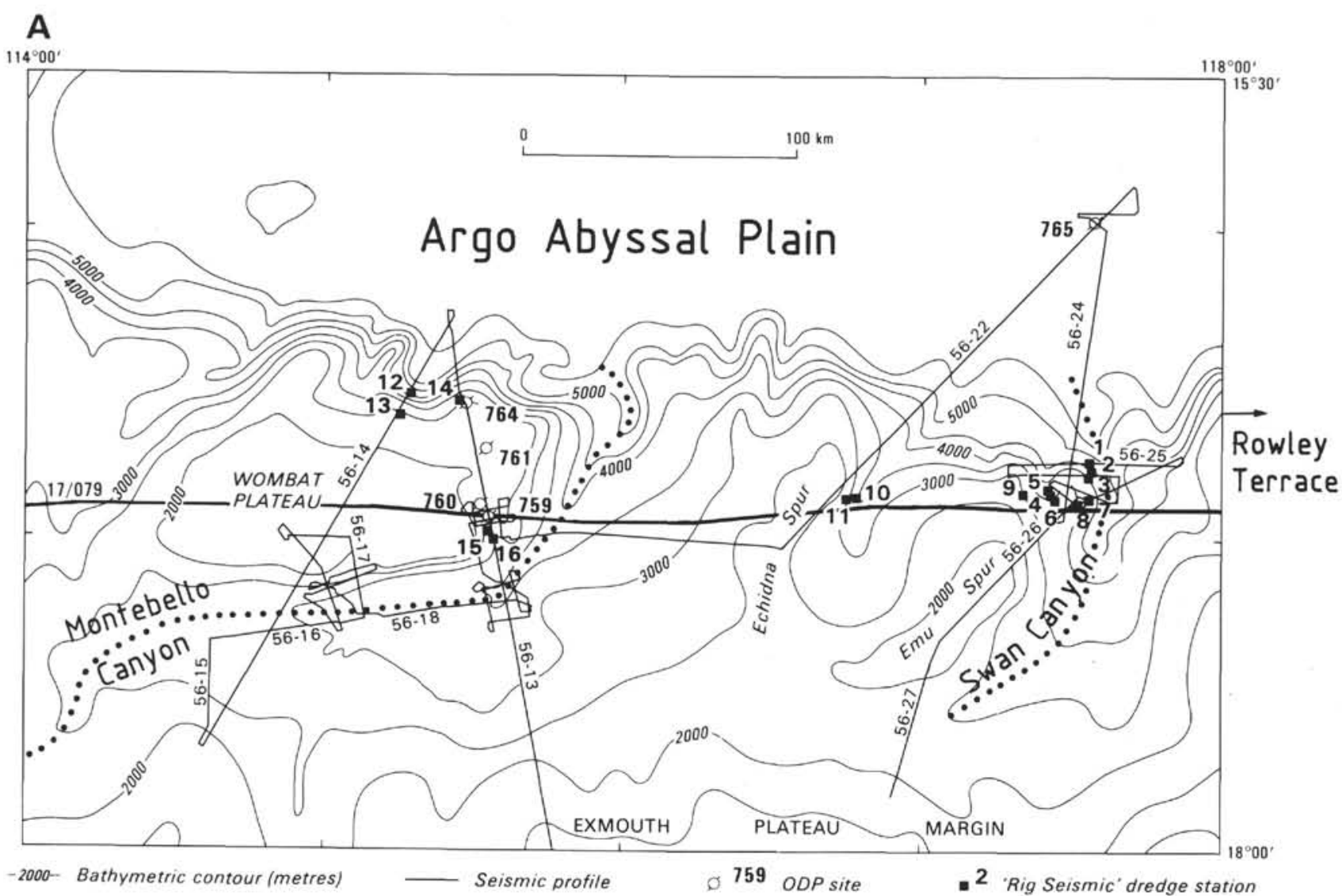

B

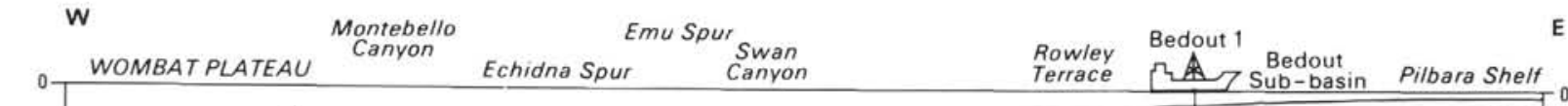
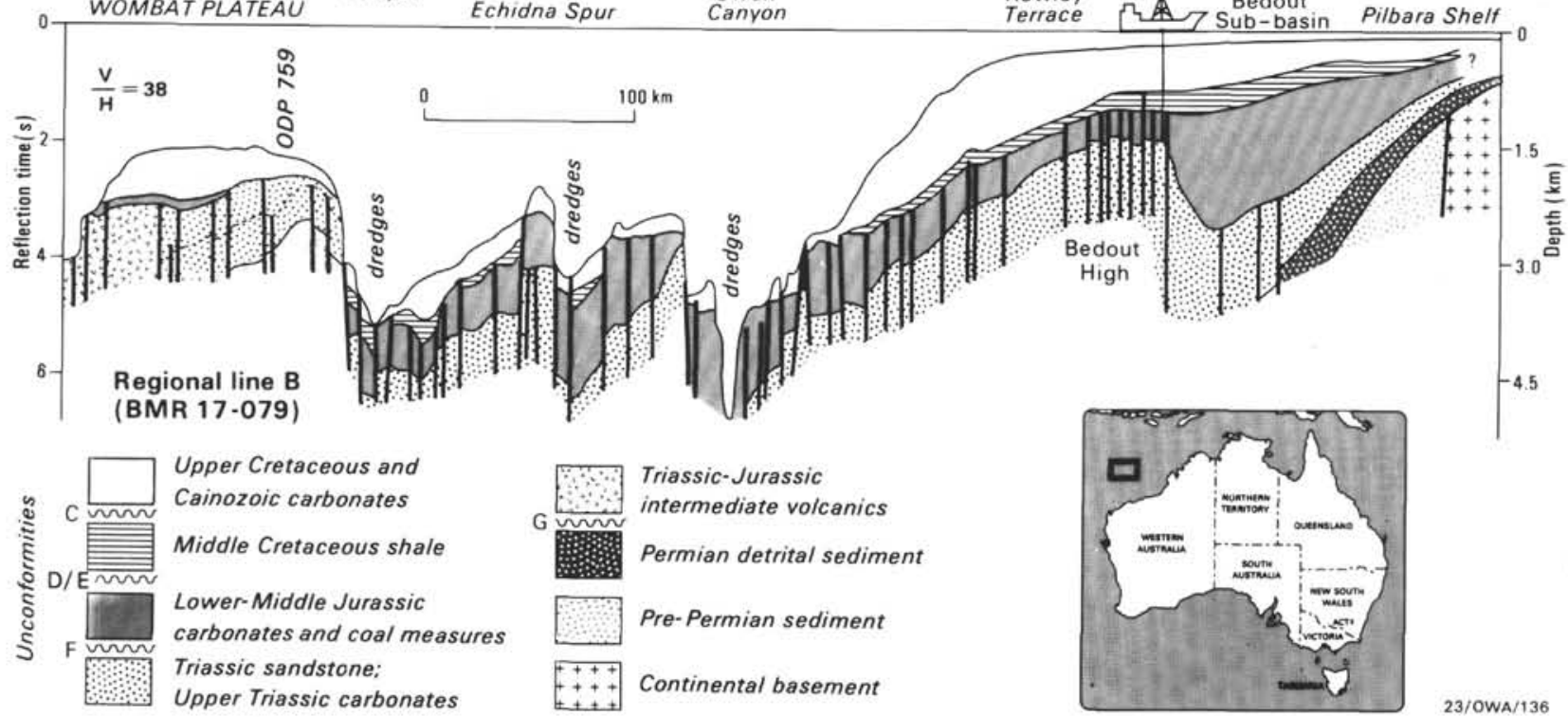

23/OWA/136

Figure 4. Northern Exmouth Plateau margin (after von Rad et al., 1990) A. General map showing Rig Seismic profiles and dredge sites, and ODP drill holes. Dotted lines = canyon axes. B. Schematic east-west profile from the Pilbara Shelf across the northern margin of the Exmouth Plateau. Western part based on BMR seismic profile $17 / 079$ (see Fig. 4A). Note westward tilt of fault blocks (Emu Spur; Echidna Spur; Wombat Plateau, which is also tilted northward; see Fig. 6). 


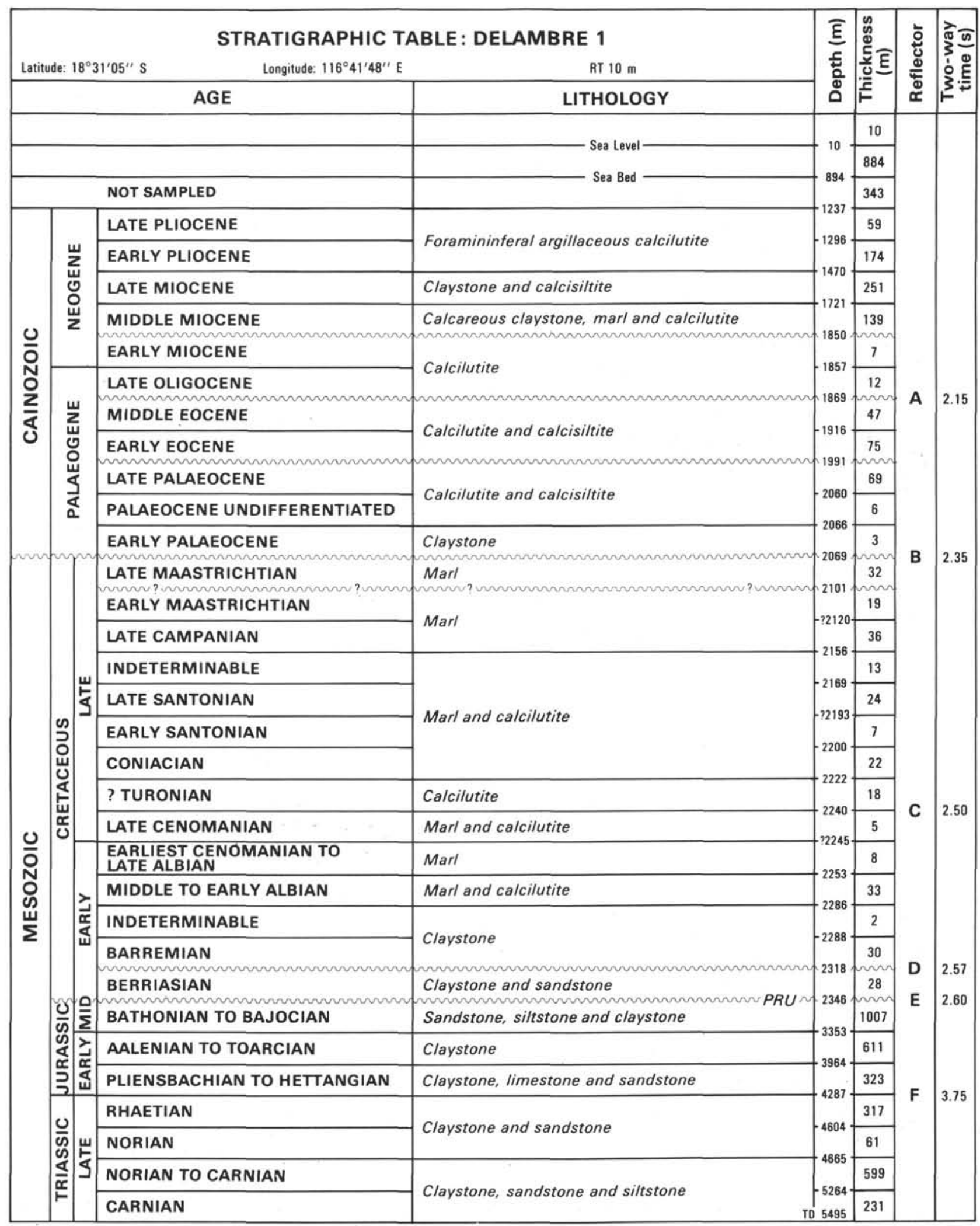

Figure 5. Lithologic and stratigraphic log of the Woodside Delambre No. 1 well (courtesy of Woodside Offshore Petroleum, Ltd). For location see Figure 1 (location $18^{\circ} 31.1^{\prime} \mathrm{S}, 116^{\circ} 41.8^{\prime} \mathrm{E}$; water depth $894 \mathrm{~m}$ ). Depth is in meters below rig floor. Note the 2-km-thick Jurassic late-rift siliciclastic sediments overlain by a post-rift unconformity (PRU) of Middle Jurassic age, and capped by thin, transgressive Berriasian sediments. A-F = seismic reflectors after Exon and Willcox (1978). 
first major review of seismic data (Willcox and Exon, 1976). Dredging showed that either Jurassic or Triassic sediments underlie the " $E$ " unconformity in different places.

Although the general structural and stratigraphic setting of the northern Exmouth Plateau margin was fairly well understood before ODP drilling, the Wombat Plateau drill sites yielded a number of unexpected premiums. These include the discovery of hitherto unknown Rhaetian reefs, the complete lack of a Jurassic section on the Wombat Plateau, and the discovery of a spectacular Berriasian transgressive sequence overlying the main post-rift unconformity.

The known sequence from the northern plateau is summarized in Figure 4B. Of special interest to our discussion is the stratigraphy of Woodside Delambre No. 1 well, the nearest commercial petroleum exploration well, located 200 km south-southwest of Site 759 (Fig. 5). The Late Triassic sequence is more than $1000 \mathrm{~m}$ thick and present in all seismic profiles. It is dominantly fluviodeltaic sandstone, siltstone, and mudstone derived from the south, but dredge and drill results show that shelf carbonates are developed in places along the outer margin, especially in the Rhaetian. In most of the area the Triassic sequence is overlain, at the " $F$ " unconformity of Exon and Willcox (1980), by a lower to middle Jurassic shallow-marine and paralic, 1000 - to 2000 m-thick "coal measure sequence" consisting of mudstone, siltstone, sandstone, and shallow-marine carbonates (Fig. 5). Jurassic rocks are absent from the uplifted eastern Wombat Plateau drilled during Leg 122. However, the east-west seismic profile 17/079 (Fig. 4B) indicates a general westward dip of the lower Mesozoic strata in all fault blocks between Swan Canyon and Wombat Plateau. Therefore it is possible that Jurassic strata are present below the western part of the plateau. Shallow-water carbonates dredged from the northeastern escarpment of Wombat Plateau were originally dated as Sinemurian/Pliensbachian (Quilty, 1981; Zobel in von Stackelberg et al., 1980), but are now considered to be mainly of Rhaetian age (with some probably RhaetoLiassic) by Kristan-Tollmann and Gramann (this volume), who provide a detailed study of the foraminifers, echinoderms, and ostracodes.

Although rift-related faulting occurred in several phases during the Permian, Triassic, and Jurassic, the generally uniform thickness of the Triassic and Jurassic sequences suggests that the major block-faulting event occurred after the Middle Jurassic. The vertical movement on the faults bounding the major blocks exceeds $1000 \mathrm{~m}$ in places (Fig. 4B). A period of uplift and erosion in the Late Jurassic is documented by the major angular post-rift " $E$ " unconformity (Figs. 4B, 5). The minimum stratigraphic extent of the hiatus on the northwest Australian margin is early Oxfordian (Woodside Corporation, unpubl. data), but in many areas the entire Upper Jurassic sequence is missing. We believe that the absence of the Jurassic sequence on the eastern Wombat Plateau is a result of Callovian-Oxfordian uplift and subsequent erosion (Williamson, this volume), rather than of subsidence and nondeposition during the Jurassic. This " $E$ " unconformity (Oxfordian) has been called "breakup unconformity," but we prefer the term "post-rift unconformity" (PRU), since the breakup between the northern edge of the plateau and Argo Abyssal Plain occurred somewhat later, during the Oxfordian times (155 $\pm 3 \mathrm{Ma}$; Ludden and Dionne, in press).

A Tithonian/Berriasian transgression is documented in the Delambre No. 1 well (Fig. 5) at Site 761 and possibly at Site 760. The Cretaceous sequence generally starts with mudstones and marls but gives way to calcilutites and chalks in the Turonian. A post-Berriasian " $D$ " unconformity is documented in Delambre No. 1 well (Fig. 5), and the Turonian change from marls to limestones gives rise to the regional " $\mathrm{C}$ " seismic reflector. The Cretaceous sequence is rarely thicker than $200 \mathrm{~m}$, and documents the change from a juvenile ocean to a mature ocean. The northern Exmouth Plateau margin subsided rapidly to bathyal depths in the Early Cretaceous, whereas shallow-water sedimentation characterizes the Australian Northwest Shelf. The Tertiary sequence on the northern Exmouth Plateau consists of thin bathyal chalks and oozes, whereas the Northwest Shelf has a Paleogene sequence about $200 \mathrm{~m}$ thick of outer shelf claystone, calcilutite and calcisiltite, and a 1000 -m-thick seaward-prograding Neogene sequence of calcarenites, calcisiltites, and calcilutites (Figs. 4B, 5). The " $\mathrm{B}$ " unconformity encompasses the Cretaceous/ Tertiary boundary, and the "A" unconformity is of early Oligocene age (Fig. 5).

According to our seismic and drilling results, all strata underlying the erosive post-rift unconformity ("E") on the eastern Wombat Plateau are of Triassic age (Fig. 6). Sites 759, 760, 761, and 764 were drilled to recover a composite Late Triassic syn-rift to Cretaceous/Cenozoic post-rift record of sediments. The oldest sediments recovered are of middle Carnian (ca. $227 \mathrm{Ma}$ ) age. The Wombat Plateau area experienced various Late Triassic rift phases. During the Jurassic (probably Callovian to Oxfordian) the block was uplifted above sea level and the horst subsequently eroded. During the Tithonian/Berriasian, thermal subsidence followed the breakup of the Argo Abyssal Plain. This resulted in the transgression of the sea and in the deposition of a thin veneer of Cretaceous and Cenozoic hemipelagic to eupelagic sediments (see also Fig. 2D, -E).

\section{WOMBAT PLATEAU SEQUENCE STRATIGRAPHY}

The stratigraphic results of the four Wombat Plateau Sites (759, 760, 761, and 764) are described in Haq, von Rad, O'Connell, et al. (1990). A summary is in the "Principal Results" and "Summary and Conclusions" sections of the site chapters. Plateau sites were chosen to recover a stacked section, younger to the north, of the older Mesozoic (Carnian to Rhaetian) syn-rift record and the overlying blanket of Lower Cretaceous to Cenozoic post-rift sediments (Fig. 6). An additional objective was to record sea-level fluctuations in order to test the eustatic models (Haq et al., 1987).

We have summarized the stratigraphic results and our interpretation of the four Wombat Plateau sites in Figure $9 \mathrm{~A}-\mathrm{D}$ (back pocket). These figures are updated versions of the back-pocket figure 1 of Haq, von Rad, O'Connell, et al. (1990), supplemented by our interpretations regarding paleoenvironmental evolution, tectonic events, sequence stratigraphy, and sea-level fluctuations.

In this section we will mainly discuss the sequence-stratigraphic interpretations of the Triassic strata drilled on the Wombat Plateau. The sequence-stratigraphic terminology used in this paper is discussed in Haq (1991), and touched upon in Haq et al. (this volume).

Four Late Triassic (late Carnian through Rhaetian) sequences have been documented in the composite section (Figs. 7 and 8). Together, Sites 759, 760, 761, and 764 provide a cross-sectional view of the depositional settings ranging from fluviodeltaic plain-swamp-interdistributary bay to prodelta, in a mixed clastic-carbonate system, as well as from shallow-water-lagoonal-patch and coral reef to an open-marine shelfal environment in a carbonate system.

\section{Site 759}

Site 759 (location $16^{\circ} 57.2^{\prime} \mathrm{S} ; 115^{\circ} 33.6^{\prime} \mathrm{E}$; water depth 2091.9 m) was drilled on the southeastern flank of the Wombat Plateau, which is separated from the Exmouth Plateau proper by a half graben (Fig. 6). 


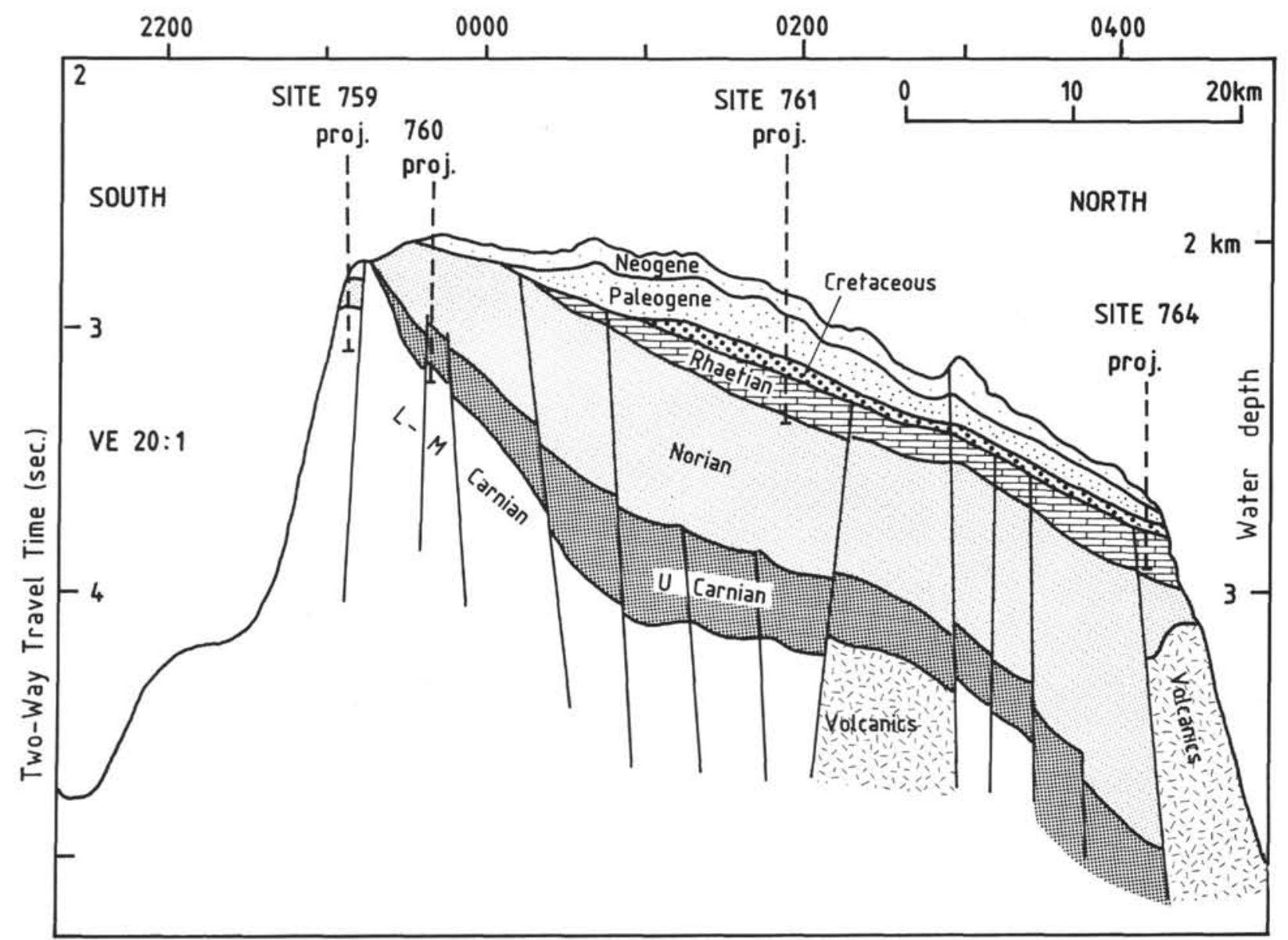

Figure 6. Interpreted multichannel seismic section across the Wombat Plateau (Rig Seismic profile 56-13) with the location of Sites 759-761 and 764. The Wombat Plateau is a tectonic horst that was uplifted during a major Jurassic rift phase, tilted, and subaerially eroded. Note that gradually younger horizons are preserved northward from Site 759 to Site 761 below the major post-rift unconformity. Note also the thin cover of Lower Cretaceous to Cenozoic post-breakup sediments (Williamson et al., 1989).

Approximately $268 \mathrm{~m}$ of late Carnian-Norian deltaic, marginal-marine to open-shelf claystone, sandstone, and carbonates were recovered at this site, which are unconformably overlain by Early Cretaceous hemipelagic quartz sand and late Tertiary to Holocene oozes (Fig. 9A, back pocket).

The lower $103 \mathrm{~m}$ of this section (Cores 122-759B-23R to $-39 R$, lithologic Unit V) is a silty claystone with thin siderite layers deposited in prodelta to open-shelf environment. The palynomorph biofacies (see Brenner, this volume, chapter 23) also indicate marginal-marine to open-marine conditions in this part of the section, which represents the transgressive systems tract (TST). This sequence is characterized by an overall upward deepening to the maximum flooding surface, although individual parasequences show coarsening-upward claystone-siltstone-limestone sections (Fig. 9A, back pocket). The carbonate in Core 122-759B-23R marks the level of optimum transgression or the maximum flooding surface (MFS) within the sequence. The MFS is overlain by a $36-\mathrm{m}-$ thick, predominantly regressive facies (lime-mud) and shallow subtidal to supratidal sediments with in-situ coal seams. This package marks the highstand systems tract (HST), the upper half with coal measures represents the most regressive late highstand phase when the accommodation is significantly reduced and the shoreline regresses rapidly basinward.

A sequence boundary (SB) occurs within Core 122-759B-20R and is marked by a change from regressive facies of the late highstand phase (below) to transgressive facies laid down in mar- ginal to open-marine setting (above). The $\mathrm{SB}$, which correlates with the 224-Ma SB of Haq et al. (1988), is also overlain by "transgressive" acritarchs (Brenner, this volume, chapter 23) that may be reworked at this surface. The TST (Cores 122-759-20R to -16R) consists of upward-shallowing parasequences of silty claystone, sandstone, and carbonate with reworked coal fragments within an overall deepening-upward trend.

A bed with conglomerate/shell breccia in Core 122-759B$16 \mathrm{R}$ (probably a tempestite; Röhl et al., this volume), denoted by a gamma-ray peak in well logs and overlain by a short, upward-deepening and -fining parasequence, might represent an MFS. The surface also marks the Carnian/Norian boundary and coincides with the Late Triassic rift event that led to widespread block-faulting on the plateau. The overlying short, upward-deepening event is interpreted as representing a condensed section, enhanced by accelerated deepening of this block associated with block-faulting following rifting.

The HST overlying the MFS (Cores 122-759B-7R to -16R) consists largely of regressive marginal-marine facies becoming progressively shallower upward, ending in delta-plain facies with coal seams in the upper part. This represents the late highstand phase of reduced accommodation and rapidly regressing shoreline.

The HST is topped by a SB which might be a new SB (about $220 \mathrm{Ma}$ ) not included in the cycle chart (Haq et al., 1987) (see Fig. 9A, back pocket, and Fig. 7), represented by a hiatus in Core 122-759B-7R. This SB is overlain by transgres- 
sive sands and shallow-marine deposits of the TST. A ravinement surface (individual transgressive surfaces of erosion within the TST; see Haq, 1991) may be present above the transgressive sands near the top of Core 122-759B-7R.

The TST (Core 122-759B-6R) is abruptly terminated by a major, 90-m.y. (late Norian through Neocomian) hiatus representing the post-rift unconformity (PRU). The PRU is overlain by deeper water, Neocomian hemipelagic lag deposits (Core 122-759B-5R) representing the juvenile-ocean phase. In Core 122-759B-4R and above, the section passes into the Neogene (the mature-ocean phase) overlying another major unconformity at the top of Core 122-759B-5R.

\section{Site 760}

Site 760 (location $16^{\circ} 55.3^{\prime} \mathrm{S}$, longitude $115^{\circ} 32.5^{\prime} \mathrm{E}$, water depth $1969.7 \mathrm{~m}$ ) is located $5 \mathrm{~km}$ north (upslope and downdip) of Site 759 on top of the Wombat Plateau (Fig. 6).

Approximately $420 \mathrm{~m}$ of late Carnian to late Norian marginal-marine, lagoonal to deltaic sediments topped by the PRU were recovered at Site 760 . The middle late Norian sediments are directly overlain by Neocomian hemipelagic strata (see Fig. 9B, back pocket), much like those at Site 759.

The lower $66 \mathrm{~m}$ of the Upper Triassic section (Cores $122-760 \mathrm{~B}-22 \mathrm{R}$ to $-29 \mathrm{R}$ ) comprise the HST of the unrecovered sequence below. These consist of prodelta silty claystone and sandstone with coccolithophores, becoming marginal marine upward. The upper part also contains good in-situ coal seams and shallow-water red algae near the top, representing the late highstand phase of reduced accommodation and basinward progradation (cf. Haq, 1991). An alternative interpretation places an MFS marked by calcareous algae grainstone in Core $122-760 \mathrm{~B}-25 \mathrm{R}$. This would make the claystone in Core 122$760 \mathrm{~B}-25 \mathrm{R}$ through $-29 \mathrm{R}$ a part of the TST. However, this cannot be ascertained without the lower (undrilled) section. We prefer the former interpretation because there is little or no change in the cyclic pattern below and above Core 122760B-25R, which shoals upward in the section.

The SB (224 Ma) lies above the late highstand facies in Core $122-760 \mathrm{~B}-22 \mathrm{R}$, a boundary marked by abrupt change from shallow- to deeper water facies (transgression) and an increase in carbonate content. The TST (Cores 122-760B-19R to $-22 \mathrm{R}$ ) is characterized by marginal-marine facies with reworked coal fragments, and intercalated codiacean and dascycladacean limestones (Röhl et al., this volume).

Near the top of Core 122-760B-19R an erosional surface is marked by a conglomeratic bed, which might coincide with the Carnian-Norian boundary and might represent an MFS. As at Site 759 , this surface is also overlain by a short, upward-deepening parasequence (Röhl et al., this volume). The surface correlates with the rift event that led to widespread block-faulting. The upwarddeepening parasequence contains evidence of slumping and debris flow, which is consistent with the tectonic nature of this surface and explained by accelerated deepening of the block, following rift-type block-faulting.

The HST above the tectonically enhanced condensed section consists of about $90 \mathrm{~m}$ (Cores $122-760 \mathrm{~B}-9 \mathrm{R}$ to $-18 \mathrm{R}$ ) of restricted marine to delta-plain facies with increasing terrigenous input and evidence of storm deposits in the upper half. This upper part represents the regressive and prograding facies of the late highstand phase. The carbonate-rich part of the systems tract (Cores $122-760 \mathrm{~B}-14 \mathrm{R}$ to $-17 \mathrm{R}$ ) represents a shallow-water "keep-up" and "catch-up" carbonate system which "gives up" in the late highstand time when terrigenous influx increases (Kendall and Schlager, 1981). A ravinement surface (minor erosional surface) may be present in Core 122-760B-14R. The SB (220 Ma) occurs in the middle of Core 122-760B-8R, where facies deepens from delta (below) to shallow marine and lagoonal (above the boundary). There is also a marked increase in carbonate content within the overlying TST.

The MFS above the TST is not very obvious in this section, but is placed between Cores $122-760 \mathrm{~A}-30 \mathrm{X}$ and $-31 \mathrm{X}$ following an overall change from a proximal marine delta facies (below) to more restricted marginal-marine facies (above) that become progressively shallower upward. The carbonate content of the sediments also decreases dramatically at this level and remains generally low in the overlying HST (Cores 122-760A$11 \mathrm{X}$ to $-30 \mathrm{X}$ ), when the system is overwhelmed by terrigenous influx derived from Gondwana to the southeast. The marginalmarine parasequences of the HST prograde basinward and become more regressive upward during the late highstand phase. The PRU is encountered between Cores $122-760 \mathrm{~A}-10 \mathrm{X}$ and $-11 \mathrm{X}$, truncating the Triassic syn-rift sequence.

\section{Site 761}

Site 761 (location $16^{\circ} 44.23^{\prime} \mathrm{S}, 115^{\circ} 32.10^{\prime} \mathrm{E} ; 2167.9 \mathrm{~m}$ water depth) is located approximately $20 \mathrm{~km}$ north of Site 760 on the central part of Wombat Plateau (Fig. 6). The site was selected because seismic facies suggested a section younger than that at Site 760. Stratigraphic highlights include:

1. A complete marine Rhaetian carbonate platform section with foraminifers, ostracodes, nannofossils, and palynomorphs, which may be unique at present for the Southern Hemisphere;

2. A condensed hemipelagic Tithonian-Berriasian section with belemnites;

3. A restricted Neocomian calcisphere nannofossil chalk section with six discrete thick bentonite (altered ash) beds;

4. A biostratigraphically complete Cretaceous/Tertiary boundary; and

5. A nearly complete Paleocene section, which is very valuable for magnetostratigraphy, stable isotopes, and plankton stratigraphy, including radiolarians.

In the lower part of Site 761 approximately $172 \mathrm{~m}$ of uppermost Norian to Rhaetian shallow-subtidal to lagoonal and openmarine carbonates were recovered (Fig. 9C, back pocket, and Fig. 8). The base (between Cores 122-761C-32R and -33R) contains an SB $(215 \mathrm{Ma})$ which is close to the Norian-Rhaetian boundary (between Cores $122-761 \mathrm{C}-31 \mathrm{R}$ and $-32 \mathrm{R}$ ). The SB is marked by a change from fluviodeltaic coal swamps below (representing the late highstand phase of the previous cycle) to shallow- to open-marine transgressive facies above.

The TST consists of a nearly 100-m-thick section (Cores 122-761C-21R to -32R) of deepening-upward parasequences of clay stone and "keep-up"//catch-up" carbonates, with clastic input decreasing upwards. An MFS is reached with the first indication of pure carbonate sedimentation in Core 122-761C-20R.

About $57 \mathrm{~m}$ of largely neritic limestone with foraminifers and megalodonts above the MFS comprise the HST. Across the MFS the environment of deposition changes from subtidal marl/limestone alternation of the TST, to subtidal/protected lagoonal carbonates with foraminifers of the HST.

An SB that might correlate with the 211-Ma SB of Haq et al. (1987) may be present in the interval of Core 122-761C11R. Although the core itself was not recovered, the gammaray log extending down to this level shows upward-shoaling followed by a suddenly deepening parasequence (von Rad and Thurow, this volume). The geochemical log leads to a similar conclusion through change in the carbonate/clastic ratio. The PRU occurs above this level (above Core 122-761C-11R). An alternative interpretation, based on log correlation (Dumont, this volume), puts the "211-Ma" SB at Site 764 considerably deeper (below Core 122-764B-12R), whereas our interpretations agree for Site 761 . 


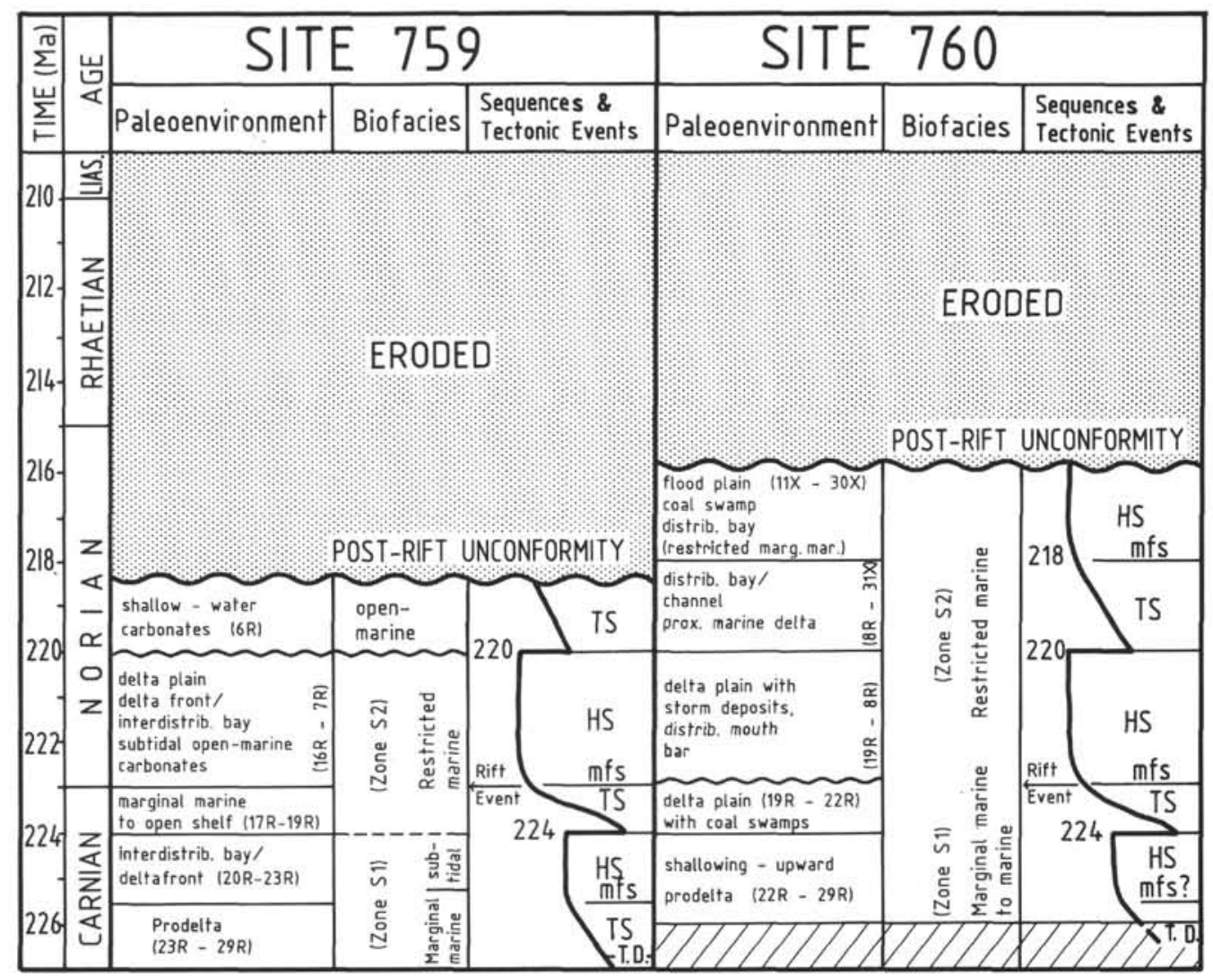

Figure 7. Paleoenvironment, biofacies, tectonics, and sequence stratigraphy of the later Triassic (CarnianNorian) sections recovered from cores at Sites 759 and 760 . Age (Ma) is according to the global cycle chart by Haq et al. (1988). HS = highstand systems tract, TS = transgressive systems tract, MFS $=$ maximum flooding surface, and TD = total depth of hole.

The PRU at this site is first overlain by an unusual ferruginous sand with belemnites (in Core 122-761C-10R) deposited in an outer-shelf, hemipelagic setting in the Berriasian, and then by a pelagic calcisphere nannofossil chalk, both representing transgressive facies (von Rad and Thurow, this volume; Bralower, this volume).

\section{Site 764}

Site 764 is located near the northeastern edge of the Wombat Plateau, approximately $20 \mathrm{~km}$ north-northeast of Site 761 at $16^{\circ} 33.96^{\prime} \mathrm{S}, 115^{\circ} 27.43^{\prime} \mathrm{E}$, in a water depth of $2698.6 \mathrm{~m}$ (Fig. 6). This site together with Site 761 provides a complete transect across Rhaetian carbonate bank (lagoonal/reefal) environments, blanketed by a Cenozoic pelagic succession. The site was drilled on the northeastern flank of the plateau where, because of repetitive erosion and winnowing, the Cretaceous to Cenozoic drape is very thin.

Some $245 \mathrm{~m}$ of Rhaetian reefal carbonates were recovered below the PRU (Fig. 9D, back pocket, and Fig. 8). The bottom of the hole is at 294.5 mbsf (Core 122-764B-31R) in carbonate mudstone/wackestone representing the highstand facies of the previous cycle. A hiatus is suspected within Core 122-764B-31R. The boundary is placed at the change from mudstone (below) to reefal complex (above). Brenner (chapter 23), Bralower et al., and Dépêche and Crasquin-Soleau (all this volume) date Section 122-764B31R-CC as being of Rhaetian age due to the presence of the dinoflagellate Rhaetogonyaulax, and Rhaetian nannofossils and ostracodes. Therefore, the " $215-\mathrm{Ma}$ " sequence boundary at the Norian/Rhaetian boundary was not yet reached at total depth of Site 764 . The suspected hiatus at Core 122-764B-31R may have been responsible for eroding at least part of the underlying siliciclastic sequence.

The TST (Cores 122-764B-15R to -31R) is well developed, providing an excellent example of "keep-up" and "give-up" carbonates of the reefal complex. The keep-up reefal facies with packstone, floatstone, and boundstone are particularly well developed. The exact location of the MFS is difficult to identify in the section of Cores $122-764 \mathrm{~B}-13 \mathrm{R}$ to $-19 \mathrm{R}$, but combining microfacies and geochemical log parameters it can be placed in the middle of the "keep-up" reefal complex (within Core 122-764B-15R; see Fig. 9D, back pocket). This entire segment represents the distal shelf equivalent of a condensed section. The HST (above Core 122-764B-13R, up to Core $122-764 \mathrm{~B}-8 \mathrm{R}$ ) is also comprised of "keep-up" and "catch-up" systems, but the terrigenous input increases as the next SB is approached in Core 122-764B-9R. This SB ("211 Ma") near the top of the Rhaetian (between lithologic Units V and VI) is rather subtle. It can be identified by the change from reefal facies (below) to alternations of marls and limestone (above). The mud-supported limestone contains mollusk debris, foraminifers, and sponge spicules, and the alternating marl/limestone facies represent the TST. The sequence from Core $122-764 \mathrm{~B}-4 \mathrm{R}$ to $-8 \mathrm{R}$ represents two deepening-upward cycles (terrigenous influx increasing upward, shown by the geochemical log; see Fig. 9D, back pocket), which are separated by a distinct break between Cores 122-764B-6R and -5R, interpreted as a short uplift pulse (erosional unconformity?). For a different sequence-stratigraphic interpretation see Dumont (this volume). The PRU tops the uppermost Rhaetian section above Core 122-764B-4R 


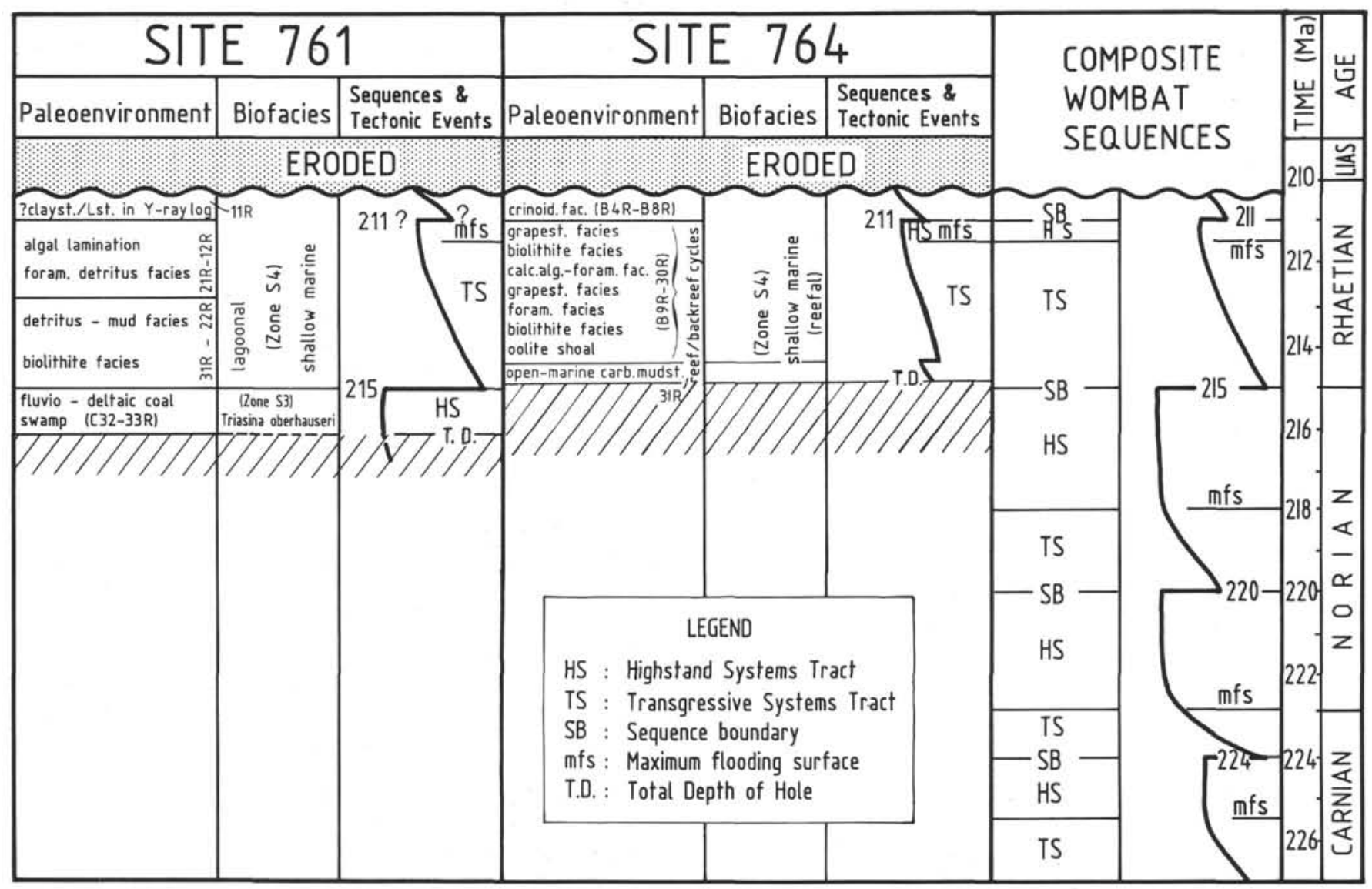

Figure 8. Paleoenvironment, biofacies, tectonics, and sequence stratigraphy of the Late Triassic (Norian to Rhaetian) sections of Sites 761 and 764. A composite sequence stratigraphy of all four Wombat Plateau sites is also shown. HS $=$ highstand systems tract, TS $=$ transgressive systems tract, $\mathrm{SB}=$ sequence boundary, MFS = maximum flooding surface, and TD = total depth of hole.

and is overlain by Upper Cretaceous chalk deposited in a pelagic environment.

\section{EARLY-RIFT PALEOENVIRONMENT (TRIASSIC)}

\section{Permian to Middle Triassic Evolution}

The Exmouth Plateau is part of the Carnarvon Basin (Hocking et al., 1987) and is underlain by continental crust with a Phanerozoic (mainly late Paleozoic to Triassic) sedimentary section which is about $10 \mathrm{~km}$ thick (Exon and Willcox, 1980) and overlies early Paleozoic metamorphic and Precambrian plutonic rocks. Deep crustal seismic data (Mutter et al., 1989; Williamson et al., 1989) show that the Moho can be seen as a major detachment fault about $10 \mathrm{~km}$ deep under the plateau. Permo-Carboniferous rifting attenuated the basement and reduced the lower crustal thickness to about $10 \mathrm{~km}$ from an original thickness of about $25 \mathrm{~km}$ (Pilbara Massive). Later (early Mesozoic) rifting utilized elements of simple and pure shear to produce lesser final extension by block-faulting, prior to breakup and seafloor spreading.

By the Triassic, eastern Gondwana had drifted significantly northward and a temperate and humid climate prevailed (Bradshaw et al., 1988). During the Scythian, a thick, shallow-marine claystone series (Locker Shale) was deposited in a rift within the Carnarvon Basin (Barber, 1988; Hocking et al., 1987). This sequence was overlain by a regressive Anisian to Norian (-Rhae- tian) sequence of 2- to 3-km-thick fluviodeltaic sediments with interbedded coal measures (Mungaroo Formation).

Meandering braided streams fed major delta systems which prograded from the Pilbara Massive toward the northwest. High fluvial sediment supply kept pace with rapid subsidence in the intracratonic basin.

\section{Upper Triassic (Carnian-Norian) Fluviodeltaic and Marginal- Marine Environment}

The paleogeographic situation of the Exmouth Plateau at the Carnian/Norian boundary is shown in figure 7A of Exon et al. (this volume, chapter 1): a broad delta plain grades into a proximal marine delta and farther seaward into a distal prodelta with some shelf carbonates (at Sites 759 and 760). The region of the present Wombat Plateau represents the distal part of this delta system, probably an embayment of Neo-Tethys into eastern Gondwana. Along the western margin of the present Exmouth Plateau, there was a major elongate island characterized by rift volcanics (Exon and Buffler, this volume) that shed its debris into the nearby Wombat area.

A composite section of the four Wombat Plateau sites (see Exon et al., this volume, chapter 1, their fig. 4) shows that a 600-m-thick Carnian to Norian, mainly siliciclastic sequence was penetrated in Sites 759 and 760 . Both drill sites can be correlated, using palynomorph biostratigraphy (Brenner, this volume, chapter 23 ), wireline logs, microfacies, and litho- 


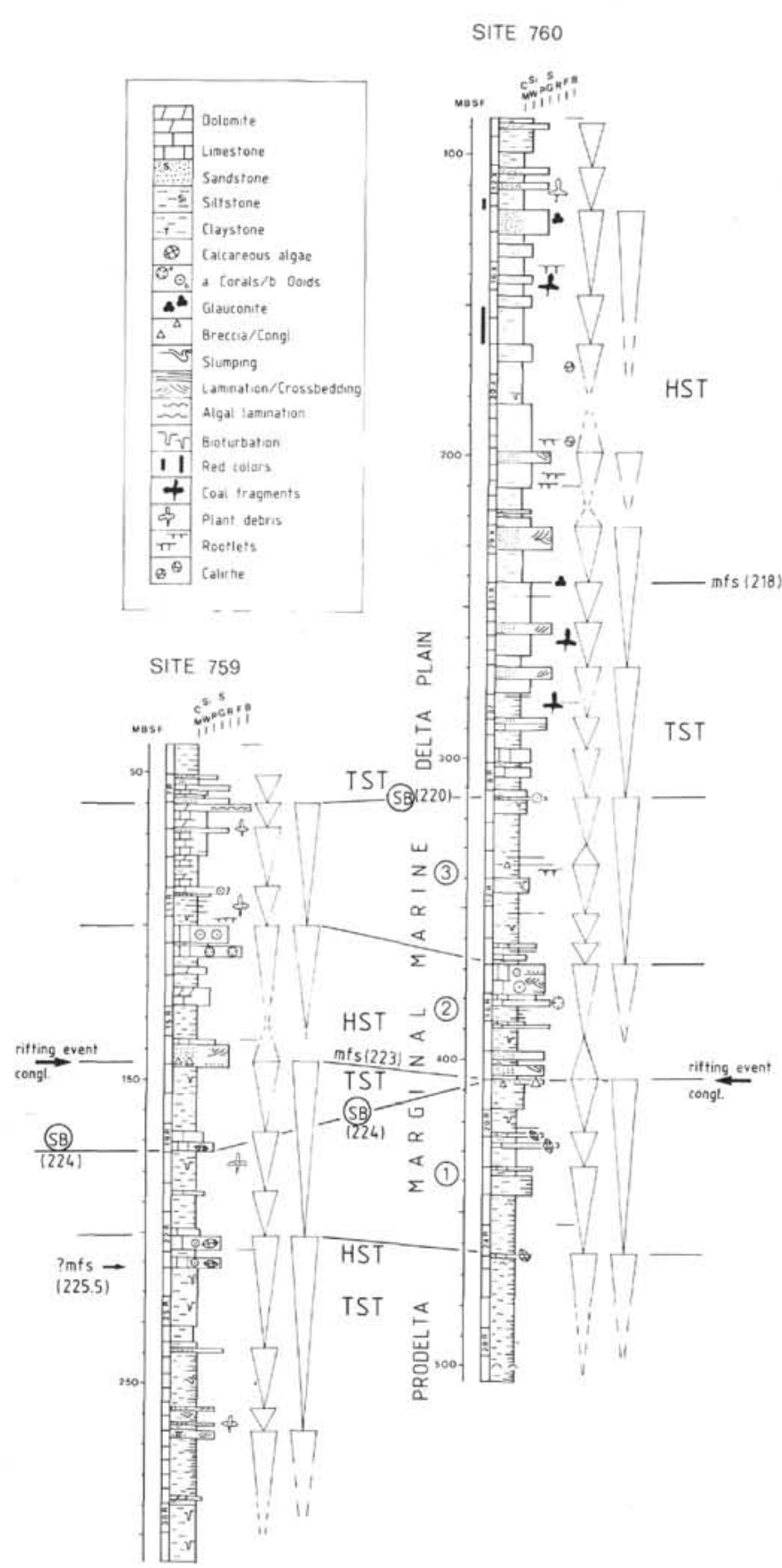

Figure 10. Correlation of the Upper Triassic (Carnian to Norian) sections of Sites 759 and 760 (modified after Röhl et al., this volume, their fig. 6). Note sequence-stratigraphic interpretation and coarsening-upward cycles of different order. The correlatable heteromict conglomerates at $145 \mathrm{mbsf}$ in Site 759 and at $408 \mathrm{mbsf}$ in Site 760 are interpreted as representing a tectonically (rifting event) enhanced maximum flooding surface (MFS). $\mathrm{SB}=$ sequence boundary, HST = highstand systems tract, and TS = transgressive systems tract. (Note: Fig. 7 has a slightly different sequence-stratigraphic interpretation). stratigraphy (Röhl et al., this volume; see Fig. 10). The sequence is a good example for a mixed siliciclastic-carbonate system deposited in a marginal-marine syn-rift environment (Ito et al., this volume). We will first discuss the dominant fluviodeltaic siliciclastic sediments and then the shallow-water carbonate intercalations.

The Carnian-Norian section of Sites 759 and 760 (Figs. 9A, -B, back pocket; Fig. 7) can be subdivided by two sequence boundaries separating three upward-shoaling third-order cycles (from base to top):

1. Middle to upper Carnian prodelta mudstone to delta plain deposits (older than $224 \mathrm{Ma}$ ),

2. Uppermost Carnian to lower Norian marginal-marine to fluviodeltaic sequence topped by a prominent unconformity (224-220 Ma), and

3. Middle to upper Norian proximal marine deltaic to nonmarine delta plain deposits (younger than $220 \mathrm{Ma}$ ).

These cycles of sedimentation consist of a large number of smaller (10-m-scale) shoaling- (or coarsening-) upward sequences (Fig. 10). Such shallowing- (or coarsening-) upward cycles document the common facies shift within a deltadominated, marginal-marine environment (Einsele, 1982).

\section{Middle to Upper Carnian Prodelta to Delta Plain Deposits}

The recovered sequence is about $140 \mathrm{~m}$ thick (Site 759: ca. 170-308 mbsf, Fig. 9A, back pocket; Site 760: ca. 438-508 mbsf, Fig. 9B, back pocket) and consists of a shallowingupward (regressive) clastic sequence with an open-marine distal prodelta mudstone at the base, overlain by intertidal to shallow subtidal delta plain deposits above a "maximum flooding surface"' (225 Ma).

The oldest sediments ever drilled by DSDP/ODP were recovered at Site 759: a 103-m-thick sequence of upper Carnian very dark gray silty claystone alternating with clayey siltstone and sand which is mostly parallel to ripple-cross laminated. At the base of Site 760 a similar sequence was penetrated. Soft-sediment deformation and slump structures suggest rapid deposition. The lack of a normal-marine mollusk fauna, the black color and high organic carbon content $(0.5 \%$ $2.5 \%$ ), the abundance of pyrite and siderite, and the excellent preservation of laminations (i.e., lack of bioturbation) indicate that the sediments were deposited under oxygen-depleted, low-energy conditions. Organic matter is dominated by type III kerogen which is thermally immature $(<0.5 \%$ vitrinite reflectivity) and derived from debris of continent-derived higher land plants (Snowdon and Meyers, this volume). This is common for deltaic and paralic sediments such as the Triassic Mungaroo Formation. If subjected to higher thermal stress than at this location, the sediments contain enough organic matter to generate and expel commercially viable amounts of gaseous hydrocarbons.

Thin siderite layers, lenses, nodules, and burrow fillings were observed at many levels in these mudstones. Significantly, siderite decreases upward whereas pyrite shows the opposite trend, indicating increasingly more restricted (brackish) conditions from the base of Site 759 toward Core 122759B-25R.

The prodelta mudstones also contain a continuous assemblage of minute ancestral siderite-replaced coccolith-like nannofossils (Bralower et al., this volume). These observations suggest an open-marine distal prodelta (or basinal) environment in a water depth between a few tens to about $100 \mathrm{~m}$, that is, well below wave depth (cf. also Einsele and von Rad, 1979).

The prodelta mudstone section shoals upward and grades into shallow-subtidal, intertidal, and supratidal siliciclastics 
with in-situ coal seams and shallow-water carbonates, apparently an intradeltaic lagoon to delta front setting.

\section{Uppermost Carnian to Lower Norian Marginal-Marine to} Fluviodeltaic Sequence

This sequence is approximately $130 \mathrm{~m}$ thick (Site 759: ca. 50-170 mbsf, Fig. 9A, back pocket; Site 760: ca. 307-438 mbsf, Fig. 9B, back pocket) and bounded by two sequence boundaries (SB; 224 and $220 \mathrm{Ma}$ according to the cycle chart of Haq et al., 1987). The sequence stratigraphy is supported by detailed palynofacies investigations by Brenner (this volume, chapter 23): acritarchs suggest fully marine, transgressive conditions above the 224-m.y. SB, whereas megaspores and an uphole decrease of marine palynomorphs below the same SB indicate regressive, restricted-marine to nonmarine conditions. The sequence consists of a lower "transgressive systems tract" of open-marine (transgressive) limestones and marginal-marine (paralic) siliciclastics with reworked coal. It is overlain by a conspicuous heterogeneous conglomerate which we assign to a major rift event near the Carnian/Norian boundary. This block-faulting event produced an accentuated relief by local uplift followed by erosion. This is evidenced by a conglomeratic horizon characterized by rounded pebbles of volcanic rocks, reworked wood, mollusks, and terrigenous grains (Röhl et al., this volume). The accentuated subsidence rate after this tectonic event resulted in a local increase in the water depth, corresponding to a relative sea-level rise. This caused a reversal of the normal coarsening-upward cycle, which is replaced by a finingupward cycle (Röhl et al., this volume; Figs. 9A, -B, back pocket). We suggest that the erosional unconformity connected with this tectonic event includes the record of the "maximum flooding surface" ("223 Ma") and produced a tectonically enhanced, condensed section.

The sediments overlying this conglomeratic horizon are marginal-marine siliciclastic sediments with intercalations of bioclastic sands and neritic limestones interpreted as storm deposits. The early Norian transgression shifted the barrier islands northward (i.e., offshore of Site 760) and developed a broad, restricted marine environment in the area of Sites 759 and 760, similar to that of the present American Gulf coast (Ito et al., this volume).

The alternation of shallow-water carbonates with deltaic, siliciclastic facies can be explained by the lateral migration of delta lobes moving over a pre-existing carbonate shelf. The shelf was covered later by another carbonate bank, after the depocenter of the active delta lobe had switched laterally from a "delta abandonment facies" to a new position (Ito et al., this volume).

This Norian sequence consists of an alternation of neritic carbonates with dark-gray, paralic, silty claystone, and a general upward increase of the proportion of carbonates (Fig. 10). Medium quartz sandstone is common only in some intervals. "Ideal" coal-measure cycles consist of regressive, coarsening-upward cycles: bay or prodelta claystone at the base grading into siltstone/sandstone (distributary mouth bar) and finally into organic-rich silty claystone with thin coal seams deposited in swamps in an intra-deltaic setting. Most sequences studied in our cores contain only an organic-rich mudstone with shell and coal debris, overlain by massive and bioturbated mudstone and laminated shale, and capped by sandstone. In-situ coal seams, rootlets, and algal laminites indicate the regressive (inter- to supratidal) end members of the cycles (Fig. 9B, back pocket). The progradational fluviodeltaic sandstone sequences, the carbonate intervals, and the mudstones are more easily identified in the gamma and velocity logs than in the cores themselves (Borella et al., Ito et al., Röhl et al., all this volume).
Middle to Upper Norian Proximal Marine-Deltaic to Nonmarine Delta Plain Deposits (younger than 220 Ma)

This section is mainly represented in Site 760 (95-306 mbsf, Fig. 9B, back pocket) and about $211 \mathrm{~m}$ thick. Sites 759 and 761 have only short sections of this interval. Transgressive facies comprising neritic carbonates and sandstones are overlain by carbonate-free siliciclastic sediments. In general, the clastic sediments show a shallowing-upward (regressive) trend from marine, glauconite-bearing mudstone (inner shelf to lagoon) to marginal-marine, siliciclastic deltaic sediments. The sediments of the lower unit (Site 760, Unit V) were deposited in a shallow- to marginal-marine environment, probably in an estuarine setting with distributary bay channels (Ito et al., this volume).

We noted a few excursions into a subaerial delta plain to coal swamp milieu. Fish debris, glauconite, and mollusks generally indicate a marine setting, whereas lithologic Unit IV of Site 760 is predominantly nonmarine ("late highstand systems tract"). This unit is characterized by black silty claystone, interbedded with clayey siltstone to silty sand. Several horizons with coal seams, root mottling, caliche, and paleosol profiles indicate a subaerial exposure in a marsh, flood plain, delta plain, and coal swamp environment.

\section{Provenance of Carnian-Norian Siliciclastic Sediments}

The main source of the terrigenous components (mono- and polycrystalline quartz, plagioclase, mica, low-grade metamorphic and plutonic rock fragments, and chert), observed in the fluviodeltaic sandstones, was the Precambrian Pilbara Massive and its Paleozoic cover (von Rad and Exon, 1983; Ito et al., this volume).

The sandstones also contain a significant proportion of epiclastic, altered volcanic rock fragments, pumice, and volcanogenic minerals, such as sanidine crystals (von Rad, unpubl. data). Although the rock fragments are highly altered, a full range from basaltic to intermediate to highly differentiated (?rhyolitic, ?trachytic) lithologies appear to be present. The volcanics were eroded from pre-existing volcanic rocks during tectonic or eustatic events. They might, however, also indicate times of intense volcanicity.

Volcanic rock fragments are concentrated at two stratigraphic levels:

1. Near the Carnian/Norian boundary (Cores 122-759B-16R and $-17 \mathrm{R}$, and $122-760 \mathrm{~A}-16 \mathrm{R}$ to $-21 \mathrm{R}$ ): intermediate (?trachytic) to basaltic rock fragments, sanidine, and altered pumice. This volcanism is apparently associated with a major rift phase at about $223 \mathrm{Ma}$ (Figs. $9 \AA$, -B, back pocket).

2. Near the early Norian (" $220 \mathrm{Ma}$ ") sequence boundary (Core 122-759B-7R to-8R; 122-760A-38X; 122-760B-6R and -9R): these volcanic rock fragments signal an important, hitherto unknown period of late Carnian/early Norian (intermediate to alkalic?) early-rift volcanism.

Early-rift volcanic rocks of latest Rhaetian to early Liassic (212-195 Ma) age were reported by von Rad and Exon (1983) and von Rad et al. (1990) from dredge material from the northern escarpment of Wombat Plateau. Volcanism of intermediate to alkaline character is typically associated with continental rifting: it is characterized by eruptions of small volume from shallow magma chambers; the rocks are highly differentiated and associated by volcaniclastic sequences (Fisher and Schmincke, 1984; Hooper, 1990).

\section{Carnian-Norian Shallow-Water Carbonate Environments}

The delta-dominated Carnian/Norian sequences " $\mathrm{A}$ " and "B" (see preceding section) include several shallow-water car- 
bonate intercalations which increase in frequency up-section, due to the general shallowing of the environment (Fig. 10).

The limestone intercalations contain large proportions of terrigenous debris (quartz, etc.) and are partly interpreted as storm deposits (tempestites), derived from a marginal carbonate platform, Partly, they are bioclastic sands, washed together in front of river deltas, and intertidal to lagoonal limestones and deposited in restricted areas within a tidal flat and/or interdistributary bay. From base to top Röhl et al. (this volume) distinguish:

1. A calcareous algae dominated facies with oolites (with dascycladacean and coated grainstone, codiacean floatstone), deposited in channels which dissected the shallow-marine fluviodeltaic platform;

2. An oolitic/oncolitic dominated facies including dolomites and floatstones bearing coral or sponge fragments, deposited - on oolite shoals or intradeltaic lagoons; and

3. An oolitic/algal-stromatolitic dominated facies (with foraminiferal wacke- to floatstones), deposited on tidal flats or on oolite shoals or in interdistributary bays.

\section{Rhaetian Transgression: Lagoonal and Reefal Carbonates}

The Rhaetian shelf limestone recovered in the Wombat Plateau sites, and especially the reefal facies of Site 764 , represent the first discovery of Upper Triassic platform carbonates anywhere in the well known Australian Northwest Shelf region. This has potentially opened up a new target for petroleum exploration in the region (Williamson et al., 1989; Exon et al., 1989). This 160 -m-thick (Site 761) to 230 -m-thick (Site 764) sequence was studied in detail by shipboard and shore-based scientists and we will quote extensively from these papers, especially Dumont, Röhl et al., and Sarti et al. (all this volume).

\section{Paleogeography}

The paleogeography during Rhaetian time is characterized by a major southward transgression. In the Wombat Plateau area, the delta plain paleoenvironment (Site 760) changed into a shallow-marine shelfal carbonate setting (see Exon et al., this volume, chapter 1, their fig. 7B). Due to a northward drift of Gondwana, northwest Australia and northern Greater India lay at $25^{\circ}-30^{\circ} \mathrm{S}$ (Klootwijk and Bingham, 1980; Ogg et al., in press) and faced the open equatorial Tethys sea. Thus, it is not surprising that coral, sponge, and hydrozoan reefs flourished near the outer edge of a broad carbonate platform with lagoons, patch reefs, and tidal flats, which in turn lay seaward of a delta system similar to that of the Norian stage. This evolution is analogous to that of the western Tethyan environments in the Alps, which were at similar latitudes in the Northern Hemisphere.

\section{Seismic Stratigraphy and Structural Evolution}

The Rhaetian sediments can be subdivided using highresolution seismic profiles into reefal and lagoonal facies (Williamson et al., 1989; Exon et al., 1989). Criteria for the recognition of reefs include a zone of low reflectivity over the reef core, blanking of seismic energy beneath the core, and downlapping seismic facies around the reef core, corresponding to wedges of reef-derived detritus. In general, the reefs appear to be patch reefs, and they may be concentrated on structurally high blocks.

A detailed study of the five suitable seismic lines near Sites 761 and 764 by Williamson (this volume) shows that three seismic sequences can be identified within the Rhaetian strata. The entire sequence is unconformably overlain by Cretaceous sediments, the unconformity being clearly angular in the south and almost subparallel in the north. Sarti et al. (this volume and pers. comm., 1990) have suggested that there is no erosional unconformity on top of the Rhaetian, but only a nondepositional submarine exposure surface spanning the Jurassic. However, seismic data (Williamson, this volume) show clearly the progressively younger nature of the terminations of dipping Rhaetian strata below the main (post-rift) unconformity to the north, proving its angular and erosive character.

In general, the Rhaetian (except for its latest part) was a tectonically quiescent period of moderate platform subsidence compensated by carbonate buildup. It is characterized by two sequence boundaries, one at the Norian/Rhaetian boundary and one near the top of the Rhaetian. These sequence boundaries are overlain by transgressive systems tracts followed by highstand systems tracts (Figs. 9C, -D, back pocket; Fig. 8). The two shallowing-upward sequences correspond to thirdorder depositional cycles of the global cycle chart (Haq et al., 1987; see also "Wombat Plateau Sequence Stratigraphy" section, this chapter).

\section{Development of the Carbonate Platform and Depositional Environment}

Detailed microfacies analysis of over 500 thin sections by various investigators allowed clear characterization of the depositional environment. The large stratigraphic (Carnian to Rhaetian) and lateral facies range (lagoon-shoal-reef to openmarine shelf) of the recovered shallow-water carbonates allows the definition of many microfacies types. Based on the kind and amount of the major biogenic and abiogenic allochems, Röhl et al. (this volume, their table 1) distinguished 25 main microfacies types. Bralower et al. (this volume) studied the ancestral Triassic coccoliths (Fig. 11).

The Rhaetian series of the Wombat Plateau can be correlated between Sites 761 and 764 (Brenner, chapter 23; Dumont; Röhl et al., all this volume). The correlation by Röhl et al. (this volume) is based on microfacies analysis, gamma spectroscopy logs, and the interpretation of paracycles (Fig. 12).

The rapid early Rhaetian transgression starts after a major sequence boundary ("215 Ma"), overlying carbonate mudstone and black carbonaceous claystone with coal. The sequence boundary coincides with the transgressive surface (Figs. 9C, -D, back pocket).

Site 761 is characterized by an intertidal flat to lagoon environment with many deepening-upward (transgressive) limestone/marl parasequences (transgressive systems tract). They grade upward into a sand shoal facies with patch reefs in a lagoonal setting (highstand systems tract; Fig. 9C, back pocket). Site 764 (Fig. 9D, back pocket) shows a similar development, but with typical features of reef development with higher carbonate productivity and several reefal/lagoonal cycles (Fig. 13).

The upper Norian to lower Rhaetian section of Sites 761 and 764 contains the coccolith Prinsiosphaera triassica and several other taxa (Fig. 11). The low diversity of the assemblage and the low proportion of coccoliths suggest a somewhat restricted environment. Open-ocean conditions are, however, indicated by stable isotopes (Bralower et al., this volume). These ancestral nannofossils are an important discovery of Leg 122 and help to refine the biostratigraphy and taxonomy for the Late Triassic.

Using a sequence-stratigraphic approach, we can subdivide the Rhaetian section into four systems tracts (A-D). There is no lowstand systems tract between the SB and the TST, since the tops of carbonate platforms typically lack lowstand wedges, which can only be found off-bank (Haq, 1991). 


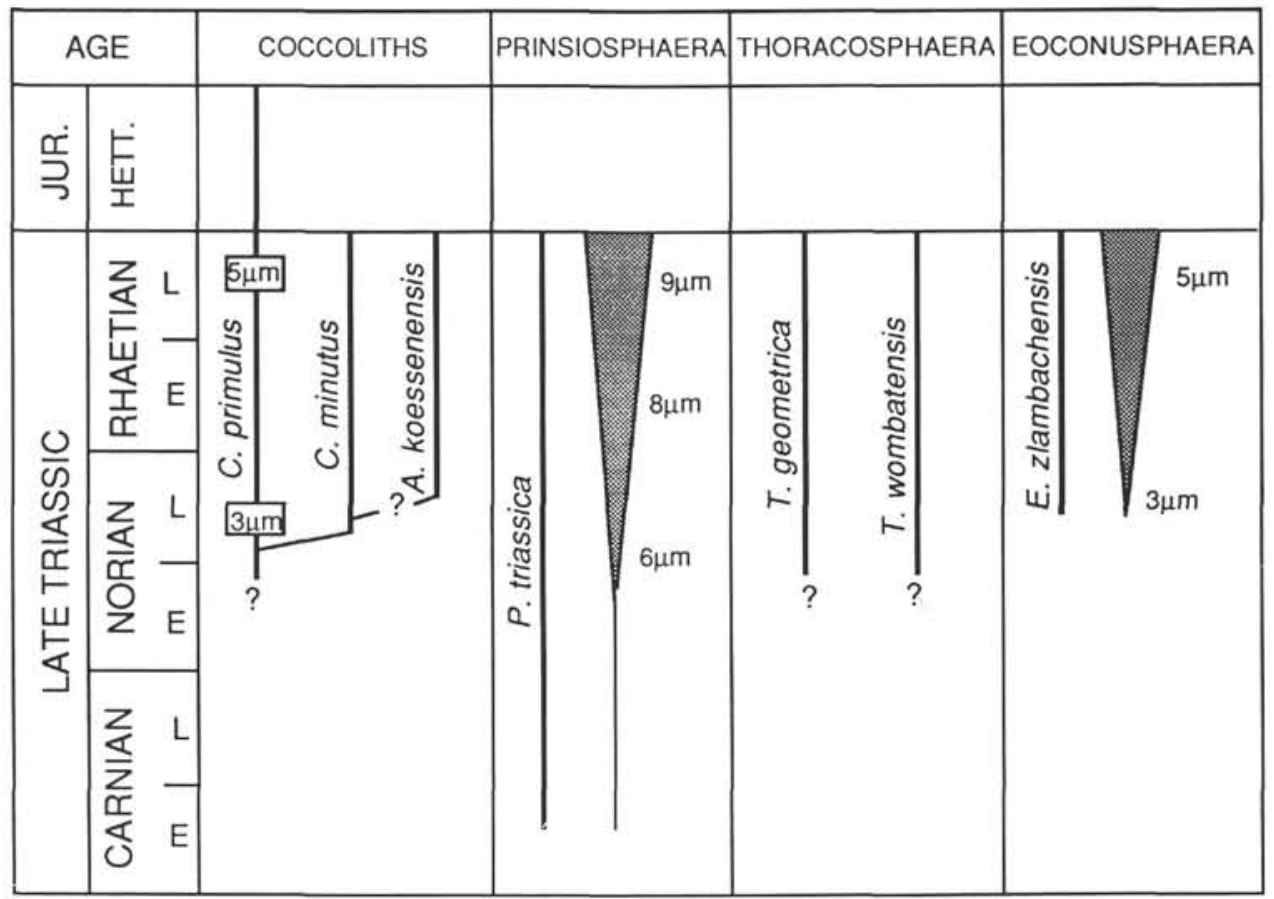

Figure 11. Stratigraphic summary of evolution of ancestral calcareous nannoplankton in the Upper Triassic (Bralower et al., this volume, their fig. 7). Chronostratigraphic assignments are from a combination of palynology (Brenner, this volume, chapter 23) and foraminiferal (Zaninetti et al., this volume) and nannofossil biostratigraphy.

Systems tract A: The lower Rhaetian transgressive systems tract between the lower sequence boundary ("215 Ma") and the maximum flooding surface ("211.5 Ma"). At Site 761 this represents the beginning of carbonate buildup with deepeningupward limestone/marl cycles (Fig. 9C, back pocket). In Site 764 this sequence is characterized by reef growth (Fig. 9D, back pocket). Reef development is controlled by an interplay between water energy, sea-level fluctuation, and growth potential of the reef organisms: bioclastic sands ("basal pile") are overlain by an oolite shoal ("stabilization stage"), calcisponge/hydrozoan reefs ("colonization stage"), and finally by a coral reef ("diversification stage"; Röhl et al., this volume). The mobile ground was first colonized by a sponge-dominated community and then by a coral-dominated association; Retiphyllia dominated the main core of a pinnacle reef complex, but Astreomorpha associations in the upper section indicate that the growth of the corals kept up with the rising sea level (Sarti et al., this volume). Röhl et al. (this volume) distinguished several lagoonal to reefal cycles which indicate a "keep-up" to "catch-up" carbonate system (Fig. 12). The slim shape of the reefs recognized by Williamson (this volume) in the reflection profiles across Wombat Plateau may also indicate the fast growth of the reef organisms that were able to keep up with the rising relative sea level ("keep-up system"; Kendall and Schlager, 1981).

Systems tract B: The "middle Rhaetian highstand systems tract" between the maximum flooding surface ("211.5 Ma") and the upper sequence boundary ("211 Ma"). In Site 761, this sequence consists of many shallowing-upward (regressive) cycles consisting of pure wackestones with Megalodon and/or Triasina at the base of each cycle and less pure, supratidal algal laminite at the top (Fig. 9C, back pocket). In Site 764 this member is characterized by patch to pinnacle to back reefs in a "keep-up system" (Fig. 9D, back pocket).
Systems tract C: The "upper Rhaetian transgressive systems tract," overlying the upper sequence boundary ("211 Ma") in Site 764, is a deepening-upward sequence of openmarine shelf marl and claystone (a "give-up svstem"; Fig. 9D, back pocket). In Site 761 this sequence is indicated only by a limestone/claystone cycle, interpreted from the gamma-ray wireline logs (no core recovery).

Systems tract D: In Site 764, an "uppermost Rhaetian" deepening-upward sequence of open-marine crinoidal grainand packstone was recovered, overlying an unconformity (Fig. 9D, back pocket).

In general, the sequence-stratigraphic interpretations of Dumont (this volume), Röhl et al. (this volume), and this chapter are in agreement, although the upper sequence boundary ("211 Ma") is placed differently. Site 761 represents a "more proximal," lagoonal setting with comparatively high terrigenous input, Site 764 a more "distal" shelf margin environment with reefs or shoals. Since seismic reflection profiles (Williamson, this volume) revealed many patch reefs on Wombat Plateau with an apparent random distribution, the terms "proximal" or "distal" indicate only relative distance to a shoreline located to the southeast and no representative setting.

The facies development is schematically illustrated by Figure 12 (see Röhl et al., this volume).

In member 1 (Fig. 12) the base is comprised of "lower" Rhaetian open-marine shelf marl/limestone alternations (Site 761). These alternations were caused by changes in the terrigenous supply and energy conditions.

Within the lagoonal area, with restricted conditions created by the reef development, Site 761 has calcisponge patch reefs and corallinacean buildups. In the area of Site 764 the first reef development followed an oolitic shoal phase.

During the "middle" Rhaetian (member 2, Fig. 12) the reefal facies persisted near Site 764 ; it was dominated by 
SITE 764

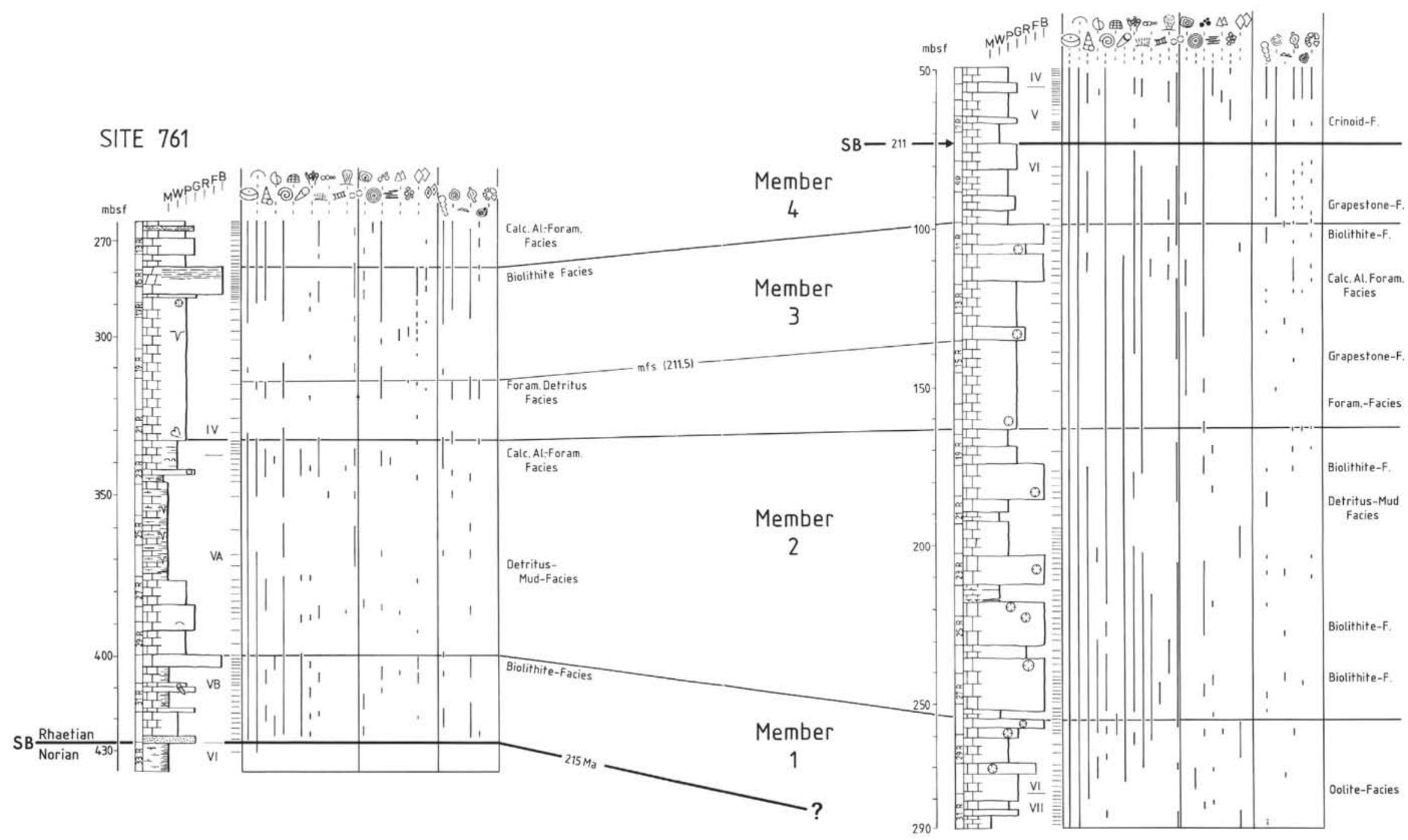

Figure 12. Comparison of the Upper Triassic (Norian to Rhaetian) sections of Sites 761 and 764 (modified after Röhl et al., this volume, their fig. 8). Correlation is made by wireline logs (gamma-ray spectroscopy), lithofacies and biofacies, and sequence stratigraphy. $\mathrm{M}=$ mudstone, $\mathrm{W}=$ wackestone, $\mathrm{P}=$ packstone, $\mathrm{G}=$ grainstone, $\mathrm{R}=$ rudstone, $\mathrm{F}=$ framestone, and $\mathrm{B}$ $=$ bafflestone. For explanation of microfacies symbols see Röhl et al. (this volume). 


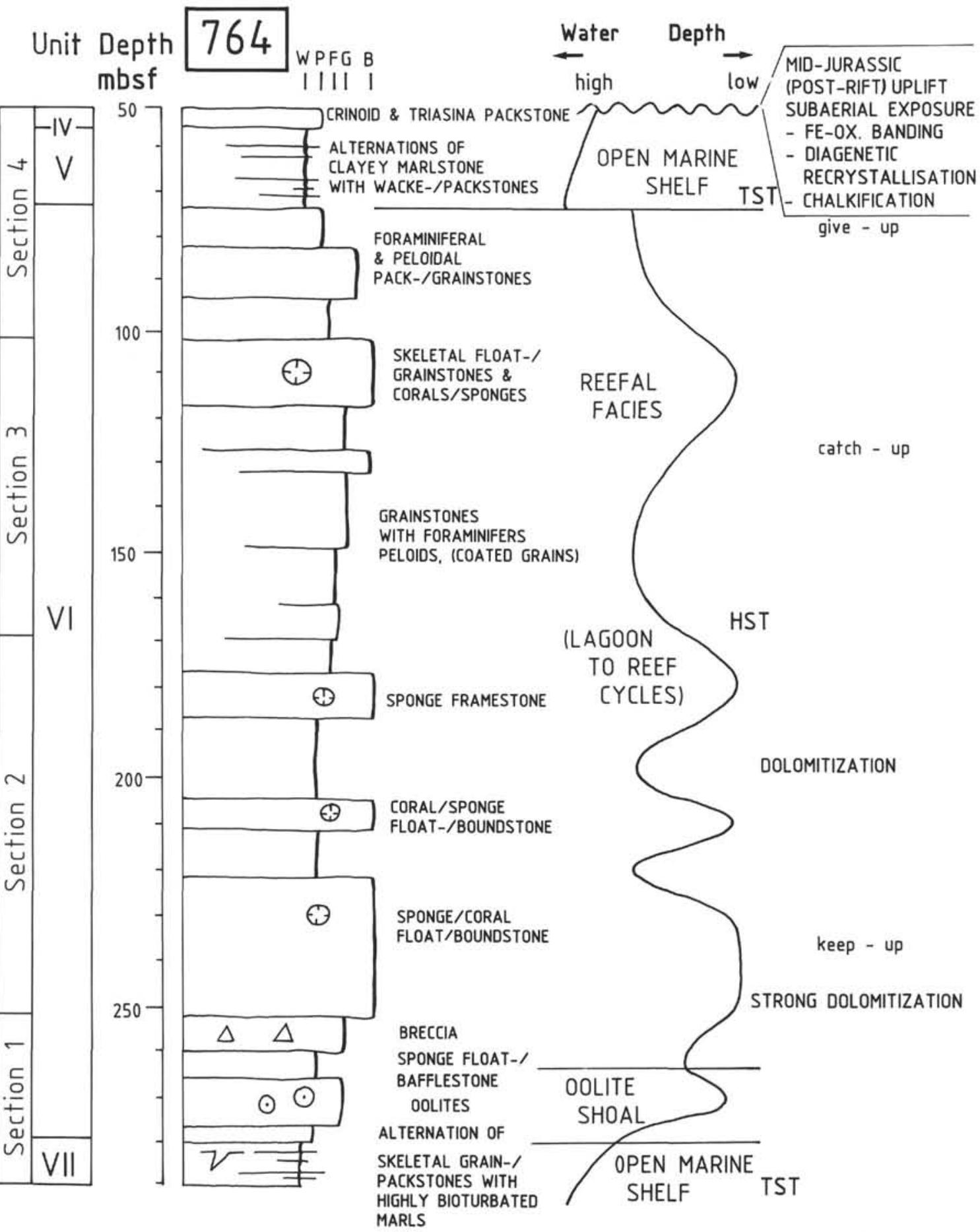

Figure 13. Cyclicity in the Rhaetian sediments of Site 764 (modified after Röhl et al., this volume, their fig. 9). Note the "keep-up," "catch-up," and "give-up" carbonate systems (cf. Kendall and Schlager, 1981) and the sequence-stratigraphic interpretation with two sequence boundaries, transgressive (TST), and highstand (HST) systems tracts, and the post-rift unconformity capping the top of the Rhaetian. $\mathrm{W}=$ wackestone, $\mathrm{P}=$ packstone, $\mathrm{F}=$ framestone, $\mathrm{G}=$ grainstone, and $\mathrm{B}$ $=$ bafflestone. 
marl/limestone alternations, controlled by changing terrigenous input and periodic high-energy (e.g., storm) events. Biogenic allochems and bioturbation indicate a more restricted environment if compared to the marl/limestone cycles of the "lower" Rhaetian of Site 761.

The "upper"' Rhaetian (member 3, Fig. 12) was characterized by the dominance of grapestone or foraminiferal-algal facies at Site 764. During the same interval, Site 761 developed regressive cycles from lagoonal foraminifer- and Megalodon-bearing wackestones to algal bindstones.

The "uppermost" Rhaetian transgressive pulse caused renewed sedimentation of marl/limestone alternations at Site 764, which include crinoids, brachiopod shells, and some sponge spicules. Relatively deeper-water crinoidal sands of ?Early Jurassic age were found only in dredge samples.

In summary, we suggest that continuing tectonic subsidence during the Rhaetian resulted in a slow relative sea-level rise. The reefal facies show first "catch-up" deposits that grade upward into "keep-up" cyclic deposits. Drowning of the carbonate platform during a major relative latest Rhaetian sea-level rise, which was probably caused by accentuated tectonic subsidence and eustatic sea level rise, killed the reefs (= "give-up") and terminated carbonate buildup.

From a sequence-stratigraphic viewpoint, the Rhaetian formation of the Wombat Plateau can be characterized as an evolution from a "transgressive systems tract" ("lower" Rhaetian) via a "highstand systems tract" (lagoonal and reefal facies of the "upper" Rhaetian) back to a "transgressive systems tract"' ("uppermost"' Rhaetian). A lowstand systems tract is missing on the top of carbonate platforms.

Figure 14 shows the interpretation of Röhl et al. (this volume) of the Rhaetian depositional settings at various sites, plotted in a three-dimensional facies model of the Wombat Plateau. The fluviodeltaic setting, the siliciclastic-dominated marine environments, and the carbonate platform are shown as separate blocks within this diagram. Sites 759 and 760 represent the fluviodeltaicdominated series of the Carnian and Norian and Sites 761 and 764 the Rhaetian carbonate platform. The time-equivalent Rhaetian series in the area of Sites $759 / 760$, which were eroded by the Jurassic post-rift unconformity, are assumed to be fluviodeltaic or mixed fluviodeltaic/shallow-water carbonate. Site 761 reflects an intertidal to shallow-subtidal lagoonal setting, while Site 764 is characterized by better ventilated subtidal oolite shoals, reef, and reefal debris.

\section{Comparison with Western Tethyan Triassic Facies (Alps)}

As mentioned above, two global Late Triassic (Rhaetian) sea-level events (sequence boundaries) are documented in Sites 761 and 764 by lithofacies and biofacies, and by log character (Figs. 12 and 15). Detailed comparisons of the geodynamic settings between Europe and the Australian margin by Dumont (this volume) indicate that there is a difference between the European and Australian Rhaetian series. The latter shows a sequence boundary inside the upper part of the Rhaetian, but in the former the sequence boundary coincides with the Triassic/Jurassic boundary ("Adneter Wende" = turnover of Adnet).

Apart from this tectono-eustatic sea-level change, which was probably caused by major plate-tectonic reorganizations, the Rhaetian facies of the Wombat Plateau shows a conspicuous similarity to that of the western Tethys. As in the Wombat Plateau area, the base of the Rhaetian in the western, southern, and northern Alps is characterized by significant upward-decreasing terrigenous input which may be explained by global sea-level changes (Dumont, this volume). In the Northern Calcareous Alps (for references see Röhl et al., this volume), the Kössen marls (limestone and marly shale facies) can be compared to the marl/limestone alternations within Site 761. Also the northern alpine "upper Rhaetian limestone" (Oberrhätkalk) can be compared to the reefal series in Site 764, and the Zlambach beds to the overlying foraminiferal and crinoidal limestones (Figs. 9C, -D, back pocket). The lithofacies of the alpine early Liassic limestones and marls (Adnet limestone, Hierlatz limestone) is similar to that of the fine-clastic upper Rhaetian (-Liassic?) series, which overlie the reefal facies in the uppermost cores of Site 764 and are represented in dredge material from the northern Wombat Plateau escarpment (Fig. 15).

The microfacies and facies evolution in our drill sites show that the reefal facies of Site 764 is similar to the "Oberrhätriffkalk" (upper Rhaetian reefal limestone; Stanton and Flügel, 1989) and/or "Dachsteinriffkalk" (Dachstein reef limestone; Zankl, 1971) of the Northern Calcareous Alps. Site 761 reflects the lagoonal facies of the "gebankter Dachsteinkalk" (bedded Dachstein limestone; Piller, 1976) with regressive cycles. The geodynamic evolution of the east Gondwanan Tethyan margin around the Triassic/Jurassic boundary is also very similar to the synchronous evolution of the European margin of the Ligurian Tethys exposed in the Western Alps of France (Dumont, this volume).

\section{JURASSIC RIFT-DRIFT TRANSITION}

The Jurassic period was characterized by major rifttectonic and volcanic events that preceded the continental breakup during the latest Jurassic to earliest Cretaceous. These events dramatically changed the paleoenvironment of the Exmouth Plateau margin. Although there is no Jurassic stratigraphic record on the eastern Wombat Plateau (nondeposition or erosion by the post-rift unconformity), this chapter will outline the evidence about Jurassic sequences nearby, from seismic reflection profiles, commercial wells, and dredge material, to summarize the Jurassic rift-drift history.

\section{Early Jurassic Paleogeography}

During the Early Jurassic (Liassic), the Exmouth Plateau was still within the subtropical latitudes $25^{\circ}-30^{\circ} \mathrm{S}$; Ogg et al., in press). The Early Jurassic (Hettangian/Sinemurian) paleogeography is shown by Exon et al. (this volume, chapter 12, their fig. 7C). The major change since the Rhaetian was a further deepening of the depositional environment, possibly with block-faulting. On the Exmouth Plateau thin marls were deposited on a shelf that was separated from the open Tethys by a volcanic landmass, indicated by seismic profiles (Exon and Buffler, this volume) and by dredged volcanics at the northern Wombat Plateau margin. "Deeper-water"' (i.e., outer shelf to upper slope) limestones, dredged from northern Wombat escarpment and the Cygnet Canyon/Swan Canyon area (Fig. 1), include crinoidal packstone and a mud- to wackestone without calcareous fossils, but with redeposited large wood fragments and occasional quartz grains (von Rad and Exon, 1983; von Rad et al., 1990; Röhl et al., this volume). The age of these hemipelagic to turbiditic(?) limestones is poorly constrained: Kristan-Tollmann and Gramann (this volume) suggest a Rhaetian age but do not exclude a Rhaetian to Early Jurassic age for some samples. The microfacies suggests a differentiation of the carbonate platform into several swells and deeper basins during the Rhaeto-Liassic. A similar situation prevailed in the western Tethys, where the upper Rhaetian reef limestones are overlain by Liassic crinoidal limestones (Hierlatzkalk), red ammonite-bearing marlstone (Adneter Kalk) or open-marine marls (Flecken-Mergel, Zlambach-Mergel; see Fig. 15). 


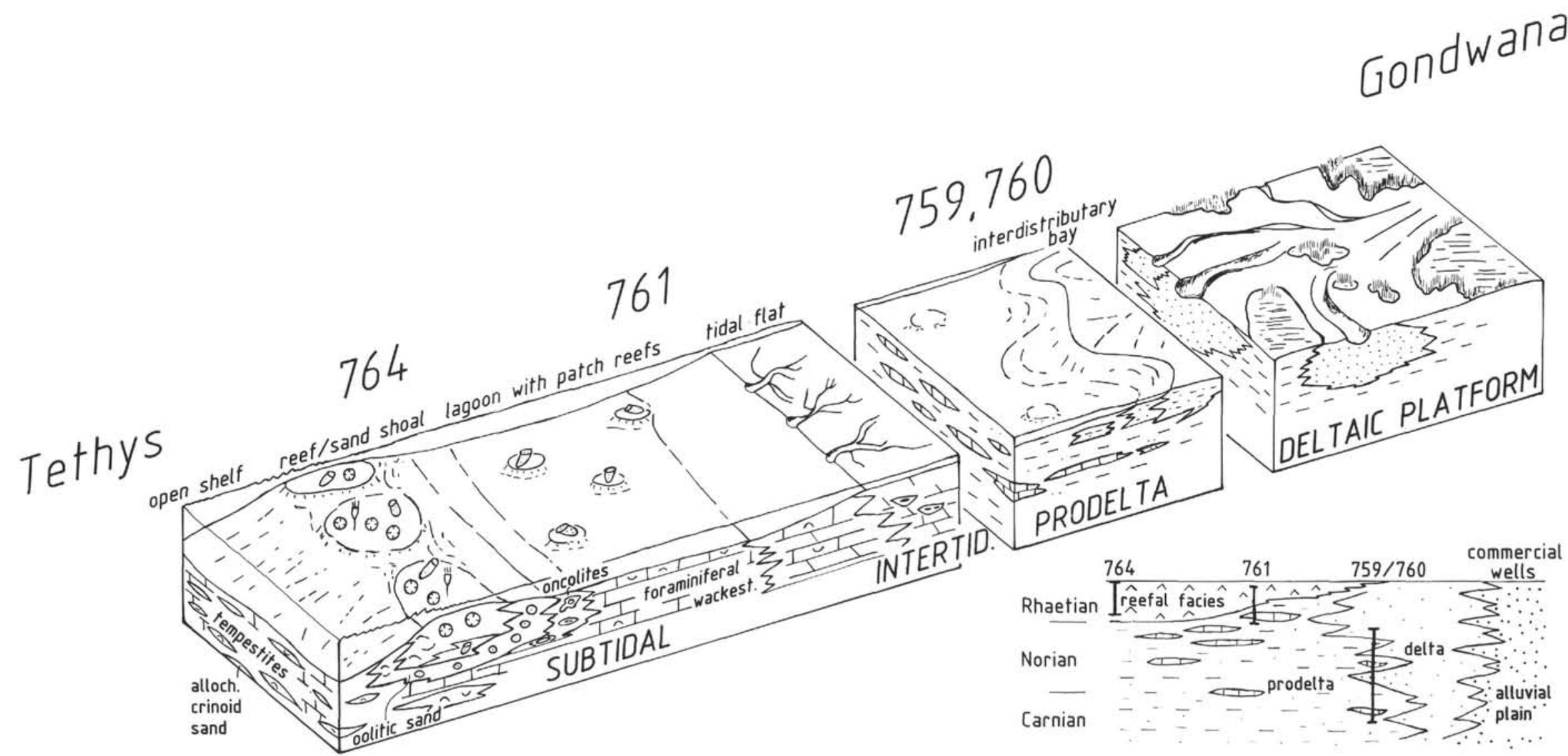

Figure 14. Generalized facies model for the Wombat Plateau, Sites 759-761 and 764 (from Röhl et al., this volume, their fig. 12). 


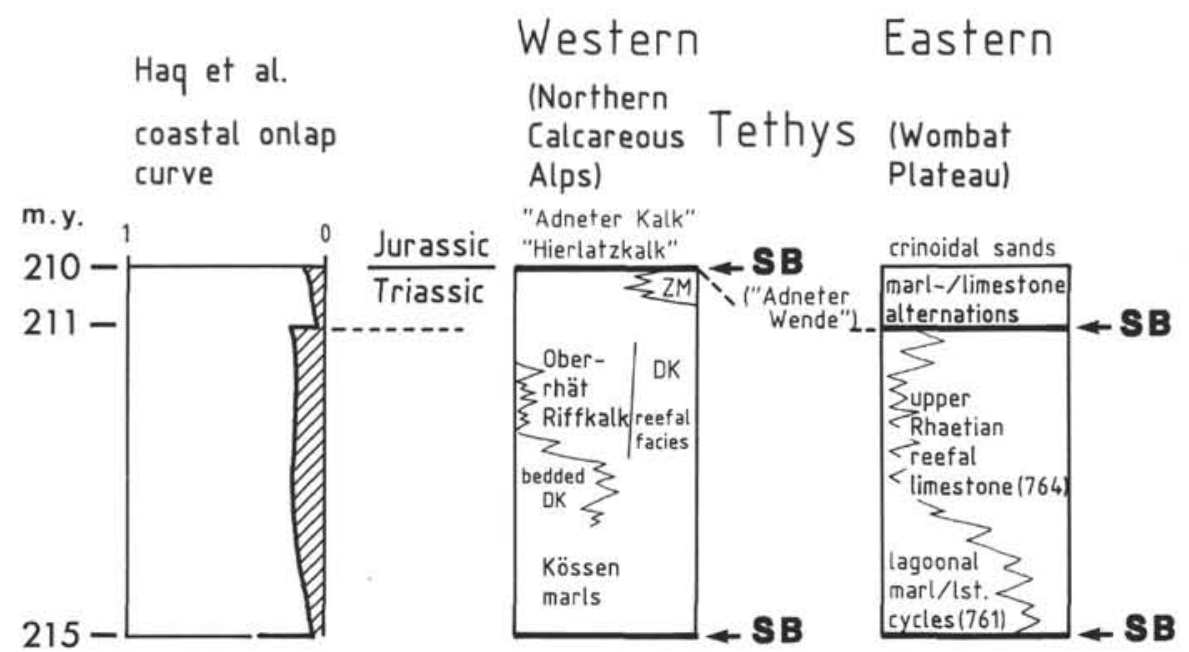

Figure 15. Comparison of western and eastern Tethyan facies and sequence stratigraphy (modified from Röhl et al., this volume, their fig. 11) with Haq et al. (1988) time scale. Note good correlation of general facies and global eustatic events. $\mathrm{SB}=$ sequence boundary, $\mathrm{DK}=$ Dachsteinkalk, and $\mathrm{ZM}=$ Zlambach beds.

\section{Rhaeto-Liassic Rift Tectonics and Syn-Rift Volcanism}

The Wombat Plateau is a marginal plateau that was affected by several rifting pulses throughout the Mesozoic: one is documented near the Carnian/Norian boundary (see "Provenance of Carnian-Norian Siliciclastic Sediments" section, this chapter); one is suggested by major Early Jurassic volcanic or tectonic events occurring in the vicinity of the Wombat Plateau (Dumont, this volume; Fig. 16). This crustal extension caused (1) volcanic eruptions of small volume (from shallow magma chambers) and diverse (intermediate to alkaline) composition (cf. White and McKenzie, 1989; Hooper, 1990); and (2) a drastic change in the subsidence pattern of the margin, including the initiation of rapidly filled nearshore rift basins (Barrow-Dampier) and marginal plateaus, such as Exmouth and Scott plateaus (latest Pliensbachian "rift-onset unconformity", Hocking et al., 1987). Similar synchronous events are recorded on the European passive margin of the Ligurian Tethys in the Western Alps (Fig. 16; Dumont, this volume). This suggests a global plate-tectonic cause for the reorganization of subsidence patterns and individualization of nearshore basins and marginal plateaus (e.g., the Alpine Briançonnais Platform and the Wombat Plateau) at the Triassic/Jurassic boundary (Dumont, this volume).

During a late Rhaetian (K-Ar age: $213 \mathrm{Ma}$ ) to early Liassic (K-Ar age: 190-206 Ma) intracratonic rift phase, a suite of highly differentiated $\mathrm{K}$-rich rhyolitic to trachytic rocks erupted along the northern Wombat Plateau, probably under subaerial to very shallow-marine conditions (von Rad and Exon, 1983; von Rad et al., 1990). Volcanic activity in a "rift-valley situation" between the "Argo landmass" or "Mount Victoria Land block" (now located in Burma) is indicated by intermediate volcanics in Burma (Görür and Sengör, this volume), by the early Liassic volcanics dredged from the contingent Wombat Plateau, by early Liassic basaltic flows alternating with Hettangian neritic limestone at the Scott Plateau well Scott Reef No. 1, and by the strong magnetic anomaly found landward of the continent-ocean boundary south of the Argo Abyssal Plain (Veevers, 1988). However, we do not condone Görür and Sengör's (this volume) interpretation that this was an island arc/back-arc volcanic setting along a convergent margin.
Short-lived volcanic activity accompanied the major platetectonic reorganization at or near the Rhaetian/Hettangian boundary in the Western Alps, eastern and western Pyrenees, Ebro Basin, Baleares, Betic zone, Sicily, Morocco, U.S. East Coast, and northwest Australia (Dumont, this volume). The synchroneity of these magmatic and tectonic events with global eustasy is conspicuous.

Görür and Sengör (this volume, chapter 5) suggest that these volcanics indicate "oceanic spreading" at the end of the "Tethyan" Carnian-Rhaetian rifting, coinciding with pronounced thermal subsidence (foundering of the Wombat Plateau) and an opening of an arm of the Mesozoic eastern Tethys. During this assumed Early Jurassic breakup a north Gondwanan continental block might have been ripped off northwest Australia (Veevers, 1988; Görür and Sengör, this volume). However, the arguments for the formation of "true ocean" off northwest Australia during the Early Jurassic are speculative and the volcanics were probably produced during subaerial or shallow-submarine late-rift eruptions, and not during continental breakup.

In our opinion, the Wombat Plateau has to be viewed in the context of the wealth of regional structural and paleoenvironmental information available for the northern Exmouth Plateau and the Northwest Shelf. All these data point to an ongoing late-rift evolution of the northern Exmouth Plateau until the Middle Jurassic, when uplift and rifting produced the widespread "post-rift unconformity" (Fig. 16; Dumont, this volume). Not before the Late Jurassic was true oceanic crust formed in the adjacent Argo Abyssal Plain.

\section{Middle Jurassic Coal-Measure Sequence}

The paleogeography during the Middle Jurassic (Bathonian to Callovian, that is, prior to the formation of the post-rift unconformity) is shown in figure 7D of Exon et al. (this volume, chapter 1). The Exmouth Plateau and the adjacent Tethyan Himalaya (Nepal) was at relatively higher $\left(30^{\circ}-40^{\circ} \mathrm{S}\right)$ latitudes at that time compared to the Late Triassic/Liassic; this resulted in increased siliciclastic input and reduced carbonate deposition (Gradstein et al., 1989b). The major change is the intense structuring of Exmouth Plateau by northeastsouthwest-trending faults. Rankin Platform became an emergent horst, whereas very thick (up to $2000 \mathrm{~m}$ ) paralic to 
Wombat plateau events :

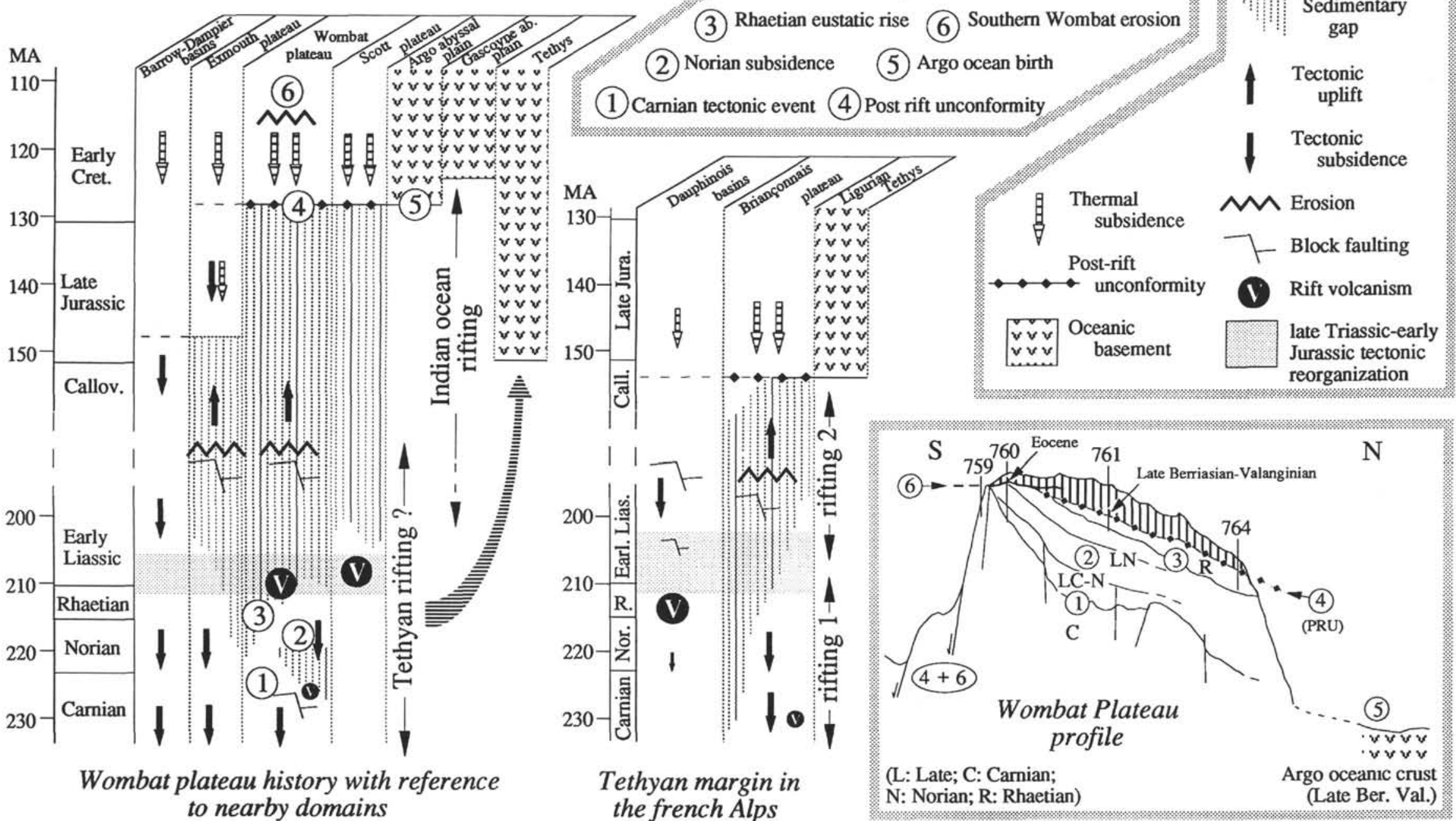

Figure 16. Chronology of stratigraphic, tectonic, and volcanic events on the Wombat Plateau and adjacent areas, compared with the evolution of part of the northern Tethyan margin in the French Alps (from Dumont, this volume, his fig. 6). The Triassic/Jurassic boundary appears in both cases as the key period of major tectonic reorganization: shift of subsidence patterns, birth of marginal plateaus, and rift volcanism. 
shallow-marine siliciclastic sediments were deposited in troughs and basins located on both sides of this platform. Most of the central and western Exmouth Plateau was an emergent erosional area. Studies on dredge material by von Stackelberg et al. (1980), von Rad and Exon (1983), Exon et al. (1988), and von Rad et al. (1990) show that there is a thick paralic Middle Jurassic coal-measure sequence, consisting largely of mudstone, siltstone, and sandstone, in the Swan Canyon area of the northern Exmouth Plateau (Figs. 1, 4A). A silty claystone dredged from Swan Canyon was dated as Toarcian to Bathonian by dinoflagellates (W. Brenner, pers. comm., 1990). A similar Bathonian to Bajocian sequence in Delambre No. 1 well is $1007 \mathrm{~m}$ thick (Fig. 5). Middle Jurassic sequences are, however, thin to absent on the central Exmouth Plateau and on the Wombat Plateau, which appear to have been high areas at that time. Some shelf carbonates are interbedded with the coal measures in the Swan Canyon area; for example, a quartz-rich crinoid grainstone.

This sequence documents the Middle Jurassic regression with deltaic sedimentation (floodplain claystones, channel sands, delta foresets, and coal swamps) alternating with marginal-marine sedimentation (von Rad et al., 1990). Impregnation of many of these sediments with goethite cement was probably a late-diagenetic process during lateritic weathering in a desert environment after the Callovian/Oxfordian uplift.

\section{Middle/Late Jurassic Extensional Tectonics (Block-Faulting)}

The paleogeography after the Callovian/Oxfordian post-rift unconformity is shown in figure $8 \mathrm{~A}$ of Exon et al. (this volume, chapter 1). The late-rift tectonics caused major uplift of large parts of the Exmouth Plateau. A trough persisted southeast of the Rankin Platform. The Tethys sea invaded the southern Exmouth Plateau area, where the condensed sequence of the Dingo Claystone, a shallow-water marine claystone and marl, was deposited. The northern Exmouth Plateau was ingressed from the north, as documented by dredged paralic claystones and shelf carbonates in the Swan Canyon area and along the Rowley Terrace (N. F. Exon, unpubl. data). A major high along the western edge of the present Exmouth Plateau can be assumed.

A mid-Callovian to early Oxfordian hiatus is not only observed on the Exmouth Plateau, but also in the Tethyan Himalaya (Nepal). In Nepal, this hiatus is marine and appears to be due to a global sea-level rise (Gradstein et al., 1989b). Upper Jurassic sediments were only locally deposited on the Exmouth Plateau as thin, condensed marine claystones ("Upper Dingo Claystone') or hemipelagic marls and micritic limestones (Swan Canyon dredges).

Regional geological evidence from seismic profiles and commercial wells indicates that the Wombat Plateau experienced uplift and northward tilting during an important, brief ( $<5$ m.y?) Callovian/Oxfordian rift phase. Isostatic (flexural) rebound might be the reason for the tilting because the adjacent Wombat half-graben subsided at the same time as the Wombat horst was uplifted along a major normal (listric?) fault with a thrust of several kilometers (Fig. 2A). After uplift above sea level, Wombat Plateau was strongly eroded, forming the major "post-rift unconformity.",

According to an alternative hypothesis (Sarti et al., this volume and pers. comm., 1990), the Wombat Plateau did not experience any tectonic structuring, uplift, and subaerial erosion during the Jurassic, but underwent slow ("thermal") subsidence, extreme condensation to nondeposition on a sediment-starved, drowned carbonate platform, when most sediment was trapped along the margins of the continent.

Several studies included in this volume and published elsewhere have produced evidence for the post-depositional uplift and erosion of Wombat Plateau during the Jurassic. This evidence includes (1) regional geological and seismic data (see "Structural and Depositional Setting" section, this chapter), (2) post-depositional, late-diagenetic overprinting of the Rhaetian carbonates, and (3) the composition of the lower Neocomian transgressive sand at Site 761 (see the following sections, this chapter).

Seismic and regional geological evidence (Dumont, this volume; Exon et al., 1982; Veevers, 1988; Williamson, this volume) shows the existence of a widespread erosional postrift unconformity of Callovian/Oxfordian age that caps Upper Triassic sequences at the Wombat Plateau, while at the same time Lower to Middle Jurassic sediments are preserved over most of the northern Exmouth Plateau (e.g., Swan Canyon area) and in Delambre No. 1 well (see "Structural and Depositional Setting', section, this chapter). This unconformity is commonly overlain by a thin (uppermost Jurassic to Neocomian "juvenile-ocean") sequence.

Diagenetic evidence (Dumont; Röhl et al., this volume) suggests that the syn-Rhaetian diagenetic features were strongly overprinted by a Jurassic late-diagenetic phase that affected the whole Upper Triassic sediment pile during the post-Rhaetian uplift of the Wombat Plateau above sea level. Röhl et al. (this volume) identified an upward increase in moldic porosity and dedolomitization features, because of a presumed upward increase of freshwater influence in the upper Rhaetian sections of Sites 761 and 764. Fe-oxide laminations in Site 764 indicate a reduction/oxidation boundary and were probably due to a fossil groundwater horizon.

Sarti and Kälin (this volume) contend that stable isotopic data from carbonate cements bear a clear marine signal. However, in our opinion this does not preclude post-depositional freshwater diagenetic influence, as the cements are syn-Rhaetian and hence naturally marine. Isotopic measurements of cavity-filling calcite cannot conclusively solve the issue because the trace amounts of meniscus/gravitational/ scalenohedral cement in the uppermost cores of Sites 761 and 764 just below the post-rift unconformity were not analyzed.

\section{BREAKUP OF THE ARGO ABYSSAL PLAIN}

The start of seafloor spreading in Argo Abyssal Plain lead to the formation of the incipient Indian Ocean (Fig. 17). This event was dated by magnetic seafloor anomalies that can be calibrated by the age of the oldest sediments or oceanic basement, recovered in two boreholes, DSDP Site 261 and ODP Site 765.

According to biostratigraphic data of DSDP Site 261 (Veevers, Heirtzler, et al., 1974), reinterpreted by Bown and Dumoulin (in press), the oldest sediments overlying oceanic basement in this site are of late Kimmeridgian to early Tithonian age. This correlates with the M23 magnetic anomaly, identified for this site by Fullerton et al. (1989) and Ogg et al. (in press).

For Site 765, drilled on magnetic anomaly M26, a K/Ar age of the celadonite, cementing a basaltic hyaloclastite directly overlying basaltic basement and underlying the oldest sediments in Core 123-765C-62R (Ludden, Gradstein, et al., 1990) is $155 \pm 3 \mathrm{Ma}$ (Ludden and Dionne, in press). This age corresponds to "upper Callovian"' according to the Haq et al. (1987) scale, or to "late Oxfordian to early Kimmeridgian" according to the Kent and Gradstein (1986) scale. The oldest datable sediments in Core $123-765 \mathrm{C}-62 \mathrm{R}$ are of late Kimmeridgian to Tithonian age on the basis of nannofossils, whereas radiolarian assemblages suggest a late Berriasian to earliest Valanginian age (Kaminski et al., in press). However, there is a $4.5-\mathrm{m}$ interval of barren sediments between the lowermost dated samples and oceanic basement, suggesting a 


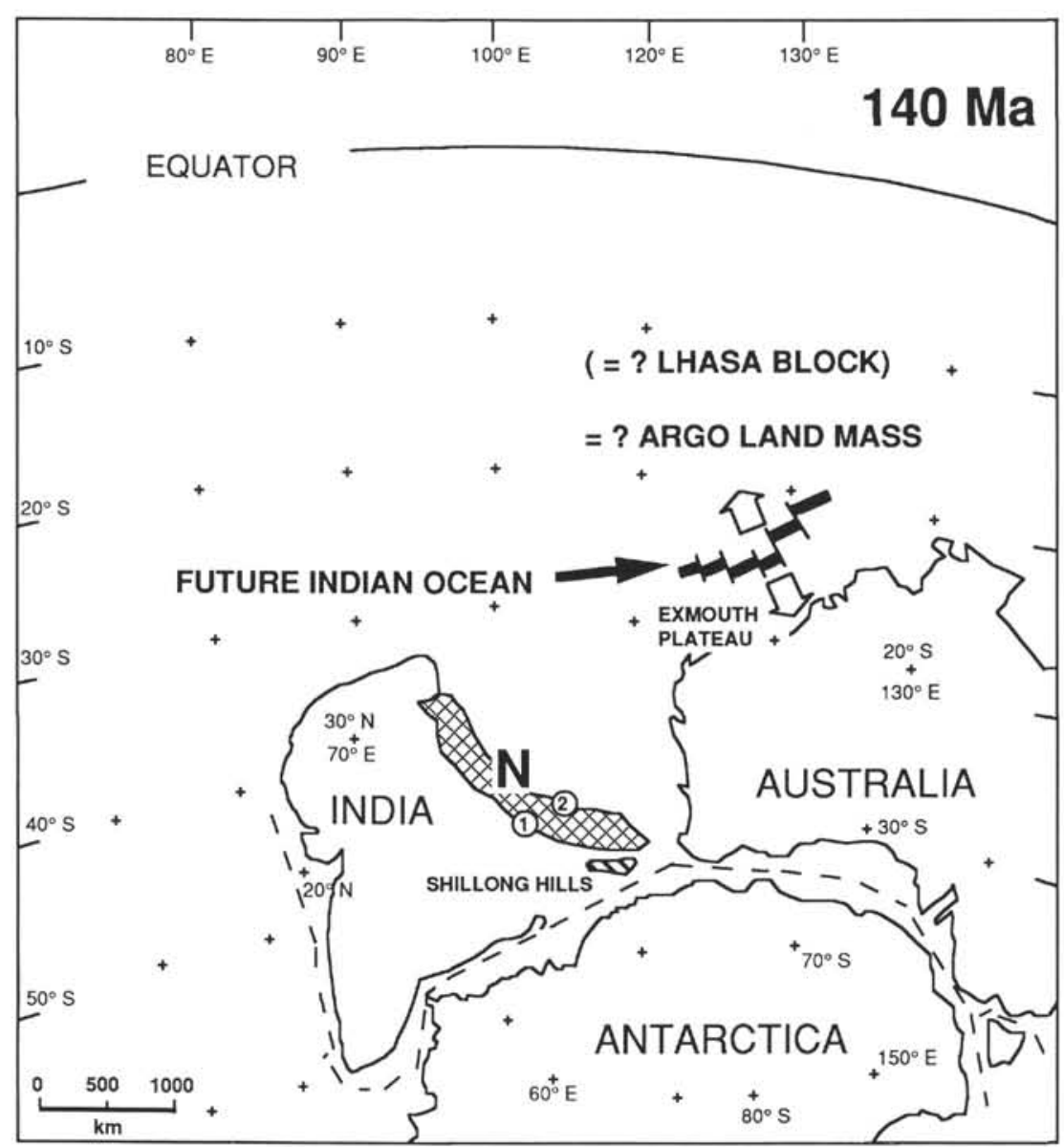

Figure 17. Latest Jurassic/earliest Cretaceous paleogeographic reconstruction of southeastern Tethys showing minimum northern edge of India (compressed stage). 1 = Main boundary fault of Himalaya (present); 2 = Indus-Tsangpo Suture; $\mathrm{N}=\mathrm{Nepal}$ (Thakkhola section); and cross-hatched area indicates Himalayan Tethys sediments (modified after Powell et al., 1988, with new paleomagnetic data for Nepal and northwest Australia from Ogg et al., in press). From Gradstein et al. (1989b).

hiatus or extremely condensed sedimentation between $155 \mathrm{Ma}$ (basement) and the Kimmeridgian/Tithonian.

Hence it appears that the "basement ages" of both Argo Abyssal Plain sites $(261,765)$ agree fairly well with the magnetic anomalies. At about the Oxfordian (M26, $155 \mathrm{Ma}$ ), seafloor spreading started in Argo Abyssal Plain between northwest Australia (Gondwana) and the "Argo Landmass" (South Tibet-Burma; see Fig. 18A). This southward jump of the spreading center from the Neo-Tethys in the north eventually led to the closure of Mesozoic Tethys and to the opening of the Indian Ocean. The rapid Late Jurassic subsidence of the oceanic crust of Argo Abyssal Plain also induced coeval subsidence of the nearby outermost continental margin block, that is, the Wombat Plateau (see fig. 8A of Exon et al., this volume, chapter 1).

\section{JUVENILE-OCEAN PALEOENVIRONMENT (EARLY CRETACEOUS)}

\section{Juvenile-Ocean Stage}

During the Tithonian to Valanginian, coinciding with the beginning of seafloor spreading in Argo Abyssal Plain, both the young ocean basin and the adjacent passive margins experienced rapid subsidence. Tensional stress produced a lowering of the flanks of the margin and hence a landward migration of the shoreline and a typical onlap pattern. The "juvenile-ocean stage" is characterized by (1) hemipelagic transgressive sediments with a strong, upwarddecreasing terrigenous influence (condensed sections); (2) restricted marginal-marine flora and fauna, indicating a "stressed environment"; and (3) post-breakup volcanism, indicated by altered ash layers (bentonites).

\section{Late Jurassic/Neocomian Plate-Tectonic Setting, Paleogeography, and Paleoceanography}

During the latest Jurassic, eastern Gondwana had drifted southward once again, placing northwest Australia in temperate mid-latitudes ( $35^{\circ} \mathrm{S}$ according to Ogg et al., in press). Figure 17 shows the plate-tectonic setting at that time (about $134 \mathrm{Ma}$ ): Eastern Gondwana is still intact with AntarcticaAustralia-Greater India connected. In this reconstruction the northern margin of "Greater India" (India and Tethyan Himalaya) lies close to and southwest of the Exmouth Plateau (Gradstein et al., 1989b).

Seafloor spreading in the Argo Abyssal Plain started in the Oxfordian/Kimmeridgian. The hypothetical "Argo Landmass,"' located north of this proto-Indian Ocean drifted northward and was possibly accreted to the Laurasian continent as "Sikuleh-Natal fragment"' (now in Sumatra; Görür and Sengör, this volume), or as "North Victoria Land" (now in Burma; Veevers, 1988), or as "Lhasa Block" (Fig. 18A). 

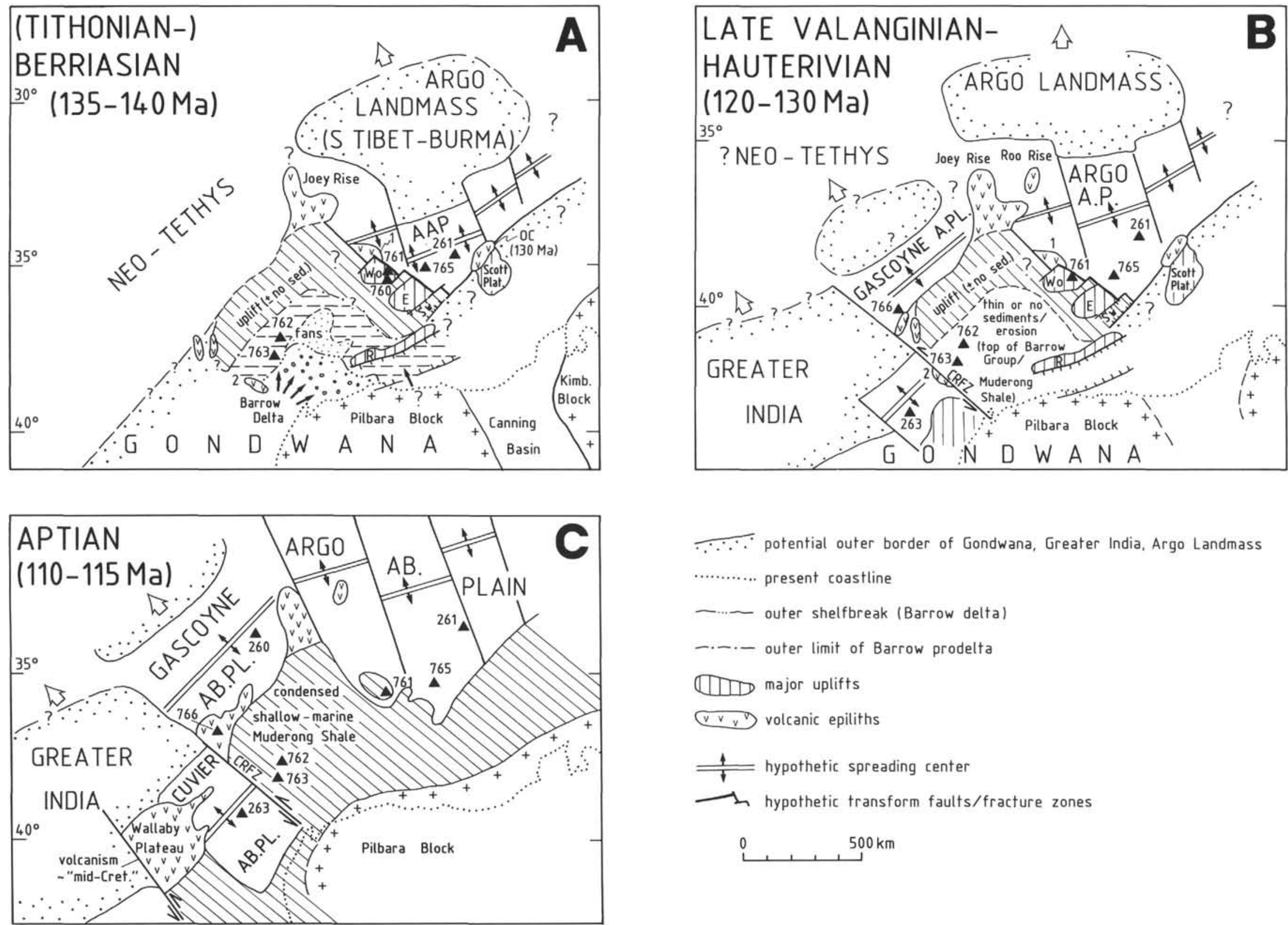

$\because \because \because$ potential outer border of Gondwana, Greater India, Argo Landmass

........... present coastline

— - outer shelfbreak (Barrow delta)

-. - outer limit of Barrow prodelta

(11D) major uplifts

v volcanic epiliths

$\frac{1}{t}$ hypothetic spreading center

In hypothetic transform faults/fracture zones

0 $500 \mathrm{~km}$

Figure 18. Paleogeography of the northwest Australian margin and vicinity during the Tithonian to Berriasian (A), late Valanginian to Hauterivian (B), and Aptian (C). Modified after Barber (1988), Exon et al. (this volume, chapter 1), Kopsen and McGann (1985), Bradshaw et al. (1988), Veevers (1988), Boote and Kirk (1989), Gradstein et al. (1989b), and Boyd et al. (this volume). Paleolatitudes after Ogg et al. (in press). Abbreviations: $\mathrm{AAP}=$ Argo Abyssal Plain, $\mathrm{CRFZ}=\mathrm{Cape}$ Range Fracture Zone, $\mathrm{E}=\mathrm{Emu}$ Plateau, OC $=$ Oates Canyon (western escarpment of Scott Plateau), R = Rankin Platform, Sw $=$ Swan Canyon graben, and Wo $=$ Wombat Plateau (transgressive Berriasian sand and calcisphere/bentonite series); $1=$ Rhaeto-Liassic older volcanics (northern Wombat escarpment) and 2 = mid-Berriasian intrusion (Boyd et al., this volume). 
Alternatively, all of these blocks may be slivers of a single landmass. During the late Valanginian to early Hauterivian, a second continental breakup occurred between "Greater India" and the central Exmouth Plateau that opened the Gascoyne and Cuvier abyssal plains (Fig. 18B).

Tithonian/Berriasian paleogeography is shown in Figure 18A. In the Tithonian, continental breakup was followed by seafloor spreading and rapid subsidence of the Argo Abyssal Plain. This "birth" of a narrow, east-west-trending protoIndian Ocean was witnessed by the deposition of a peculiar suite of hemipelagic "juvenile-ocean sediments" of Tithonian to Neocomian age. Rapid subsidence and the eustatic sealevel rise (138 and $136 \mathrm{Ma}$ according to Haq et al., 1987) caused a major relative sea-level rise, especially at the outer continental margin. On the Wombat Plateau the juvenileocean sediments consist of a transgressive series of condensed, littoral to nearshore sands and shelfal belemnitebearing sandy silts, followed by hemipelagic calcisphere nannofossil chalks alternating with thick bentonite layers (Fig. 18). The low-diversity assemblage of abundant calcispheres, thoracospheres, and belemnites and the isotopic data suggest the absence of true open-ocean conditions. The overpopulation of opportunistic species might be due to restricted circulation and resulting salinity or productivity extremes (Bralower, Keupp, both this volume). Light $\delta^{13} \mathrm{C}$ and somewhat heavy $\delta^{18} \mathrm{O}$ values of the calcisphere-nannofossil chalks are consistent with deposition of these chalks in a highly productive ocean, either an environment with a close connection to the terrestrial carbon reservoir or an upwelling area (Bralower, this volume).

\section{Lithostratigraphic Evolution}

A nearshore siliciclastic to hemipelagic "juvenile"-ocean margin section of (?Tithonian-)Berriasian-Valanginian age, which contained conspicuous lithofacies such as belemniterich sands, calcisphere nannofossil chalks, and bentonite layers, was recovered at Site 761 (Fig. 9C, back pocket). Figure 19 shows a lithostratigraphic column of this juvenileocean margin section. Because of the comparatively poor core recovery in Holes 761B and 761C, von Rad and Thurow (this volume) used the continuous record of the in-situ petrophysical and geochemical properties measured by wireline logs to supplement the cored section. The sequence shown in Figure 19 contains:

1. A 5-m-thick, fining-upward (i.e., deepening upward) condensed section of ferruginous arkosic sand grading into a belemnite-rich sandy silt/clay. This sequence contains the belemnite Belemnopsis $\mathrm{cf}$. jonkeri, which suggests a Berriasian age (Mutterlose, in press). However, according to Challinor (pers. comm., 1990) the belemnites might also be Belemnopsis stolleyi Stevens (1964) of late Tithonian age. Upsection, this sequence shows rapidly increasing natural gamma and decreasing sonic velocity values, and represents a transgressive (?littoral to nearshore), immature sand deposited under high-energy conditions. Apparently, Upper Triassic siliciclastic sediments (quartz, feldspar, chert, volcanic rocks, etc.) exposed in the area of Site 760 on the uplifted Wombat block were reworked to produce this sand. This is another argument for the existence of a paleo-relief of the southern Wombat Plateau during the Middle to Late Jurassic that underwent subaerial erosion. The overlying belemnite-bearing sandy silt/clay was deposited very slowly on a rapidly subsiding shelf.

2. A Berriasian to Valanginian section, about $20 \mathrm{~m}$ thick, dominated by hemipelagic calcisphere nannofossil chalk and marl, intercalated with porcellanite nodule horizons (240-246 mbsf) and six conspicuous bentonite horizons called B1-B6 (Fig. 19). The bentonitic claystones are characterized by very low sonic velocities and gamma-ray/thorium maxima. This sequence contains a low-diversity flora of calcareous dinoflagellate cysts and other nannofossils of late Berriasian to Valanginian age (Keupp; Bralower, both this volume). The water depth during this interval had probably increased by rapid early post-breakup subsidence to bathyal depths (about $200-1000 \mathrm{~m}$ ). This sequence may, in part, correlate with the Haycock Marl of the Muderong Shale (Valanginian to Aptian) in the Dampier Basin, a partly restricted, low-energy offshore marine deposit of the Carnarvon Basin (Hocking et al., 1987).

At Site 760 (Sections 122-760A-9H-6 and 122-760A-10X-1), a very similar section of a 4.4-m-thick variegated, olive-yellow silty claystone to sandstone with Mn nodules and fragments of hydrogenetic Mn crusts was recovered. Here, this section is overlain by a 40 -cm-thick Mn crust and Eocene chalks (De Carlo and Exon, this volume) and underlain by Norian claystones below the post-rift unconformity. Although the claystones and sandstones are mixed with Eocene foraminifers and nannofossils by downhole contamination, a monospecific calcisphere fauna (Orthopithonella $\mathrm{cf}$. deflandrei) suggests a Neocomian to early Aptian (possibly also mid-Cretaceous) age (H. Keupp, pers. comm., 1990). We think that this section can be directly correlated with the ferruginous basal sand of Site 761 .

\section{Bentonites as Indicators of Post-Breakup Volcanism}

Bentonites (smectite-dominated, altered volcanic ash layers) were recovered in the Berriasian to Valanginian hemipelagic sediments of the Wombat Plateau (Site 761, Fig. 19) and compared by von Rad and Thurow (this volume) to coeval bentonites in eupelagic sediments of the adjacent Argo Abyssal Plain (Sites 261 and 765).

A volcaniclastic origin, with dacitic to rhyolitic ash as parent materials, is suggested by the abundance of wellordered montmorillonite, fresh to altered silicic glass shards, volcanogenic minerals (euhedral sanidine, apatite, long-prismatic zircon), and volcanic rock fragments, and by a vitroclastic ultrafabric (smectitized glass shards). Von Rad and Thurow (this volume) distinguish (1) pure smectite bentonites with a white, pink, or light-gray color, a waxy appearance, and a very homogeneous, cryptocrystalline smectite matrix (water-free composition at Site 761: $68.5 \% \mathrm{SiO}_{2}, 19.1 \% \mathrm{Al}_{2} \mathrm{O}_{3}$, $\left.3.3 \% \mathrm{Fe}_{2} \mathrm{O}_{3}, 0.4 \%-1.1 \% \mathrm{Na}_{2} \mathrm{O}, 0.6 \% \mathrm{~K}_{2} \mathrm{O} ; 17 \% \mathrm{H}_{2} \mathrm{O}\right)$ and (2) impure bentonitic claystones containing mixtures of volcanogenic smectite and pyroclastic grains with terrigenous and pelagic components.

Volcanic activity was associated with continental breakup and the rapid subsidence that followed (Fig. 20). Considerably enhanced igneous activity can be expected if the asthenosphere under the Exmouth Plateau was comparatively hot and the overlying lithosphere stretched and thinned during rifting and after the onset of oceanic spreading (White, 1989). Thus, volcanic activity was not only associated with Late Triassic to Early Jurassic syn-rift block-faulting events of the northern Exmouth Plateau (von Rad and Exon, 1983; von Rad et al., 1990), but also with continental breakup and the following rapid subsidence at the continent/ocean boundary during the latest Jurassic to Neocomian. Figure 20 shows the location of the potential volcanic source areas that produced the ash layers.

\section{APTIAN-ALBIAN TRANSGRESSION}

During the late Aptian-Albian(-Cenomanian), the Exmouth Plateau experienced a series of major global transgressions. 


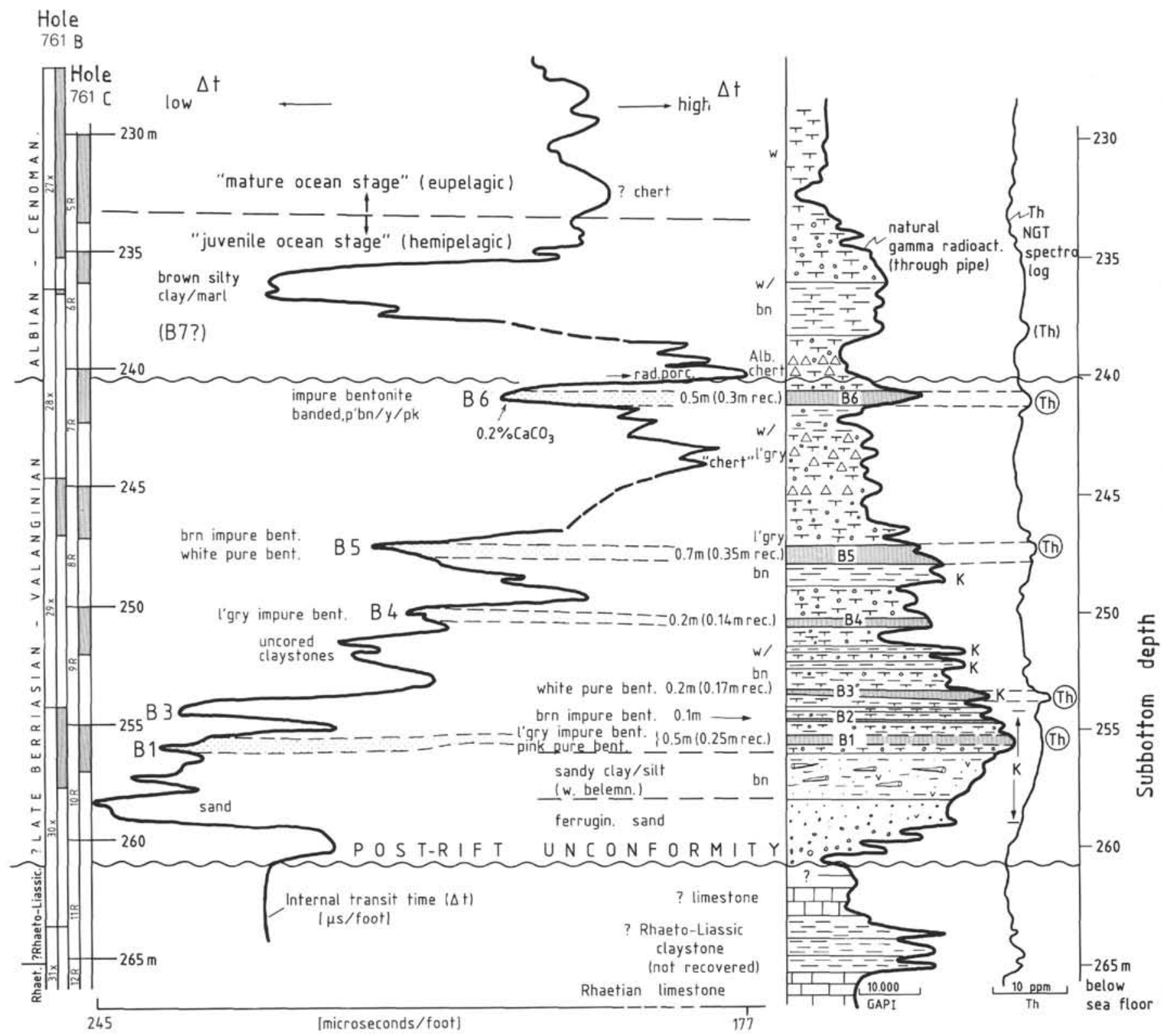

Figure 19. Lithostratigraphy of the Lower Cretaceous section at Site 761 (Wombat Plateau) correlated with wireline logs (from von Rad and Thurow, this volume). Note the good correlation of the six bentonite layers (B1 to B6) and a few uncored claystone intervals with natural gamma-ray maxima, high Th contents, and low-velocity intervals. "Chert" (porcellanite) horizons show the opposite trend (sonic velocity maxima and gamma log minima). Note that due to the limited core recovery (left-hand column) the lithostratigraphic column is largely based on interpretation of the natural gamma-ray tool record.

At Site 761, the late Aptian transgression followed a 20-m.y. hiatus (spanning the latest Valanginian to early Aptian). A similar hiatus was observed in the central Exmouth Plateau at Sites 762 and 763 where continental breakup was dated as late Valanginian to early Hauterivian (Brenner, chapter 31; Boyd et al., both this volume). The early Aptian anoxic ("Selli") event is not documented at Wombat Plateau.

During the Aptian (i.e., after the Greater India-Australia separation) bathyal claystone was deposited on Wombat Plateau, whereas a thin transgressive shallow-marine mudstone sequence accumulated on the central Exmouth Plateau and on the Northwest Shelf (Fig. 18C; see also Exon et al., this volume, chapter 1). At the Wombat Plateau Site 761 nannofossils indicate an Albian to Cenomanian age (Bralower and
Siesser, this volume; P. Čepek, pers. comm., 1990). Hence the Aptian appears to be missing. Radiolarian blooms suggest high fertility (?upwelling), but the deposited radiolarian chalks were later transformed to porcellanites and might be partly equivalent to the Windalia Radiolarite (Blome, this volume).

During the Albian (Exon et al., this volume, chapter 1, their fig. 8D), another major transgression produced a very thin sequence of chalk on the Wombat Plateau, with local porcellanite layers and high zeolite (clinoptilolite) content, apparently from the dissolution of dissolved skeletal opal and reprecipitation of authigenic opal-CT during slow sedimentation. The Albian chalks were probably deposited at a water depth of $>1000 \mathrm{~m}$ and indicate the transition from the hemipelagic "juvenile-ocean" to the eupelagic "mature-ocean" 


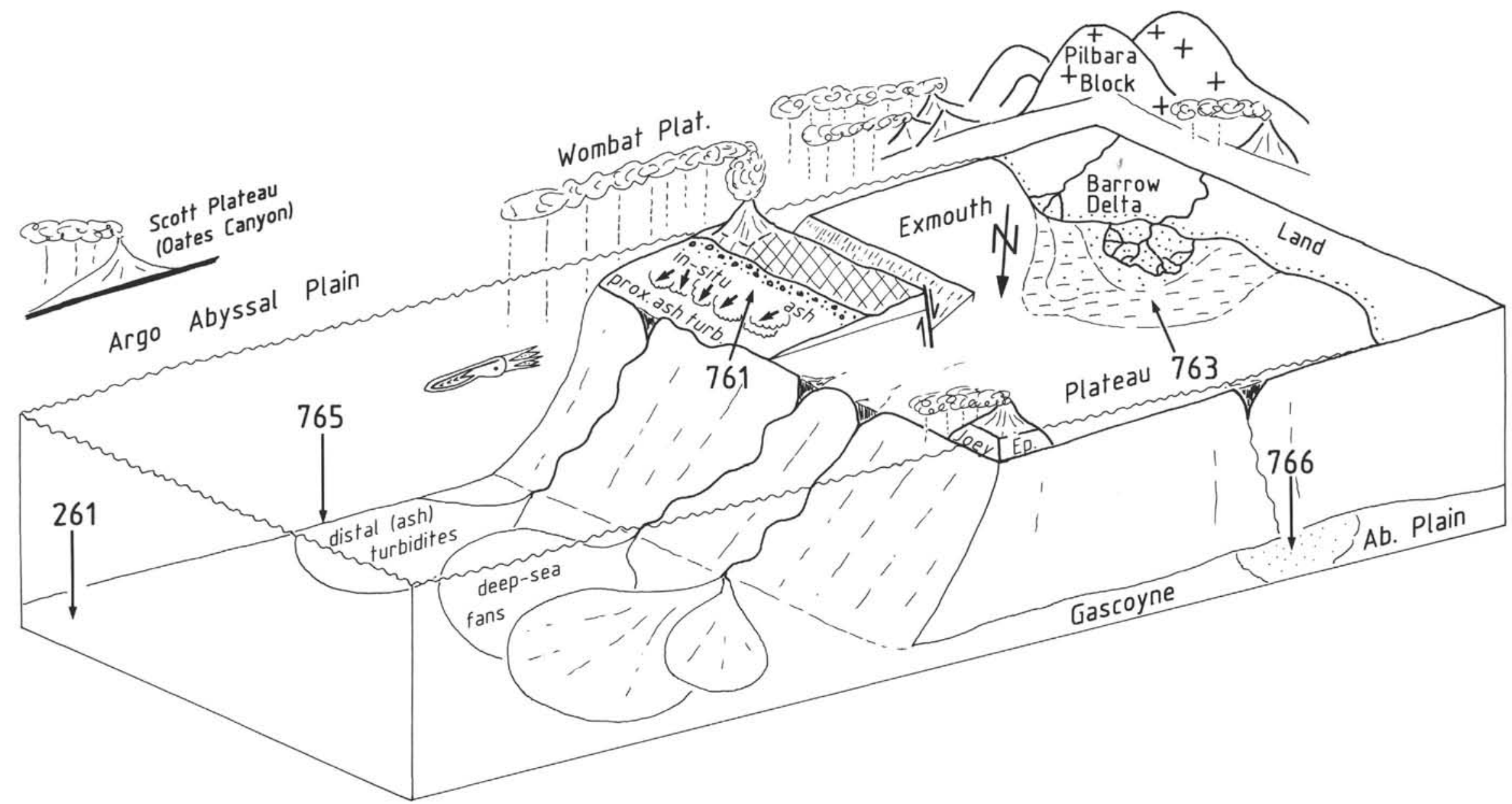

Figure 20. Schematic paleogeographic sketch of the northwest Australian margin during the late Berriasian to Valanginian with location of Sites 761,763 , 765 , and 766 and DSDP Site 261 (from von Rad and Thurow, this volume). Not to scale. Potential volcanic source areas for bentonites are very speculative. 
stage. At the Argo Abyssal Plain Site 765, the opal-CT/quartz transformation boundary was found between Aptian/Albian (opal-CT) and Neocomian (quartz) strata (Compton et al., in press).

\section{MATURE-OCEAN PALEOENVIRONMENT (LATE CRETACEOUS-CENOZOIC)}

The "mature-ocean" stage is characterized by the lack of terrigenous influx and unrestricted thermohaline circulation resulting in pelagic sedimentation in a relatively deep marine environment. By the Turonian-Coniacian, the Wombat Plateau lay in bathyal depths $(500-1000 \mathrm{~m})$, accumulating pure foraminiferal nannofossil chalks. Subsidence continued at a steady pace throughout the Late Cretaceous and early Paleogene, decreasing somewhat in the late early Eocene (around $50 \mathrm{Ma}$ ) probably in response to the initial collision of India with Asia which effected a slowing down of seafloor spreading rates throughout the Indian Ocean (Haq, 1989).

In general, the Late Cretaceous-Paleogene represents an extended period of tectonic quiescence without any record of volcanic activity on the Wombat Plateau, which slowly subsided to its present water depth (2000-2500 m). The Australian continent separated from Antarctica during the Late Cretaceous/ Paleocene and drifted northward from about $40^{\circ} \mathrm{S}$ (Albian) to its present latitude $\left(17^{\circ} \mathrm{S}\right)$.

After the Albian the plateau had apparently subsided sufficiently to avoid the influence of sea-level fluctuations. The Upper Cretaceous section is quite condensed $(60 \mathrm{~m}$ at Site 761 ) and disrupted by four unconformities (Bralower and Siesser, this volume). The eupelagic nannofossil chalk contains foraminifers and Inoceramus fragments. Locally, there are layers or nodules of porcellanite replacing a radiolarianrich chalk. The porcellanite nodules and the presence of authigenic zeolite (clinoptilolite) suggest comparatively productive surface waters (radiolarians) and dissolution of opaline skeletons, followed by diagenetic silica mobilization and reprecipitation as authigenic clinoptilolite or opal-CT. High zeolite concentrations are typical for sections with low sedimentation rates. The porcellanites of Site 761 contain Albian to Cenomanian radiolarians and are intermediate in maturity, as some of the opal-CT of the matrix has already been transformed into diagenetic quartz.

The Cenomanian/Turonian boundary section, an oceanwide anoxic event (Schlanger et al., 1987) that is well documented at Site 763 (Haq et al., this volume), is missing at Site 761 because of a major hiatus between the upper Turonian and lower Albian. At Site 763, we penetrated a carbonate-free black shale layer with up to $25 \%$ total organic carbon (Rullkötter et al., this volume), zeolite-replaced radiolarians, and a lack of bioturbation. This global anoxic event was the result of a major transgression at the beginning of the Turonian which caused a peak of productivity. High production or preservation of planktonic organic matter result in a rising calcite compensation depth and an expanded mid-ocean $\mathrm{O}_{2}$-minimum layer impinging on the upper continental slope. The global oxygen depletion is also experienced in the adjacent Argo Abyssal Plain Site 765, where (because of the much greater paleodepth) the sediments (Section 123-765C-26R-1) are finely laminated and Mn-rich, but lack organic matter and radiolarians (J. Thurow, pers. comm., 1990).

An apparently uninterrupted Cretaceous/Tertiary (K/T) boundary section was recovered from Hole 761C. An iridium anomaly has been recorded in close coincidence with the planktonic turnover at this site, which is also associated with abundance of chromium and $\mathrm{Mg}-\mathrm{Al}-\mathrm{Cr}-\mathrm{Ni}$-rich magnetites (Rocchia et al., this volume). These authors suggest that the terrestrial material was possibly accreted during a number of impacts with multiple small bodies, dispersing most of their mass in the atmosphere. The $\mathrm{K} / \mathrm{T}$ boundary section is biostratigraphically complete (Pospichal and Bralower, this volume): mid-latitude (about $36^{\circ} \mathrm{S}$ ) Cretaceous nannofossils are replaced at the boundary by opportunistic "survivor" species, which in turn are replaced by newly evolved Danian taxa.

Overlying the $\mathrm{K} / \mathrm{T}$ boundary in Hole $761 \mathrm{~B}$, an expanded $(53 \mathrm{~m})$ and apparently complete Paleocene section (with the possible exception of nannofossil Zone NP1) is present (Siesser and Bralower, this volume). The section lent itself to detailed biostratigraphic zonation and also yielded wellpreserved radiolarian assemblages, which is relatively rare in previously drilled deep-sea sites. The fauna may be unique in that it differs somewhat in composition from isolated coeval Paleocene assemblages from Atlantic, Gulf of Mexico, tropical Pacific, and other Indian Ocean sites (Blome, this volume). The chalks contain several intervals with porcellanite nodules, especially in the lower to lower middle Eocene white nannofossil oozes. This concentration of silicified rocks is caused by globally enhanced siliceous plankton productivity and preservation, also well known from the Atlantic and Pacific oceans.

Widespread submarine erosion on the southern Exmouth Plateau begins during the Eocene and is probably related to incipient collisional tectonics at the Australia/Asia plate boundary (Boyd et al., this volume). The global sea-level drop and the onset of erosion by Antarctic Bottom Water (AABW) circulation during the middle Oligocene caused a major hiatus at Sites 761 and 765 spanning the upper Eocene to lower Oligocene. This resulted also in a major canyon cutting event at the steep slopes between the northern Exmouth Plateau and Argo Abyssal Plain. In the lower Miocene rapid deposition of debris flows and calcareous turbidites followed in the southeastern Argo Abyssal Plain (Ludden, Gradstein, et al., 1990), whereas the Wombat Plateau horst remained in a sedimentstarved position.

In the Neogene largely warm-water faunas and floras prevailed on the Wombat Plateau, which had by this time drifted into subtropical latitudes. The generally warm conditions are, however, interrupted by the invasion of coolerwater species during the late middle Miocene, late Miocene, and Pleistocene; this was probably caused by cessation of circum-equatorial bottom-water circulation and increased northward transport of cool surface water by the West Australian Current (Zachariasse, this volume). The Neogene sedimentary record is punctuated by at least two hiatuses in the early and late Miocene, and a major slumping event in the late Miocene (5.8 Ma) and latest Pliocene (1.6 Ma); this may be attributed to the tilting and uplift of the plateau caused by changes in the dynamics of Banda Arc collision and subduction or intraplate stress within the Indian Plate at or after 7.5 $\mathrm{Ma}$ (Zachariasse, this volume; Cloetingh et al., in press).

\section{SUMMARY AND CONCLUSIONS}

\section{Sequence Stratigraphy}

The Upper Triassic depositional sequences recovered from the four Wombat Plateau sites are a composite record of regional tectonics, changes in subsidence rates, changes in the source and rate of sediment supply, climate, and eustatic sea-level fluctuations. Figure 21 shows a generalized crosssection of Wombat Plateau with the correlation of the four Upper Triassic sequences, sequence boundaries (SB), and maximum flooding surfaces (MFS) with the four drill sites. For more detail the reader is referred to Figure 9A-D (back pocket), which shows the generalized lithostratigraphy of all 


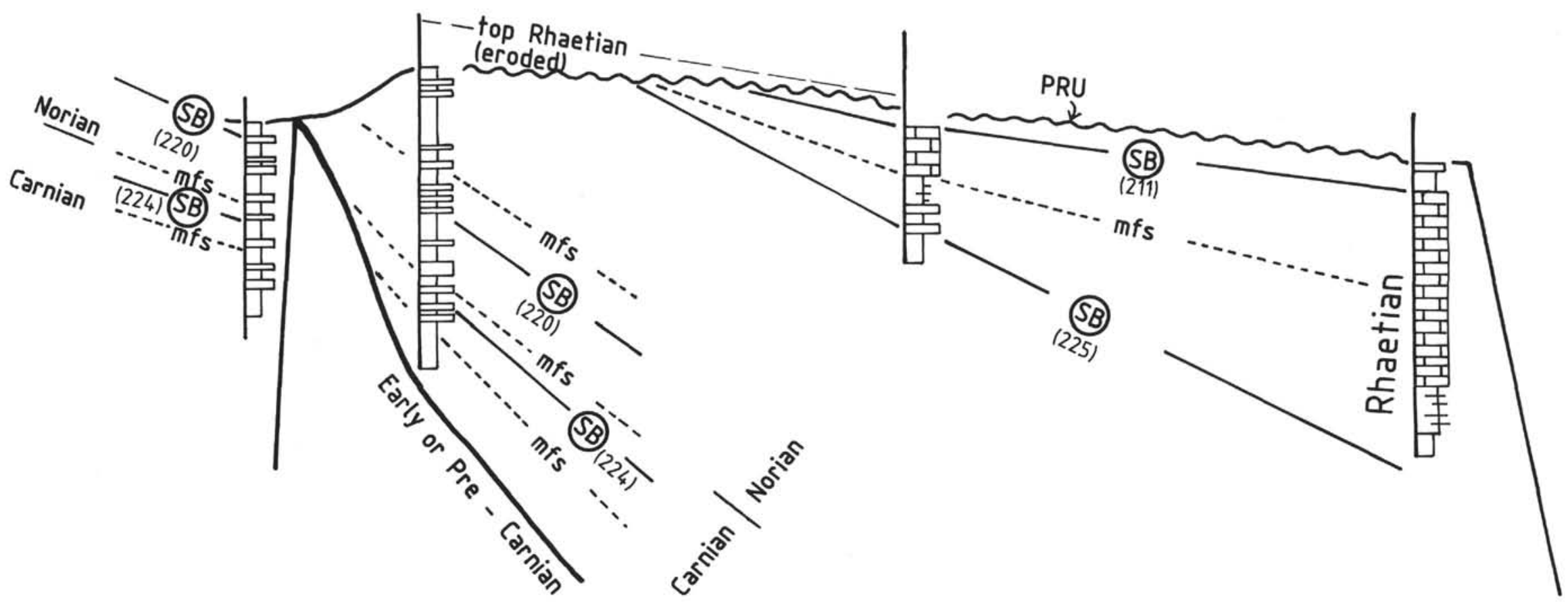

Figure 21. Generalized stratigraphic and structural setting of the Wombat Plateau with simplified lithological columns of Sites 759-761 and 764 (modified from Sarti et al., this volume, with different sequence-stratigraphic interpretation by the present authors). $\mathrm{SB}=$ sequence boundary, $\mathrm{MFS}=$ maximum flooding surface, and PRU $=$ post-rift unconformity. Age (Ma) shown in parentheses. 
four sites together with our paleoenvironmental, tectonic, and sequence-stratigraphic interpretation.

The Carnian-Norian section at Sites 759 and 760 (Fig. 7) is characterized by three sequences separated by two sequence boundaries. The lower SB (late Carnian) is correlated with the 224-Ma SB of the Haq et al. (1987) chart; the upper SB, of mid-Norian age (approximately $220 \mathrm{Ma}$ ), was not included in the global cycle chart of Haq et al. (1987). Each sequence starts with a TST, culminates in a MFS, and leads to an extended HST. In general, we observe an upward-shallowing trend with an evolution from prodelta to delta front, or from subtidal lagoon to delta plain, or from distributary bay to flood plain and coal swamp.

The sequence stratigraphy of the Rhaetian at Sites 761 and 764 (Fig. 8) is characterized by two sequences, one at the Rhaetian/Norian boundary (" $215 \mathrm{Ma}$ ") and one in the uppermost Rhaetian ("211 Ma"). The lower SB is underlain by Norian flood-plain deposits and overlain by "lower" Rhaetian TST sediments that are lagoonal at Site 761. The "middle" Rhaetian represents lagoonal/reefal cycles that belong to the HST; again they are lagoonal-dominated (sub- to intertidal) at Site 761 and reef-dominated (shallow subtidal) at Site 764 . The "uppermost" Rhaetian SB ("211 Ma") documents the first drowning of the Rhaetian carbonate platform, and the overlying more open-marine (subtidal) sediments represent the next TST.

\section{Structural and Stratigraphic Evolution of Wombat Plateau}

Figure 2 shows a schematic cross-section from the northern Exmouth Plateau over Wombat Plateau to the Argo Abyssal Plain and the stratigraphic development of this passive margin sequence from an intracratonic "early-rift" stage (Late Triassic) to "late-rift" or rift-drift transition (Jurassic). The marked post-rift unconformity is underlain by blockfaulted Triassic (and partly Lower to Middle Jurassic) syn-rift sediments and overlain by a thin cover of Cretaceous to Cenozoic post-breakup sediments. The post-rift phase starts with a hemipelagic "juvenile-ocean stage" (Early Cretaceous) which grades into a purely pelagic "mature-ocean stage."

Figure 22 is a graphic summary of the structural and stratigraphic evolution of Wombat Plateau during the past 230 m.y. shown in five time slices. During the Carnian/Norian (Fig. 21A) we observe the northward progradation of seawardthickening fluviodeltaic sediments from the Gondwanan continent with thin intercalations of lagoonal carbonates, riftrelated block-tectonic movements, and volcanism (aborted "early-rift" phase).

The Rhaetian (Fig. 22B) is characterized by an extensive southward transgression of the Tethys sea. This caused a major buildup of reefal and lagoonal carbonates. The carbonate platform was drowned for the first time during the latest Rhaetian ("211 Ma").

At the Callovian/Oxfordian boundary (Fig. 22C-1) the whole area of the northern Exmouth Plateau was uplifted, tilted, and eroded during a major late-rift block-faulting event. This produced the marked post-rift unconformity with nondeposition and/or erosion of Jurassic strata on the uplifted horst, while the downfaulted Wombat half-graben to the south might have been filled by Jurassic (?) sediments, as inferred from seismic evidence. The formation of the PRU predates the Tithonian continental breakup. At the northern flank of the Wombat Plateau horst trachytic to rhyolitic volcanic rocks were extruded during the late Rhaetian to early Liassic. Two interpretations were developed about the evolution of Wombat Plateau between late Rhaetian and Middle Jurassic: (1) the plateau was weakly subsiding (assembling a thin veneer of uppermost Rhaetian to Jurassic strata) and then uplifted and eroded (Fig. 22C-1; Röhl et al., this volume), or uplifted (nondeposition and erosion; Dumont; Borella et al., both this volume); and (2) the Wombat Plateau subsided rapidly during the Jurassic and the drowned carbonate platform experienced no subaerial erosion but rather extreme condensation or nondeposition (Fig. 22C-2; Sarti et al., this volume). The arguments for both hypotheses were discussed and compared in previous sections.

Dumont (this volume) suggests two different, independent rift phases: (1) a "Tethyan" rift phase with tectonic pulses in the Carnian and near the Rhaetian/Hettangian boundary that was responsible for the "Jurassic breakup of northern Gondwanan continental blocks," and (2) an Indo-Australian rift phase (after Callovian?) that caused renewed uplift and erosion before true oceanic crust was formed in the Argo Abyssal Plain.

During the Tithonian to Berriasian (Fig. 22D-1) the Wombat Plateau experienced a second drowning phase that coincided with the rapid subsidence of the newly formed Argo Abyssal Plain, which was mechanically coupled with the Wombat Plateau. This resulted in a major transgression and the deposition of a condensed, deepening-upward sequence of terrigenous to hemipelagic "juvenile-ocean" sediments: littoral arkosic sands, overlain by belemnite-rich sandy mudstones (deeper shelf) and calcisphere-nannofossil chalks, intercalated with thick bentonites. Sarti et al. (this volume and pers. comm., 1990) explain this sequence as a relict sand and a condensed section deposited on a drowned carbonate platform (Fig. 22D-2).

During the Late Cretaceous (post-Albian) (Fig. 22E), Wombat Plateau had subsided to bathyal depths resulting in the slow deposition of eupelagic chalks and oozes ("matureocean stage").

\section{Climatic Evolution}

Changes in the paleolatitude of the Exmouth Plateau area by latitudinal plate-tectonic movements, as derived from paleomagnetic analysis, played a major role in the regional facies development of the northwest Australian margin and the adjacent Tethys Himalaya depositional area (Gradstein and von Rad, in press; Ogg et al., in press). Between the Early Triassic and Rhaetian (-Liassic) the Exmouth Plateau/Tethys Himalaya part of eastern Gondwana drifted northward from temperate mid-latitudes $\left(55^{\circ}-60^{\circ} \mathrm{S}\right)$ to subtropical $\left(25^{\circ}-30^{\circ} \mathrm{S}\right)$ low latitudes (Ogg et al., in press). This resulted in the significant Tethyan influx and buildup of a carbonate platform with flourishing reefs in this region during the Rhaetian (and Liassic). During the Middle Jurassic the continent had again moved southward (to $40^{\circ}-45^{\circ} \mathrm{S}$ ), resulting in more siliciclasticdominated deposition. Northwest Australia remained at temperate mid-latitudes $\left(35^{\circ}-40^{\circ} \mathrm{S}\right)$ from the Oxfordian to Albian. Since the Late Cretaceous, Antarctica rifted from Australia, Australia moved steadily northward to its present subtropical position, and carbonate sedimentation reappeared. In addition, the global climate changed considerably between the Triassic and the Cretaceous.

\section{Subsidence History}

The subsidence or decompacted burial history of a composite Wombat Plateau section (Exon et al., this volume, chapter 1, their fig. 11) is shown in Figure 23. The input parameters to this graph include sediment thicknesses of biostratigraphically dated horizons, biostratigraphic ages for each stratigraphic increment (using the time scale of Haq et al., 1987), measured porosities as a function of lithology and depth for compaction correction, paleowater depth estimates (from litho- and biofacies), and estimated eustatic sea-level 


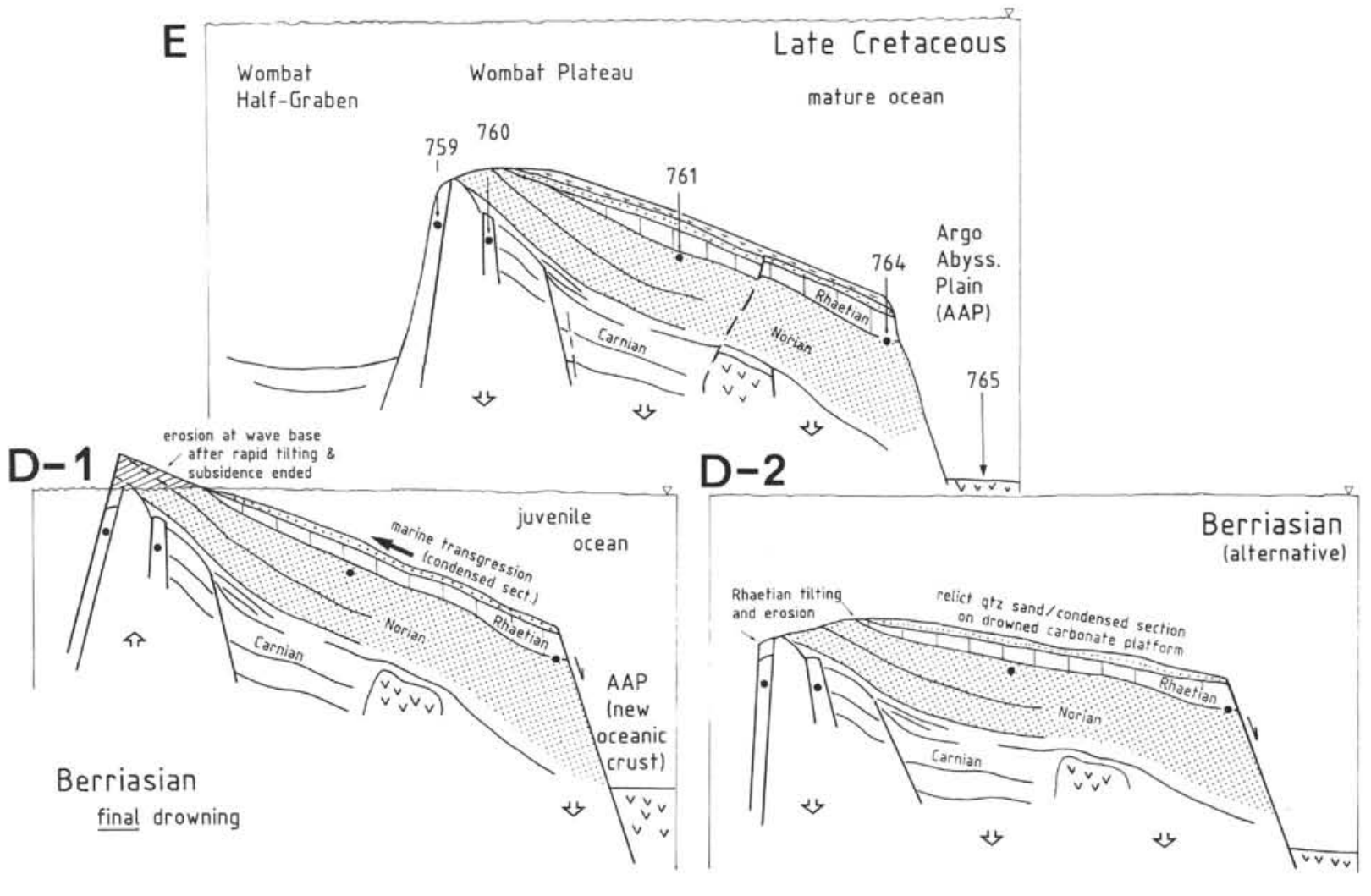

Callov./Oxford.

Jurassic

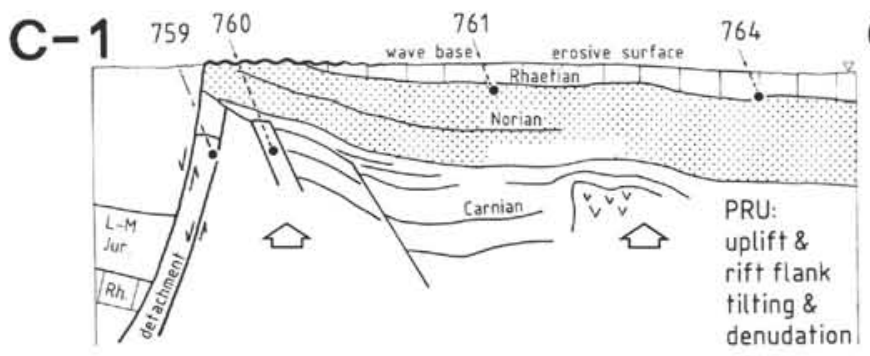

$\mathrm{C}-2$

alternative: drowned platform-nondeposition

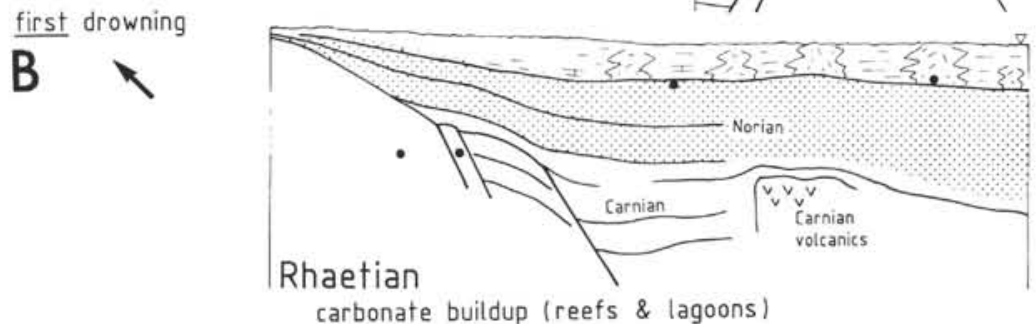

final drowning

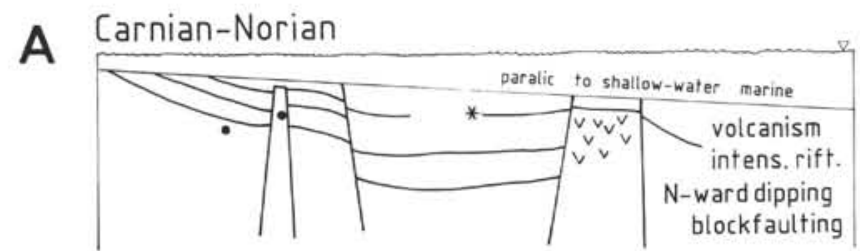

* tect. enhanced condensed section (Carn./Nor. boundary)

Figure 22. Structural evolution of the Wombat Plateau during the past 230 m.y. (modified after von Rad et al., 1989, using data of Röhl et al. and Dumont, both this volume). A. Carnian/Norian boundary (fluviodeltaic siliciclastics). B. Rhaetian (carbonate buildup). C. (1) Callovian/Oxfordian (post-rift unconformity) and (2) Jurassic-alternative interpretation after Sarti et al. (this volume and pers. comm., 1990): thin, condensed carbonate, later eroded. D. (1) Neocomian "juvenile-ocean" stage (after von Rad and Thurow, this volume) and (2) Neocomian: alternative interpretation after Sarti et al. (this volume and pers. comm., 1990). E. Late Cretaceous ("mature-ocean" stage). 


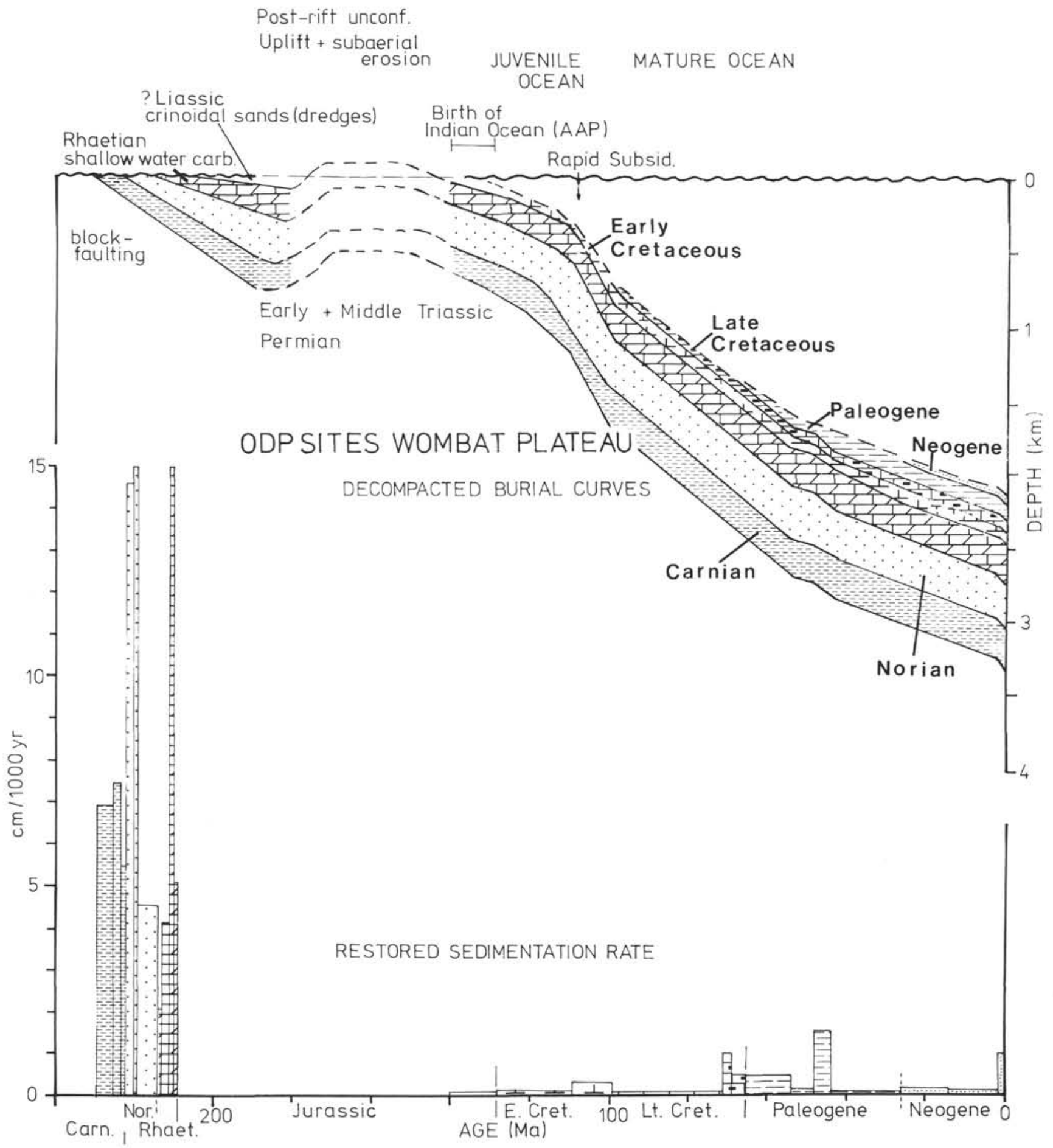

Figure 23. Subsidence history (decompacted burial curves) and sedimentation rates of the Wombat Plateau sites (calculated with the programs BURSUB and DEPOR by Gradstein et al., 1989a). After uplift (post-rift unconformity) in the Middle Jurassic, rapid thermal subsidence submerged the plateau in the Early Cretaceous. Note asymptotically decreasing thermal subsidence rates during the Late Cretaceous to Cenozoic. Sedimentation rates are comparatively high during the Late Triassic early-rift stage and exponentially decrease during the accumulation of the pelagic Cretaceous to Cenozoic sediments. AAP = Argo Abyssal Plain. 
heights (BURSUB program, Gradstein et al., 1989a). The diagram shows also the decompacted sedimentation rates. During the Carnian-Norian we observe several shallowingupward cycles (prodelta to coal swamp); at the Rhaetian/ Norian boundary we see evidence of a global transgression that resulted in carbonate buildup. Sedimentation rates were high during the Late Triassic aborted rifting stage. Drowning of the carbonate platform was followed by subsidence to slightly greater water depths during the Early Jurassic (based on dredge information). After uplift during the Callovian/ Oxfordian and the formation of the post-rift unconformity, the plateau experienced rapid tectonic subsidence, submerging it during the Tithonian to Early Cretaceous. In general, the subsidence rates decreased asymptotically to $<1 \mathrm{~cm} / \mathrm{k}$.y. during the Late Cretaceous to Cenozoic.

\section{Conclusions}

1. The Mesozoic depositional sequences recovered from the old, sediment-starved, rifted margin at the Wombat and Exmouth plateaus (Fig. 24) provide a case study of the dynamic relationship between vertical tectonics (uplift during block-faulting and differential subsidence), climatic changes, changes in the source and rate of siliciclastic input, volcanic activity (early rift and post-breakup), and eustatic sea-level fluctuations. The recovered section provides an excellent example of the interaction of these factors and the depositional response.

2. We have shown the important influence of tectonics during the rift stage and rift-drift transition. From regional geology, seismic stratigraphy, and ODP drilling we know that at least four major tectonic events influenced the evolution of this margin: (1) a rift event near the Carnian/Norian boundary caused by block-faulting (uplift, rapid erosion, and redeposition); (2) a major post-rift unconformity at the Callovian/ Oxfordian, the result of uplift of the outer margin, tilting of the block, and subaerial erosion, which caused a major Jurassic hiatus on the Wombat Plateau horst; (3) a first breakup during the Late Jurassic at the Wombat Plateau, preceded by the opening of the Argo Abyssal Plain (155 Ma), and (4) a second breakup unconformity during the late Valanginian/Hauterivian (M-10) at the southern Exmouth Plateau, coinciding with intense uplift of the southern hinterland and the formation of Gascoyne and Cuvier abyssal plains between Australia and "Greater India." Sediment burial curves provided clues about tectonic events, which caused abrupt changes in the subsidence rates due to the differential thinning of the continental crust of the margin during the early post-breakup history ("non-uniform subsidence").

3. Climatic changes, such as the northward drift of the northwest Australian area to subtropical latitudes during the Rhaetian, favored the buildup of reefal carbonates and terminated the deposition of fluviodeltaic siliciclastics at the outer margin.

4. Changes in the source and rate of siliciclastic sediment input were especially important during rapid fluviodeltaic early-rift sedimentation in the Carnian/Norian. Mississippitype migrating delta lobes in the Carnian/Norian section do not require a fluctuating sea level to explain the frequent alternation of siliciclastic with the "autochthonous" shallowwater carbonate facies in space and time. If there is an excess of siliciclastic sediment supply, this factor may override the eustatic signal (Boyd et al., this volume).

5. The end of the Late Triassic/early Liassic aborted early-rift phase and the Late Jurassic/early Neocomian breakup was accompanied and followed by major pulses of volcanic and volcaniclastic activity of felsic to intermediate composition. The post-breakup volcanism can be explained by the upwelling of hot asthenosphere during the stretching and thinning of the overlying lithosphere, and the rapid subsidence of the newly formed ocean basins.

6. Eustacy seems to have played a significant role in generating the depositional sequences in the Late Triassic (Fig. 8) and Early Cretaceous (Haq et al., this volume, their fig. 8). The Upper Triassic shallow-water carbonates are thought to bear a strong eustatic signal. We recognized several sequence boundaries in the Late Triassic that are little disturbed by tectonics. However, separating the tectonic signal from eustatic events is not straightforward, especially if the tectonic development is as complex as at the Wombat Plateau during the Late Triassic to Jurassic. A good argument in favor of global sea-level fluctuations is the excellent correlation of two major sequence boundaries and of the resulting conspicuous facies changes between the eastern Tethys (northwest Australia) and the well-studied western Tethyan outcrops in the western, northern, and southern Alps. We found an SB close to the Norian/Rhaetian boundary. A major SB of the same age, the "early Rhaetian transgression," is known from the Alps. This is an argument in favor of a global eustatic origin for this event that fits well with the $215-\mathrm{Ma}$ SB of the Haq cycle chart. A similar interpretation can be used for the "latest Rhaetian drowning event" that is also observed in the Alps and might be correlated with the 212-Ma SB of Haq et al. (1987).

Although global synchronism of third-order cycles can also be explained by intraplate deformation that reflects high levels of regional stress during major plate reorganizations (Cloetingh et al., in press), we favor global eustasy as the main factor responsible for producing these Late Triassic sequence boundaries. At other times in the Late Triassic the tectonic signal is mixed with the eustatic signal to produce the preserved stratigraphic record. In the Jurassic the tectonic events completely overrode eustasy and wiped out the stratigraphic record.

\section{ACKNOWLEDGMENTS}

We are grateful to all members of the shipboard scientific parties of ODP Legs 122 and 123 for the excellent cooperation on board, the free exchange of data after the cruises, and their scientific contribution to the success of both legs. We appreciate especially the detailed discussions with Ron Boyd (Halifax), Tim Bralower (Chapel Hill), Wolfram Brenner (Kiel), Thierry Dumont (Grenoble), Felix Gradstein (Dartmouth), Jörg Mutterlose (Hannover), Ursula Röhl (Hannover), and Jürgen Thurow (Tübingen). Ursula Röhl assisted generously with the compilation and reduction of the enormous data set and with the preparation and drafting of the figures. Technical assistance (drafting and typing) was given by H. Karmann, E. Brockmann, and E. Müller. U. von Rad acknowledges financial support by the Deutsche Forschungsgemeinschaft (Bonn; DFG grants Ra 191-10/2-4). The manuscript was reviewed by Timothy Bralower, Gerhard Einsele (Tübingen), Ursula Röhl, Felix Gradstein, Barry Willcox (Canberra), and especially Thierry Dumont. We are very grateful for a great number of helpful critical comments.

\section{REFERENCES}

Audley-Charles, M. G., 1988. Evolution of southern margin of Tethys (North Australian region) from early Permian to late Cretaceous. In Audley-Charles, M. G., and Hallam, A. (Eds.), Tethys and Gondwana. Geol. Soc. Spec. Publ. London, 37:79-100.

Barber, P. M., 1988. The Exmouth Plateau deep water frontier: a case history. In Purcell, P. G., and Purcell, R. R. (Eds.), The North West Shelf, Australia: Proc. Pet. Expl. Soc. Aust. Symp., 173-187. 
Boillot, G., Winterer, E. L., Meyer, A. W., et al., 1987. Proc. ODP, Init. Repts., 103: College Station, TX (Ocean Drilling Program).

Boote, D.R.D., and Kirk, R. B., 1989. Depositional wedge cycles on evolving plate margin, western and northwestern Australia. AAPG Bull., 73:216-243.

Bown, P. R., and Dumoulin, J. A., in press. Sedimentology, micropaleontology and depositional environments of basal sequences (Upper Jurassic to Lower Cretaceous) on the Argo Abyssal Plain. In Gradstein, F. M., Ludden, J. N., et al., Proc. ODP, Sci. Results, 123: College Station, TX (Ocean Drilling Program).

Bradshaw, R. T., Yeates, A. N., Beynon, R. M., Brakel, A. T., Langford, R. P., Totterdell, J. M., and Yeung, M., 1988. Paleogeographic evolution of the North West Region. In Purcell, P. G., and Purcell, R. R. (Eds.) The North West Shelf, Australia: Proc. Pet. Expl. Soc. Aust. Symp., 29-54.

Cloetingh, S., Stein, C., Reemst, P., Gradstein, F. M., Williamson, P. E., Exon, N. F., and von Rad, U., in press. The relationship between continental margin stratigraphy, deformation, and intraplate stresses for the Indo-Australian region. In Gradstein, F. M., Ludden, J. N., et al., Proc. ODP, Sci. Results, 123: College Station, TX (Ocean Drilling Program).

Compton, J. S., Mallinson, D., Netranatawong, T., and Locker, S., in press. Regional correlation of mineralogy and diagenesis of sediment from the Exmouth Plateau and Argo Basin, Northwestern Australian continental margin. In Gradstein, F. M., Ludden, J. N., et al., Proc. ODP, Sci. Results, 123: College Station, TX (Ocean Drilling Program).

Dewey, J. F., 1988. Lithospheric stress, deformation and tectonic styles: the disruption of Pangaea and the closure of Tethys. In Audley-Charles, M. G., and Hallam, A. (Eds.), Tethys and Gondwana. Geol. Soc. Spec. Publ. London, 37:23-40.

Einsele, G., 1982. General remarks about the nature, occurrence, and recognition of cyclic sequences (periodites). In Einsele, G., and Seilacher, A. (Eds.), Cyclic and Event Stratification: Berlin (Springer), 3-7.

Einsele, G., and von Rad, U., 1979. Facies and paleoenvironment of Lower Cretaceous sediments at DSDP Site 397 and in the Aaiun Basin (Northwest Africa). In von Rad, U., Ryan, W.B.F., et al., Init. Repts DSDP, 47 (Pt. 1): Washington (U.S. Govt. Printing Office), 559-577.

Exon, N. F., von Rad, U., and von Stackelberg, U., 1982. The geological development of the passive margins of the Exmouth Plateau off northwest Australia. Mar. Geol., 47:131-152.

Exon, N. F., and Willcox, J. B., 1978. Geology and petroleum potential of the Exmouth Plateau area off Western Australia. AAPG Bull. 62:40-72.

1980. The Exmouth Plateau: stratigraphy, structure and petroleum geology. Bull. Bur. Miner. Resour. Geol. Geophys. Aust., No. 199.

Exon, N. F., and Williamson, P. E., 1988. Preliminary post-cruise report, Rig Seismic Research Cruises 7 \& 8: sedimentary basin framework of the northern and western Exmouth Plateau. Bur. Min. Resour. Aust. Rec., 1988/30.

Exon, N. F., Williamson, P. E., von Rad, U., Haq, B. U., and O'Connell, S., 1989. Ocean drilling finds Triassic reef play off NW Australia. Oil \& Gas Journal, 87:46-52.

Falvey, D. A., 1974. The development of continental margins in plate tectonic theory. APEA J., 14:95-106.

Fisher, R. V., and Schmincke, H.-U., 1984. Pyroclastic Rocks: New York (Springer-Verlag).

Fullerton, L. G., Sager, W. W., and Handschumacher, D. W., 1989. Late Jurassic-Early Cretaceous evolution of the eastern Indian Ocean adjacent to Northwest Australia. J. Geophys. Res., 94:2937-2953.

Gradstein, F. M., Fearon, J. M., and Huang, Z., 1989a. BURSUB and DEPOR version 3.50-two FORTRAN 77 programs for porosity and subsidence analysis. Open-File Rep.-Geol. Surv. Can., 1283:1-10.

Gradstein, F. M., Gibling, M. R., Jansa, L. F., Kaminski, M. A., Ogg, J. G., Sarti, M., Thurow, J. W., von Rad, U., and Westermann, G.E.G., 1989b. Mesozoic Stratigraphy of Thakkhola, Central Nepal (Lost Ocean Expedition). Spec. Rep. Cent. Mar. Geol. Dalhousie Univ., 1:1-115.

Gradstein, F. M., and von Rad, U., in press. Stratigraphic evolution of Mesozoic continental margin and oceanic sequences, NW
Australia and N. Himalayas. In Davies, T. A., Meyer, A., and Wise, S. W., Jr. (Eds.), The Evolution of Mesozoic and Cenozoic Continental Margins. Spec. Publ. Soc. Econ. Paleontol. Mineral.

Haq, B. U., 1989. Geological evolution of the Indian Ocean with special reference to the Arabian Sea. In Thompson, M. F. (Ed.), Marine Science of the Arabia Sea. Am. Inst. Biol. Sci., 9-35. 1991. Sequence stratigraphy, sea-level change, and significance for the deep sea. Spec. Publ. Int. Assoc. Sedimentol., $12: 1-36$.

Haq, B. U., Hardenbol, J., and Vail, P. R., 1987. Chronology of fluctuating sea levels since the Triassic. Science, 235:1156-1167. 1988. Mesozoic and Cenozoic chronostratigraphy and cycles of sea-level change. In Wilgus, C., et al., (Eds.), Sea-Level Change-An Integrated Approach. Soc. Econ. Paleontol. Mineral. Spec. Publ., 42:71-108.

Haq, B. U., von Rad, U., O'Connell, S., et al., 1990. Proc. ODP, Init. Repts., 122: College Station, TX (Ocean Drilling Program).

Heirtzler, J. R., Cameron, P., Cook, P. J., Powell, T., Roeser, H. A., Sukardi, S., and Veevers, J. J., 1978. The Argo Abyssal Plain. Earth Planet. Sci. Lett., 41:21-31.

Hocking, R. M., Moors, H. T., and van der Graaff, W.J.E., 1987. The geology of the Carnarvon Basin, Western Australia. Bull.-Geol. Surv. West. Aust., No. 133.

Hooper, P. R., 1990. The timing of crustal extension and the eruption of continental flood basalts. Nature, 345:246-249.

Kaminski, M. A., Baumgartner, P. O., Bown, P. R., Haig, D. W., McMinn, A., Moran, M. J., Mutterlose, J., and Ogg, J. G., in press. Magnetobiostratigraphic synthesis of Ocean Drilling Program Leg 123: Site 765 and 766 (Argo Abyssal Plain and lower Exmouth Plateau). In Gradstein, F. M., Ludden, J. N., et al., Proc. ODP, Sci. Results, 123: College Station, TX (Ocean Drilling Program).

Kendall, C.G.St.C., and Schlager, W., 1981. Carbonates and relative changes in sea level. Mar. Geol., 44:181-212.

Kent, D. V., and Gradstein, F. M., 1986. A Jurassic to Recent chronology. In Tucholke, B. E., and Vogt, P. R. (Eds.), The Geology of North America: The Western Atlantic Region. Geol. Soc. Am. DNAG Ser., 1:45-50.

Klootwijk, C. T., and Bingham, D. K., 1980. The extent of Greater India III. Palaeomagnetic data from the Tibetan Sedimentary Series, Thakkhola Region, Nepal Himalaya. Earth Planet. Sci. Lett., 51:381-405.

Kopsen, E., and McGann, G., 1985. A review of the hydrocarbon habitat of the eastern and central Barrow-Dampier sub-basin, Western Australia. APEA J., 25:154-175.

Larson, R. L., 1975, Late Jurassic sea-floor spreading in the eastern Indian Ocean. Geology, 3:69-71.

Ludden, J. N., and Dionne, B., in press. The geochemistry of oceanic crust at the onset of rifting in the Indian Ocean. In Gradstein, F. M., Ludden, J. N., et al., Proc. ODP, Sci. Results, 123: College Station, TX (Ocean Drilling Program).

Ludden, J. N., Gradstein, F. M., et al., 1990. Proc. ODP, Init. Repts., 123: College Station, TX (Ocean Drilling Program).

Markl, R. G., 1978. Further evidence for the Early Cretaceous breakup of Gondwanaland off Southwestern Australia. Mar. Geol., 26:41-48.

Mutter, J. C., Larson, R. L., and Northwest Australia Study Group, 1989. Extension of the Exmouth Plateau, offshore northwestern Australia: deep seismic reflection/refraction evidence for simple and pure shear mechanisms. Geology, 17:15-18.

Mutterlose, J., in press. Early Cretaceous belemnites from the East Indian Ocean and their paleobiogeographic implications. In Gradstein, F. M., Ludden, J. N., et al., Proc. ODP, Sci. Results, 123: College Station, TX (Ocean Drilling Program).

Ogg, J. G., Kodama, K. and Wallick, B., in press. Lower Cretaceous magnetostratigraphy and paleolatitudes off NW Australia (ODP Site 765 and DSDP Site 261, Argo Abyssal Plain, and ODP Site 766, Gascoyne Abyssal Plain). In Gradstein, F. M., Ludden, J. N., et al., Proc. ODP, Sci. Results, 123: College Station, TX (Ocean Drilling Program).

Piller, W., 1976. Fazies und Lithostratigraphie des gebankten Dachsteinkalkes (Obertrias) am Nordrand des Toten Gebirges (Süd-Grünau/Almtal, Oberösterreich). Mitt. Ges. Geol. Bergbaustud. Osterr., 23:113-152. 
Powell, C. McA., Roots, S. R., and Veevers, J. J., 1988. Pre-breakup continental extension in East Gondwanaland and the early opening of the eastern Indian Ocean. Tectonophysics, 155:261-283.

Quilty, P. G., 1981. Early Jurassic foraminifera from the Exmouth Plateau, western Australia. J. Paleontol., 55:985-995.

Schlanger, S. O., Arthur, M. A., Jenkyns, H. C., and Scholle, P. A., 1987. The Cenomanian-Turonian Oceanic Anoxic Event, I Stratigraphy and distribution of organic carbon-rich beds and the marine $\delta^{13} \mathrm{C}$ excursion. In Brooks, J., and Fleet, A. J. Marine Petroleum Source Rocks. Geol. Soc. Spec. Publ. London, 24:347375.

Sengör, A.M.C., 1985. The story of Tethys: how many wives did Okeanos have? Episodes, 8:3-12.

Sengör, A.M.C., Altiner, D., Cin, A., Ustaömer, T., and Sü, K. J., 1988. Origin and assembly of the Tethyside orogenic collage at the expense of Gondwana Land. In Audley-Charles, M. G., and Hallam, A. (Eds.), Gondwana and Tethys. Geol. Soc. Spec. Publ. London, 37:119-181.

Stanton, R. J., Jr., and Flügel, E., 1989. Problems with reef models: the Late Triassic Steinplatte "reef" (Northern Alps, Salzburg/ Tyrol, Austria). Facies, 20:1-138.

Veevers, J. J., 1988. Morphotectonics of Australia's north-western margin: a review. In Purcell, P. G., and Purcell, R. R. (Eds.), The North West Shelf, Australia: Proc. Pet. Expl. Soc. Aust. Symp., 19-27.

Veevers, J. J., Heirtzler, J. R., et al., 1974. Init. Repts. DSDP, 27: Washington (U.S. Govt. Printing Office).

von Rad, U., and Exon, N. F., 1983. Mesozoic-Cenozoic sedimentary and volcanic evolution of the starved passive continental margin off northwest Australia. In Watkins, J. S., and Drake, C. L. (Eds.), Studies in Continental Margin Geology: AAPG Mem., 34:253281.

von Rad, U., Schott, M., Exon, N. F., Mutterlose, J., Quilty, P., and Thurow, J., 1990. Petrography and microfacies of Mesozoic sediments and volcanic rocks, dredged from the northern Exmouth Plateau during Rig Seismic-56 Cruise (1986). BMR J. Aust. Geol. Geophys., 11:449-476. von Rad, U., Thurow, J., Haq, B. U., Gradstein, F., Ludden, J. and the ODP Leg 122/123 shipboard scientific parties, 1989. Triassic to Cenozoic evolution of the NW Australian continental margin and the birth of the Indian Ocean (preliminary results of ODP Legs 122 and 123). Geol. Rundsch., 78:1189-1210.

von Stackelberg, U., Exon, N. F., von Rad, U., Quilty, P., Shafik, S., Beiersdorf, H., Seibertz, E., and Veevers, J. J., 1980. Geology of the Exmouth and Wallaby Plateaus off northwest Australia: sampling of seismic sequences. BMR J. Aust. Geol. Geophys., 5:113140.

White, R. S., 1989. Volcanism and igneous underplating in sedimentary basins and at rifted continental margins. In Price, R. A. (Ed.), Origin and Evolution of Sedimentary Basins and Their Energy and Mineral Resources. IUGG Geophys. Monogr. 48, 3:125-127.

White, R. S., and McKenzie, D. P., 1989. Magmatism at rift zones: the generation of volcanic continental margins and flood basalts. $J$. Geophys. Res., 94:7685-7729.

Wilgus, C. K., Posamentier, H., Ross, C. A., and Kendall, C.G.St.C. (Eds.), 1988. Sea Level Changes: an Integrated Approach. Spec. Publ. Soc. Econ. Paleontol. Min., No. 42.

Willcox, J. B., and Exon, N. F., 1976. The regional geology of the Exmouth Plateau. APEA J., 16:1-11.

Williamson, P. E., Exon, N. F., Haq, B. U., von Rad, U., O'Connell, S., and Leg 122 Shipboard Scientific Party, 1989. A Northwest Shelf Triassic reef play: results from ODP Leg 122. APEA J., 29:328-344.

Zankl, H., 1971. Upper Triassic facies in the Northern Limestone Alps. In Müller, G. (Ed.), Sedimentology of Parts of Central Europe, Guidebook: Frankfurt (Kramer), 147-185.

Date of initial receipt: 10 October 1990

Date of acceptance: 4 March 1991

Ms 122B-181 


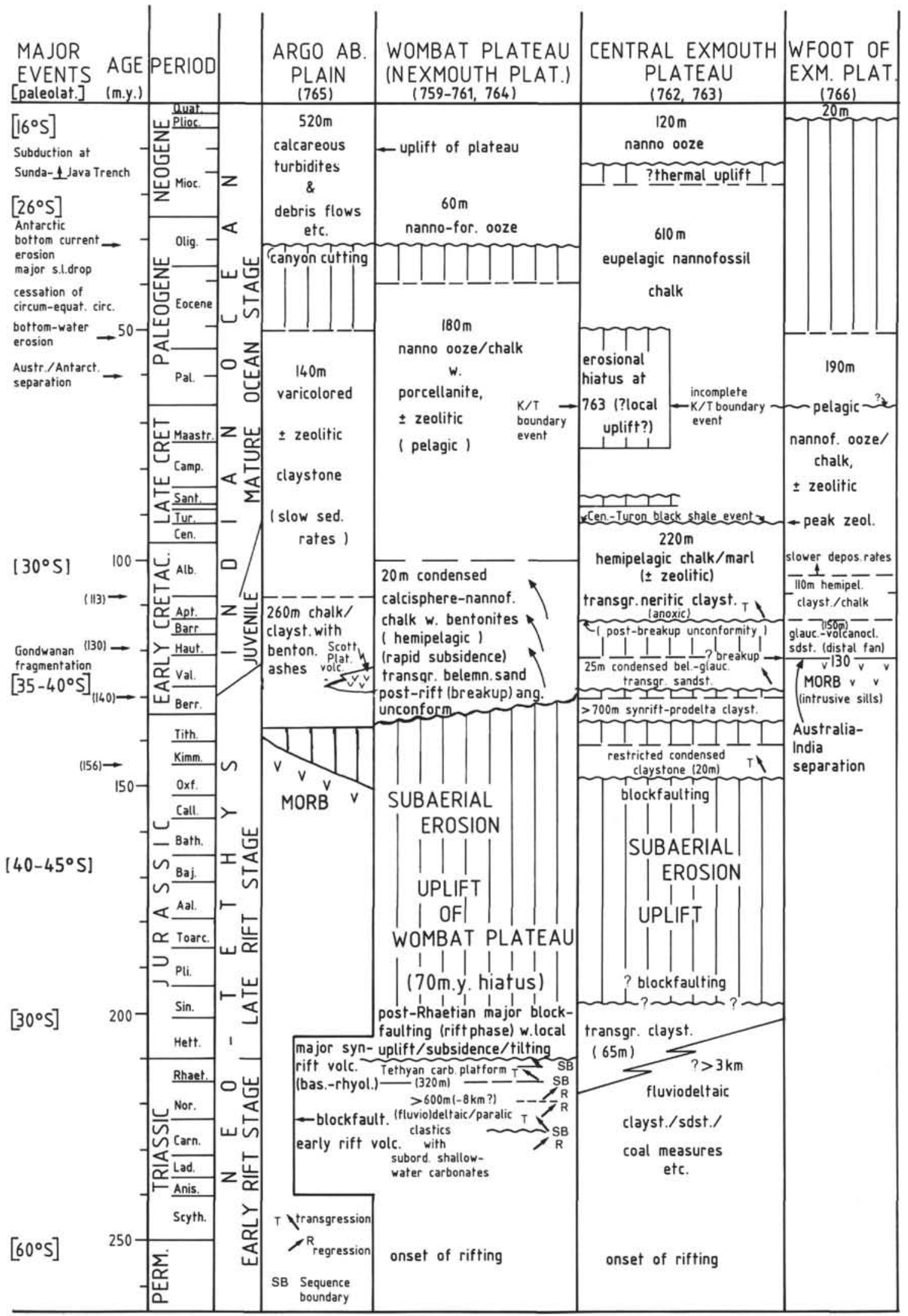

Figure 24. Summary of structural and paleoenvironmental evolution of Leg 122 and 123 sites during the past $250 \mathrm{~m} . \mathrm{y}$. (modified from von Rad et al., 1989). 